Review

\title{
The Role of Nuclear Bodies in Gene Expression and Disease
}

\section{Marie Morimoto and Cornelius F. Boerkoel *}

Department of Medical Genetics, Child \& Family Research Institute, University of British Columbia, Vancouver, BC V5Z 4H4, Canada; E-Mail: mmorimoto@cfri.ca

* Author to whom correspondence should be addressed; E-Mail: nboerkoel@cfri.ca; Tel.: +1-604-875-2157; Fax: +1-604-875-2376.

Received: 15 May 2013; in revised form: 13 June 2013 / Accepted: 20 June 2013 /

Published: 9 July 2013

\begin{abstract}
This review summarizes the current understanding of the role of nuclear bodies in regulating gene expression. The compartmentalization of cellular processes, such as ribosome biogenesis, RNA processing, cellular response to stress, transcription, modification and assembly of spliceosomal snRNPs, histone gene synthesis and nuclear RNA retention, has significant implications for gene regulation. These functional nuclear domains include the nucleolus, nuclear speckle, nuclear stress body, transcription factory, Cajal body, Gemini of Cajal body, histone locus body and paraspeckle. We herein review the roles of nuclear bodies in regulating gene expression and their relation to human health and disease.
\end{abstract}

Keywords: nuclear bodies; transcription; gene expression; genome organization

\section{Introduction}

Gene expression is a multistep process that is vital for the development, adaptation and survival of all living organisms. Regulation of gene expression occurs at the level of transcription, RNA processing, RNA export, translation and protein degradation [1-3]. The nucleus has the ability to modulate gene expression at each of these levels. How the nucleus executes this regulation is gradually being dissected. Of particular interest for this review is the spatial relationship between genes and the proteins and non-coding RNAs that regulate their expression. Specifically, are the regulatory components randomly dispersed throughout the nucleus or concentrated within regions?

Part of the answer lies in the compartmentalization of the nuclear space into nuclear bodies of specific functions. Nuclear bodies are broadly defined as morphologically distinct regions within the 
nucleus; they are distinguishable from their surroundings by techniques, such as transmission electron microscopy, differential interference contrast microscopy and immunofluorescent detection of proteins that localize to a nuclear body of interest. Similar to conventional cytoplasmic organelles, nuclear bodies are distinct local environments of unique functions (Figure 1). Nuclear bodies include the nucleolus, the nuclear speckle, the nuclear stress body, the transcription factory, the Cajal body, the Gemini of Cajal body, the histone locus body and the paraspeckle. Immunofluorescent images of these nuclear bodies can be viewed in the Nuclear Protein Database (http://npd.hgu.mrc.ac.uk). The diverse mechanisms of gene regulation associated with nuclear bodies add another dimension to our understanding of gene regulation.

Figure 1. Diagram summarizing the role of nuclear bodies in gene expression. Abbreviations: A-to-I; adenosine to inosine; HCC, histone cleavage complex; HS, heat shock; HSF1, heat shock factor 1; i, inosine; Me, 2'-O-methylation; Pol, RNA polymerase; pre-mRNA, precursor messenger RNA; pre-snRNA, precursor small nuclear RNA; rDNA, ribosomal DNA; Sat III DNA, satellite III DNA; scaRNP, small Cajal body-specific ribonucleoprotein; SMN, survival of motor neuron complex; snRNP, small nuclear ribonucleoprotein; Ub, ubiquitin; $\Psi$, pseudouridylation.
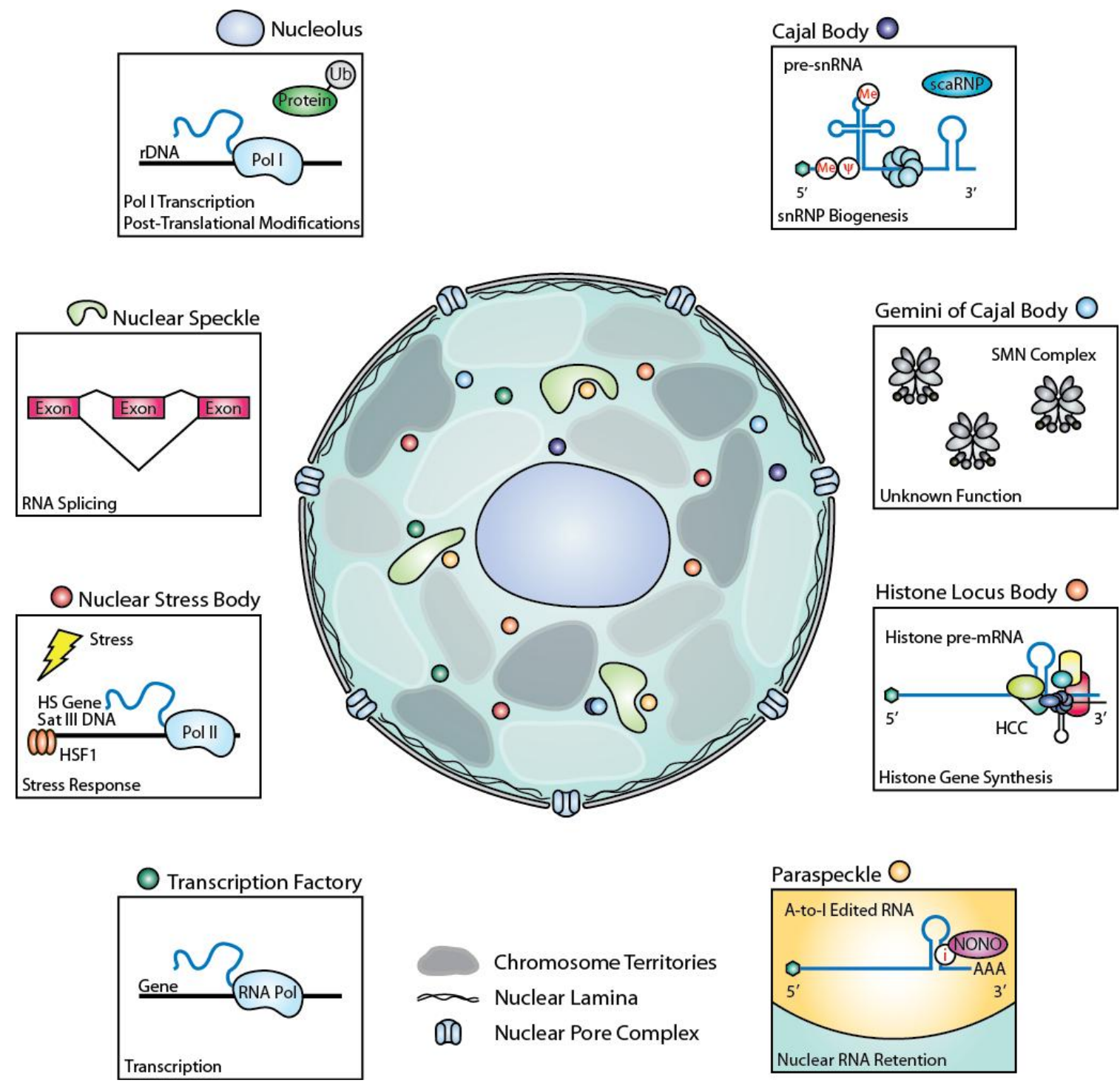


\section{Nuclear Bodies and Mechanisms of Gene Expression}

In this review, we focus on the role of nuclear bodies in gene regulation and discuss human diseases associated with mutations in genes encoding for key components. A review of the perinucleolar compartment is deferred, since it has so far only been identified in cancerous cells, and its relevance to general biology remains unclear. Additionally, although the promyelocytic leukemia (PML) body, the clastosome, the cleavage body, the Oct1/PTF/transcription (OPT) domain, the polymorphic interphase karyosomal association (PIKA) domain and the polycomb group (PcG) body contribute to the regulation of gene expression $[4,5]$, these are not reviewed, because of the limited available information.

\subsection{Nucleolus}

\subsubsection{Discovery}

The nucleolus is one of the most prominent and clearly visible structures in the nucleus. Described by the anatomist Rudolf Wagner in 1835 and by the physiologist Gabriel Valentin the following year, the nucleolus has fascinated scientists for decades [6,7]. Though initially characterized as the major center for ribosome biogenesis [8], it has become increasingly apparent that the nucleolus is a multifunctional nuclear body that also participates in mitosis, cell cycle regulation, DNA replication, DNA repair, ribonucleoprotein (RNP) biogenesis and the stress response [9-11].

\subsubsection{Key Components}

The nucleolus is composed of a fibrillar center surrounded by dense fibrillar and granular components. Among the several hundreds of proteins found in the nucleolus, there are proteins for ribosomal biogenesis, chromatin structure and messenger RNA (mRNA) metabolism, as well as ribosomal proteins, chaperones, translation factors and many others of unknown function [12,13]. These proteins include (1) the phosphoproteins, nucleophosmin and nucleolin, (2) the core members of the box C/D small nucleolar RNP (snoRNP) complex (fibrillarin, NHP2-like protein 1 (NHP2L1), nucleolar protein 56 (NOP56) and nucleolar protein 58 (NOP58)), (3) the core members of the H/ACA snoRNP complex (dyskerin, GAR1, NHP2 and nucleolar protein 10 (NOP10)), (4) the protein chaperone nucleolar phosphoprotein $140 \mathrm{kDa}$ (NOPP140), (5) RNA Polymerase I (RNA Pol I), and (6) proteins of the $40 \mathrm{~S}$ and $60 \mathrm{~S}$ ribosomal subunits (Table 1). Approximately 700 nucleolar proteins have now been identified and catalogued in the Nucleolar Proteome Database (http://www.lamondlab.com/NOPdb/). RNA members include the box C/D and H/ACA small nucleolar RNAs (snoRNAs); these are incorporated into the snoRNPs that process precursor ribosomal RNA (pre-rRNA) (Table 1).

\subsubsection{Functions of Key Components}

Most proteins in the nucleolus participate in ribosomal RNA (rRNA) transcription and pre-rRNA processing [12,13] (Table 1). Nucleophosmin is a multifunctional chaperone involved in ribosome biogenesis and transport [14], and nucleolin is involved in RNA Pol I transcription and pre-rRNA processing $[15,16]$. The box $\mathrm{C} / \mathrm{D}$ and H/ACA snoRNP complexes process pre-rRNA through the 
post-transcriptional modifications, 2'-O-methylation and pseudouridylation, respectively [17]. NOPP140 likely functions as a chaperone that shuttles the snoRNPs between the Cajal bodies and nucleoli [18]. The 18S, 5.8S and 28S rRNAs, transcribed by RNA Pol I, and the ribosomal proteins constitute the ribosome. Defects of rRNA transcription and rRNA processing lead to reduced ribosome biogenesis and protein synthesis (Table 2).

Table 1. Summary of the key components of nuclear bodies.

\begin{tabular}{|c|c|c|c|}
\hline $\begin{array}{c}\text { Nuclear Body } \\
\text { Component }\end{array}$ & Synonyms & Notes & $\begin{array}{c}\text { Nuclear Body Component } \\
\text { Localization References }\end{array}$ \\
\hline \multicolumn{4}{|l|}{ Nucleolus } \\
\hline \multicolumn{4}{|l|}{ Proteins } \\
\hline Nucleophosmin & $\mathrm{B} 23$ & Multifunctional chaperone & [19] \\
\hline Nucleolin & $\mathrm{C} 23$ & $\begin{array}{l}\text { pre-rRNA processing } \\
\text { RNA polymerase I transcription }\end{array}$ & [19] \\
\hline Fibrillarin & & $\begin{array}{l}\text { Box C/D snoRNP component } \\
\text { pre-rRNA 2'-O-methyltransferase }\end{array}$ & {$[20]$} \\
\hline NHP2L1 & $\begin{array}{l}15.5 \mathrm{~K} \\
\text { NHPX }\end{array}$ & $\begin{array}{l}\text { Box C/D snoRNP component } \\
\text { pre-rRNA 2'-O-methylation }\end{array}$ & {$[21]$} \\
\hline NOP56 & & $\begin{array}{l}\text { Box C/D snoRNP component } \\
\text { pre-rRNA 2'-O-methylation }\end{array}$ & {$[22]$} \\
\hline NOP58 & & $\begin{array}{l}\text { Box C/D snoRNP component } \\
\text { pre-rRNA 2'-O-methylation }\end{array}$ & [22] \\
\hline Dyskerin & $\begin{array}{l}\text { DKC1 } \\
\text { NAP57 } \\
\text { NOLA4 } \\
\end{array}$ & $\begin{array}{l}\text { H/ACA snoRNP component } \\
\text { pre-rRNA pseudouridylase } \\
\text { Telomerase component }\end{array}$ & [23] \\
\hline GAR1 & NOLA1 & $\begin{array}{l}\text { H/ACA snoRNP component } \\
\text { pre-rRNA pseudouridylation } \\
\text { Telomerase component }\end{array}$ & [24] \\
\hline NHP2 & NOLA2 & $\begin{array}{l}\text { H/ACA snoRNP component } \\
\text { pre-rRNA pseudouridylation } \\
\text { Telomerase component }\end{array}$ & [25] \\
\hline NOP10 & NOLA3 & $\begin{array}{l}\text { H/ACA snoRNP component } \\
\text { pre-rRNA pseudouridylation } \\
\text { Telomerase component }\end{array}$ & [25] \\
\hline NOPP140 & NOLC1 & $\begin{array}{l}\text { Box C/D snoRNP chaperone } \\
\text { Transcription }\end{array}$ & [26] \\
\hline RNA polymerase I & & Transcription & {$[12,13,27]$} \\
\hline $\begin{array}{l}40 \text { S ribosomal } \\
\text { subunit }\end{array}$ & & $\begin{array}{l}\text { 40S small ribosomal subunit } \\
\text { Translation }\end{array}$ & {$[12,13]$} \\
\hline $\begin{array}{l}60 \mathrm{~S} \text { ribosomal } \\
\text { subunit }\end{array}$ & & $\begin{array}{l}\text { 60S large ribosomal subunit } \\
\text { Translation }\end{array}$ & {$[12,13]$} \\
\hline
\end{tabular}


Table 1. Cont.

\begin{tabular}{|c|c|c|c|}
\hline $\begin{array}{l}\text { Nuclear Body } \\
\text { Component }\end{array}$ & Synonyms & Notes & $\begin{array}{l}\text { Nuclear Body Component } \\
\text { Localization References }\end{array}$ \\
\hline \multicolumn{4}{|l|}{ Nucleolus } \\
\hline \multicolumn{4}{|l|}{ RNAs } \\
\hline U3 snoRNA & & $\begin{array}{l}\text { Box C/D snoRNA } \\
\text { pre-rRNA processing }\end{array}$ & [28] \\
\hline U8 snoRNA & & $\begin{array}{l}\text { Box C/D snoRNA } \\
\text { pre-rRNA processing }\end{array}$ & {$[28,29]$} \\
\hline U13 snoRNA & & $\begin{array}{l}\text { Box C/D snoRNA } \\
\text { pre-rRNA processing }\end{array}$ & [28] \\
\hline U14 snoRNA & & $\begin{array}{l}\text { Box C/D snoRNA } \\
\text { pre-rRNA processing }\end{array}$ & [29] \\
\hline U17 snoRNA & E1 snoRNA & $\begin{array}{l}\text { Box } \mathrm{H} / \mathrm{ACA} \text { snoRNA } \\
\text { pre-rRNA processing }\end{array}$ & [30] \\
\hline E2 snoRNA & & $\begin{array}{l}\text { Box H/ACA snoRNA } \\
\text { pre-rRNA processing }\end{array}$ & [30] \\
\hline E3 snoRNA & & $\begin{array}{l}\text { Box H/ACA snoRNA } \\
\text { pre-rRNA processing }\end{array}$ & [30] \\
\hline \multicolumn{4}{|l|}{ Nuclear Speckle } \\
\hline \multicolumn{4}{|l|}{ Proteins } \\
\hline SRSF1 & $\begin{array}{l}\text { SF2 } \\
\text { ASF } \\
\text { SRp30a }\end{array}$ & $\begin{array}{l}\text { SRSF family } \\
\text { Constitutive and alternative splicing }\end{array}$ & [31] \\
\hline SRSF2 & $\begin{array}{l}\mathrm{SC} 35 \\
\mathrm{SRp} 30 \mathrm{~b}\end{array}$ & $\begin{array}{l}\text { SRSF family } \\
\text { Constitutive and alternative splicing }\end{array}$ & [32] \\
\hline SRSF3 & SRp20 & $\begin{array}{l}\text { SRSF family } \\
\text { Constitutive and alternative splicing }\end{array}$ & [31] \\
\hline SRSF4 & SRp75 & $\begin{array}{l}\text { SRSF family } \\
\text { Constitutive and alternative splicing }\end{array}$ & {$[33,34]$} \\
\hline SRSF5 & SRp40 & $\begin{array}{l}\text { SRSF family } \\
\text { Constitutive and alternative splicing }\end{array}$ & [34] \\
\hline SRSF6 & SRp55 & $\begin{array}{l}\text { SRSF family } \\
\text { Constitutive and alternative splicing }\end{array}$ & {$[33,34]$} \\
\hline SRSF7 & 9G8 & $\begin{array}{l}\text { SRSF family } \\
\text { Constitutive and alternative splicing }\end{array}$ & [34] \\
\hline CLK & STY & $\begin{array}{l}\text { Dual specificity protein kinase } \\
\text { SRSF phosphorylation }\end{array}$ & [35] \\
\hline PRP3 & & $\begin{array}{l}\text { U4/U6 snRNP component } \\
\text { pre-mRNA splicing }\end{array}$ & [34] \\
\hline PRP6 & & $\begin{array}{l}\text { U4/U6-U5 tri-snRNP component } \\
\text { pre-mRNA splicing }\end{array}$ & [34] \\
\hline PRP8 & & $\begin{array}{l}\text { U5 snRNP component } \\
\text { pre-mRNA splicing }\end{array}$ & [34] \\
\hline $\begin{array}{l}\mathrm{U} 5 \mathrm{snRNP} 200 \mathrm{kDa} \\
\text { protein }\end{array}$ & BRR2 & $\begin{array}{l}\text { U5 snRNP component } \\
\text { pre-mRNA splicing }\end{array}$ & [34] \\
\hline
\end{tabular}


Table 1. Cont.

\begin{tabular}{|c|c|c|c|}
\hline $\begin{array}{c}\text { Nuclear Body } \\
\text { Component }\end{array}$ & Synonyms & Notes & $\begin{array}{l}\text { Nuclear Body Component } \\
\text { Localization References }\end{array}$ \\
\hline \multicolumn{4}{|l|}{ Nuclear Speckle } \\
\hline \multicolumn{4}{|l|}{ Proteins } \\
\hline $\begin{array}{l}\text { U5 snRNP } 116 \mathrm{kDa} \\
\text { protein }\end{array}$ & SNU114 & $\begin{array}{l}\text { U5 snRNP component } \\
\text { pre-mRNA splicing }\end{array}$ & {$[33,34]$} \\
\hline CPSF 160 & CPSF1 & $\begin{array}{l}\text { CPSF complex } \\
\text { pre-mRNA 3' end processing }\end{array}$ & [34] \\
\hline CPSF 100 & CPSF2 & $\begin{array}{l}\text { CPSF complex } \\
\text { pre-mRNA 3' end processing }\end{array}$ & [34] \\
\hline CPSF73 & CPSF3 & $\begin{array}{l}\text { CPSF complex } \\
\text { pre-mRNA 3' end processing }\end{array}$ & [34] \\
\hline CPSF30 & CPSF4 & $\begin{array}{l}\text { CPSF complex } \\
\text { pre-mRNA 3' end processing }\end{array}$ & [34] \\
\hline CFIm68 & CPSF6 & $\begin{array}{l}\mathrm{CFI}_{\mathrm{m}} \text { complex } \\
\text { pre-mRNA 3' end processing }\end{array}$ & [34] \\
\hline CSTF64 & CSTF2 & $\begin{array}{l}\text { CSTF complex } \\
\text { pre-mRNA 3' end processing }\end{array}$ & [34] \\
\hline RNA polymerase II & & Transcription & {$[34,36]$} \\
\hline SON & & pre-mRNA splicing & [34] \\
\hline MAGOH & & $\begin{array}{l}\text { Exon junction complex } \\
\text { mRNA export and NMD }\end{array}$ & [34] \\
\hline eIF4AIII & DDX48 & $\begin{array}{l}\text { Exon junction complex } \\
\text { mRNA export and NMD }\end{array}$ & [34] \\
\hline RNPS1 & & $\begin{array}{l}\text { Exon junction complex } \\
\text { mRNA export and NMD }\end{array}$ & {$[33,34]$} \\
\hline Y14 & RBM8A & $\begin{array}{l}\text { Exon junction complex } \\
\text { mRNA export and NMD }\end{array}$ & [34] \\
\hline Aly/REF & & $\begin{array}{l}\text { Exon junction complex } \\
\text { mRNA export and NMD }\end{array}$ & [34] \\
\hline RAE1 & & mRNA export & [34] \\
\hline \multicolumn{4}{|l|}{ RNAs } \\
\hline U1 snRNA & & $\begin{array}{l}\text { U1 snRNP component } \\
\text { pre-mRNA splicing }\end{array}$ & [37] \\
\hline U2 snRNA & & $\begin{array}{l}\text { U2 snRNP component } \\
\text { pre-mRNA splicing }\end{array}$ & [37] \\
\hline$M A L A T 1$ RNA & NEAT2 & Long ncRNA & [38] \\
\hline Poly(A)+ RNA & & RNA with a poly(A) tail & [39] \\
\hline
\end{tabular}


Table 1. Cont.

\begin{tabular}{|c|c|c|c|}
\hline $\begin{array}{l}\text { Nuclear Body } \\
\text { Component }\end{array}$ & Synonyms & Notes & $\begin{array}{l}\text { Nuclear Body Component } \\
\text { Localization References }\end{array}$ \\
\hline \multicolumn{4}{|l|}{ Nuclear Stress Body } \\
\hline \multicolumn{4}{|l|}{ Proteins } \\
\hline HSF1 & & $\begin{array}{l}\text { Heat shock transcription factor family } \\
\text { Transcription }\end{array}$ & [40] \\
\hline HSF2 & & $\begin{array}{l}\text { Heat shock transcription factor family } \\
\text { Transcription }\end{array}$ & [41] \\
\hline SAF-B & $\begin{array}{l}\text { HAP } \\
\text { HET }\end{array}$ & $\begin{array}{l}\text { S/MAR binding protein } \\
\text { Transcription }\end{array}$ & {$[42]$} \\
\hline Sam68 & KHDRBS1 & $\begin{array}{l}\text { Transcription } \\
\text { Alternative splicing }\end{array}$ & [43] \\
\hline SRSF1 & $\begin{array}{l}\text { ASF } \\
\text { SF2 }\end{array}$ & $\begin{array}{l}\text { SRSF family } \\
\text { Constitutive and alternative splicing }\end{array}$ & [43] \\
\hline SRSF7 & 9G8 & $\begin{array}{l}\text { SRSF family } \\
\text { Constitutive and alternative splicing }\end{array}$ & [43] \\
\hline SRSF9 & SRp30c & $\begin{array}{l}\text { SRSF family } \\
\text { Constitutive and alternative splicing }\end{array}$ & [43] \\
\hline RNA polymerase II & & Transcription & [44] \\
\hline \multicolumn{4}{|l|}{ RNA } \\
\hline Satellite III ncRNA & & $\begin{array}{l}\text { Long ncRNA transcribed from the } \\
\text { pericentric heterochromatic } 9 p 12 \text { locus }\end{array}$ & [44] \\
\hline \multicolumn{4}{|l|}{ Transcription Factory } \\
\hline \multicolumn{4}{|l|}{ Proteins } \\
\hline RNA polymerase I & & Transcription & {$[45,46]$} \\
\hline RNA polymerase II & & Transcription & {$[45,46]$} \\
\hline RNA polymerase III & & Transcription & {$[45,46]$} \\
\hline \multicolumn{4}{|l|}{ Cajal Body } \\
\hline \multicolumn{4}{|l|}{ Proteins } \\
\hline Coilin & & Function unknown & {$[47,48]$} \\
\hline Fibrillarin & & $\begin{array}{l}\text { Box C/D snoRNP component } \\
\text { pre-rRNA 2'-O-methyltransferase }\end{array}$ & [49] \\
\hline NHP2L1 & $\begin{array}{l}15.5 \mathrm{~K} \\
\mathrm{NHPX}\end{array}$ & $\begin{array}{l}\text { Box C/D snoRNP component } \\
\text { pre-rRNA 2'-O-methylation }\end{array}$ & {$[21,50]$} \\
\hline NOP56 & & $\begin{array}{l}\text { Box C/D snoRNP component } \\
\text { pre-rRNA 2'-O-methylation }\end{array}$ & {$[50]$} \\
\hline NOP58 & & $\begin{array}{l}\text { Box C/D snoRNP component } \\
\text { pre-rRNA 2'-O-methylation }\end{array}$ & {$[50]$} \\
\hline Dyskerin & $\begin{array}{l}\text { DKC1 } \\
\text { NAP57 } \\
\text { NOLA4 } \\
\end{array}$ & $\begin{array}{l}\text { H/ACA snoRNP component } \\
\text { pre-rRNA pseudouridylase } \\
\text { Telomerase component }\end{array}$ & {$[51]$} \\
\hline GAR1 & NOLA1 & $\begin{array}{l}\text { H/ACA snoRNP component } \\
\text { pre-rRNA pseudouridylation } \\
\text { Telomerase component }\end{array}$ & {$[52]$} \\
\hline
\end{tabular}


Table 1. Cont.

\begin{tabular}{|c|c|c|c|}
\hline $\begin{array}{l}\text { Nuclear Body } \\
\text { Component }\end{array}$ & Synonyms & Notes & $\begin{array}{l}\text { Nuclear Body Component } \\
\text { Localization References }\end{array}$ \\
\hline \multicolumn{4}{|l|}{ Cajal Body } \\
\hline \multicolumn{4}{|l|}{ Proteins } \\
\hline NHP2 & NOLA2 & $\begin{array}{l}\text { H/ACA snoRNP component } \\
\text { pre-rRNA pseudouridylation } \\
\text { Telomerase component }\end{array}$ & {$[52]$} \\
\hline NOP10 & NOLA3 & $\begin{array}{l}\text { H/ACA snoRNP component } \\
\text { pre-rRNA pseudouridylation } \\
\text { Telomerase component }\end{array}$ & [52] \\
\hline TERT & & $\begin{array}{l}\text { Telomerase component } \\
\text { Reverse transcriptase }\end{array}$ & [53] \\
\hline TCAB1 & WRAP53 & Telomerase component & [54] \\
\hline NOPP140 & NOLC1 & $\begin{array}{l}\text { Box C/D snoRNP chaperone } \\
\text { Transcription }\end{array}$ & [18] \\
\hline SMN1 & GEMIN1 & $\begin{array}{l}\text { SMN complex } \\
\text { Spliceosomal snRNP biogenesis }\end{array}$ & [55] \\
\hline \multicolumn{4}{|l|}{ RNAs } \\
\hline U85 scaRNA & & $\begin{array}{l}\text { scaRNA } \\
\text { snRNA modification }\end{array}$ & [56] \\
\hline U87 scaRNA & & $\begin{array}{l}\text { scaRNA } \\
\text { snRNA modification }\end{array}$ & [56] \\
\hline U88 scaRNA & & $\begin{array}{l}\text { scaRNA } \\
\text { snRNA modification }\end{array}$ & [56] \\
\hline U89 scaRNA & & $\begin{array}{l}\text { scaRNA } \\
\text { snRNA modification }\end{array}$ & [56] \\
\hline U90 scaRNA & & $\begin{array}{l}\text { scaRNA } \\
\text { snRNA modification }\end{array}$ & [56] \\
\hline U91 scaRNA & & $\begin{array}{l}\text { scaRNA } \\
\text { snRNA modification }\end{array}$ & [56] \\
\hline U92 scaRNA & & $\begin{array}{l}\text { scaRNA } \\
\text { snRNA modification }\end{array}$ & [56] \\
\hline$U 2$ snRNA & & $\begin{array}{l}\text { U2 snRNP component } \\
\text { pre-mRNA splicing }\end{array}$ & {$[57,58]$} \\
\hline U4 snRNA & & $\begin{array}{l}\text { U4 snRNP component } \\
\text { pre-mRNA splicing }\end{array}$ & {$[57,58]$} \\
\hline U5 snRNA & & $\begin{array}{l}\text { U5 snRNP component } \\
\text { pre-mRNA splicing }\end{array}$ & {$[57,58]$} \\
\hline U6 snRNA & & $\begin{array}{l}\text { U6 snRNP component } \\
\text { pre-mRNA splicing }\end{array}$ & {$[57,58]$} \\
\hline U3 snoRNA & & $\begin{array}{l}\text { Box C/D snoRNA } \\
\text { pre-rRNA processing }\end{array}$ & [59] \\
\hline U8 snoRNA & & $\begin{array}{l}\text { Box C/D snoRNA } \\
\text { pre-rRNA processing }\end{array}$ & [59] \\
\hline U14 snoRNA & & $\begin{array}{l}\text { Box C/D snoRNA } \\
\text { pre-rRNA processing }\end{array}$ & [59] \\
\hline TERC RNA & TR & Telomerase complex & [5] \\
\hline
\end{tabular}


Table 1. Cont.

\begin{tabular}{|c|c|c|c|}
\hline $\begin{array}{c}\text { Nuclear Body } \\
\text { Component }\end{array}$ & Synonyms & Notes & $\begin{array}{r}\text { Nuclear Body Component } \\
\text { Localization References }\end{array}$ \\
\hline \multicolumn{4}{|c|}{ Gemini of Cajal Body } \\
\hline \multicolumn{4}{|l|}{ Proteins } \\
\hline SMN1 & GEMIN1 & $\begin{array}{l}\text { SMN complex } \\
\text { Spliceosomal snRNP biogenesis }\end{array}$ & {$[60]$} \\
\hline GEMIN2 & SIP1 & $\begin{array}{l}\text { SMN complex } \\
\text { Spliceosomal snRNP biogenesis }\end{array}$ & {$[61]$} \\
\hline GEMIN3 & & $\begin{array}{l}\text { SMN complex } \\
\text { Spliceosomal snRNP biogenesis }\end{array}$ & {$[62]$} \\
\hline GEMIN4 & & $\begin{array}{l}\text { SMN complex } \\
\text { Spliceosomal snRNP biogenesis }\end{array}$ & [63] \\
\hline GEMIN5 & & $\begin{array}{l}\text { SMN complex } \\
\text { Spliceosomal snRNP biogenesis }\end{array}$ & [64] \\
\hline GEMIN6 & SIP2 & $\begin{array}{l}\text { SMN complex } \\
\text { Spliceosomal snRNP biogenesis }\end{array}$ & [65] \\
\hline GEMIN7 & SIP3 & $\begin{array}{l}\text { SMN complex } \\
\text { Spliceosomal snRNP biogenesis }\end{array}$ & [66] \\
\hline GEMIN8 & & $\begin{array}{l}\text { SMN complex } \\
\text { Spliceosomal snRNP biogenesis }\end{array}$ & [67] \\
\hline ZPR1 & & $\begin{array}{l}\text { SMN complex } \\
\text { SMN localization }\end{array}$ & {$[68]$} \\
\hline \multicolumn{4}{|l|}{ Histone Locus Body } \\
\hline \multicolumn{4}{|l|}{ Proteins } \\
\hline NPAT & $\mathrm{p} 220$ & Histone gene transcription & [69] \\
\hline SLBP & HBP & Histone pre-mRNA 3' end processing & [70] \\
\hline LSm10 & & $\begin{array}{l}\text { U7 snRNP component } \\
\text { Histone pre-mRNA } 3 \text { ' end processing }\end{array}$ & {$[70]$} \\
\hline LSm11 & & $\begin{array}{l}\text { U7 snRNP component } \\
\text { Histone pre-mRNA } 3 \text { ' end processing }\end{array}$ & {$[70,71]$} \\
\hline FLASH & CASP8AP2 & Histone gene transcription & [72] \\
\hline NELF A & WHSC2 & $\begin{array}{l}\text { NELF complex } \\
\text { Histone pre-mRNA } 3^{\prime} \text { end processing }\end{array}$ & [73] \\
\hline NELF B & COBRA1 & $\begin{array}{l}\text { NELF complex } \\
\text { Histone pre-mRNA 3' end processing }\end{array}$ & [73] \\
\hline NELF C/D & TH1L & $\begin{array}{l}\text { NELF complex } \\
\text { Histone pre-mRNA 3' end processing }\end{array}$ & [73] \\
\hline NELF E & $\mathrm{RDBP}$ & $\begin{array}{l}\text { NELF complex } \\
\text { Histone pre-mRNA 3' end processing }\end{array}$ & [73] \\
\hline HiNF-P & & Transcription & [74] \\
\hline ZPR1 & & NPAT, SMN, coilin localization to HLBs & [75] \\
\hline Coilin & & Function unknown & [76] \\
\hline \multicolumn{4}{|l|}{ RNA } \\
\hline U7 snRNA & & $\begin{array}{l}\text { U7 snRNP component } \\
\text { Histone pre-mRNA 3' end processing }\end{array}$ & [71] \\
\hline \multicolumn{4}{|l|}{ DNA } \\
\hline Histone loci & & Replication-dependent histone genes & {$[71,77]$} \\
\hline
\end{tabular}


Table 1. Cont.

\begin{tabular}{|c|c|c|c|}
\hline $\begin{array}{l}\text { Nuclear Body } \\
\text { Component }\end{array}$ & Synonyms & Notes & $\begin{array}{l}\text { Nuclear Body Component } \\
\text { Localization References }\end{array}$ \\
\hline \multicolumn{4}{|l|}{ Paraspeckle } \\
\hline \multicolumn{4}{|l|}{ Proteins } \\
\hline NONO & $\mathrm{p} 54 \mathrm{nrb}$ & DBHS family & [78] \\
\hline PSP1 & PSPC1 & DBHS family & [78] \\
\hline PSP2 & $\begin{array}{l}\text { CoAA } \\
\text { RBM14 }\end{array}$ & $\begin{array}{l}\text { Transcription } \\
\text { Splicing }\end{array}$ & [78] \\
\hline SFPQ & PSF & DBHS family & [79] \\
\hline CFIm68 & CPSF6 & $\begin{array}{l}\mathrm{CFI}_{\mathrm{m}} \text { complex } \\
\text { pre-mRNA 3' end processing }\end{array}$ & [80] \\
\hline \multicolumn{4}{|l|}{ RNAs } \\
\hline NEAT1 RNA & $\begin{array}{l}M E N \varepsilon / \beta \\
\operatorname{VINC}\end{array}$ & Mammal-specific long ncRNA & [81-83] \\
\hline Ctn RNA & & $\begin{array}{l}\text { Mouse-specific isoform transcribed from the } \\
\text { Slc7a2 locus }\end{array}$ & [79] \\
\hline
\end{tabular}

Abbreviations: $\mathrm{CFI}_{\mathrm{m}}$, mammalian cleavage factor I; CPSF, cleavage and polyadenylation specificity factor; CSTF, cleavage stimulation factor; DBHS, Drosophila behavior/human splicing; HLB, histone locus body; mRNA, messenger RNA; ncRNA, non-coding RNA; NELF, negative elongation factor; NMD, nonsense-mediated mRNA decay; NPAT, nuclear protein ataxia telangiectasia locus; pre-mRNA, precursor messenger RNA; pre-rRNA, precursor ribosomal RNA; scaRNA, small Cajal body-specific RNA; S/MAR, scaffold/matrix attachment region; SMN, survival of motor neuron; snoRNA, small nucleolar RNA; snoRNP, small nucleolar ribonucleoprotein; snRNA, small nuclear RNA; snRNP, small nuclear ribonucleoprotein; SRSF, serine/arginine-rich splicing factor.

Table 2. Selected examples of model systems deficient for nuclear body components.

\begin{tabular}{|c|c|c|c|c|}
\hline $\begin{array}{c}\text { Nuclear Body } \\
\text { Component }\end{array}$ & $\begin{array}{l}\text { Model } \\
\text { System }\end{array}$ & $\begin{array}{l}\text { Experimental } \\
\text { Manipulation }\end{array}$ & Phenotype & References \\
\hline \multicolumn{5}{|l|}{ Nucleolus } \\
\hline \multicolumn{5}{|l|}{ Proteins } \\
\hline$?$ & $\begin{array}{l}\text { African clawed } \\
\text { frog }\end{array}$ & Anucleolate mutant & $\begin{array}{l}\text { Absence of rRNA synthesis } \\
\text { Developmental arrest }\end{array}$ & [8] \\
\hline Nucleophosmin & HeLa cells & $\begin{array}{c}\text { Transduction of NPM } \\
\text { shuttling defective } \\
\text { mutants }\end{array}$ & $\begin{array}{l}\text { Nuclear export of } 40 \mathrm{~S} \text { and } 60 \mathrm{~S} \\
\text { ribosomal subunits } \\
\text { Protein synthesis }\end{array}$ & [14] \\
\hline Nucleolin & HeLa cells & siRNA KD of $N C L$ & RNA Pol I transcription & [16] \\
\hline Fibrillarin & Budding yeast & $\begin{array}{l}\text { Conditionally lethal } \\
\text { allele of NOP1 }\end{array}$ & $\begin{array}{l}18 \mathrm{~S} \text { rRNA } \\
\text { Ribosome biogenesis } \\
\text { Growth rate }\end{array}$ & [84] \\
\hline Dyskerin & HeLa cells & siRNA KD of $D K C l$ & $\begin{array}{l}\text { Pseudouridylation of rRNAs } \\
\text { Ribosome affinity for substrate } \\
\text { Translational fidelity }\end{array}$ & [85] \\
\hline Dyskerin & $\begin{array}{c}\text { Cultured mouse } \\
\text { embryonic } \\
\text { fibroblasts } \\
\end{array}$ & $\begin{array}{l}\text { Hypomorphic allele } \\
\text { of } D k c 1\end{array}$ & $\begin{array}{l}\text { Pseudouridylation of rRNAs } \\
\text { Ribosome affinity for substrate } \\
\text { Translational fidelity }\end{array}$ & [85] \\
\hline
\end{tabular}


Table 2. Cont.

\begin{tabular}{|c|c|c|c|c|}
\hline $\begin{array}{c}\text { Nuclear Body } \\
\text { Component }\end{array}$ & $\begin{array}{l}\text { Model } \\
\text { System }\end{array}$ & $\begin{array}{l}\text { Experimental } \\
\text { Manipulation }\end{array}$ & Phenotype & References \\
\hline \multicolumn{5}{|l|}{ Nucleolus } \\
\hline \multicolumn{5}{|l|}{ Proteins } \\
\hline Dyskerin & Budding yeast & $\begin{array}{l}\text { Hypomorphic allele } \\
\text { of } C B F 5\end{array}$ & $\begin{array}{l}\text { Pseudouridylation of rRNAs } \\
\text { Ribosome affinity for substrate } \\
\text { Translational fidelity }\end{array}$ & [85] \\
\hline RNA Pol I & $\begin{array}{l}\text { Human peripheral } \\
\text { blood lymphoblasts } \\
\text { and cultured } \\
\text { fibroblasts } \\
\end{array}$ & $\begin{array}{l}\text { Actinomycin D } \\
\text { treatment }\end{array}$ & $\begin{array}{l}\text { Condensation of nucleolar } \\
\text { chromatin } \\
\text { Coilin enriched in nucleolar caps }\end{array}$ & [86] \\
\hline RPS19 & $\begin{array}{l}\text { DBA patient- } \\
\text { derived CD34- } \\
\text { cells from bone } \\
\text { marrow }\end{array}$ & None & $\begin{array}{l}\text { Mature } 40 \mathrm{~S} \text { ribosomal subunit } \\
\text { pre-rRNA processing defect }\end{array}$ & [87] \\
\hline RPS19 & $\begin{array}{c}\text { Human } \\
\text { erythroleukemia } \\
\text { cells } \\
\end{array}$ & siRNA KD of RPS19 & pre-rRNA processing defect & [87] \\
\hline \multicolumn{5}{|l|}{ RNA } \\
\hline U3 snoRNA & Budding yeast & $\begin{array}{c}\text { Conditionally } \\
\text { repressible } S N R 17 A \\
\text { gene } \\
\end{array}$ & $\begin{array}{l}\text { 18S rRNA } \\
\text { Growth rate }\end{array}$ & {$[88]$} \\
\hline \multicolumn{5}{|c|}{ Nuclear Speckle } \\
\hline \multicolumn{5}{|l|}{ Proteins } \\
\hline SRSF1 & HeLa cells & siRNA KD of $S R S F 1$ & $\begin{array}{l}\text { Nuclear speckle localization of } \\
\text { pre-mRNA processing factors } \\
\text { Enlarged nuclear speckles }\end{array}$ & [89] \\
\hline SRSF1 & $\begin{array}{c}\text { Human } \\
\text { osteosarcoma cells }\end{array}$ & siRNA KD of $S R S F 1$ & Transcription & [89] \\
\hline SRSF2 & $\begin{array}{c}\text { Human } \\
\text { osteosarcoma cells }\end{array}$ & siRNA KD of $S R S F 2$ & Transcription & [89] \\
\hline CLK & $\begin{array}{l}\text { Human epidermoid } \\
\text { carcinoma cells }\end{array}$ & $\begin{array}{c}\text { Overexpression of } \\
\text { murine CLK } \\
\end{array}$ & $\begin{array}{l}\text { pre-mRNA splicing } \\
\text { Disrupted nuclear speckles }\end{array}$ & [90] \\
\hline CLK & $\begin{array}{l}\text { Human epidermoid } \\
\text { carcinoma cells }\end{array}$ & $\begin{array}{c}\text { Overexpression of } \\
\text { catalytically inactive } \\
\text { murine CLK } \\
\end{array}$ & $\begin{array}{l}\text { Retention of hypophosphorylated } \\
\text { SRSF proteins in nuclear speckles }\end{array}$ & [90] \\
\hline PRPF6 & HeLa cells & siRNA KD of $P R P F 6$ & $\begin{array}{l}\text { MALATI RNA } \\
\text { Localization of MALAT1 to } \\
\text { nuclear speckles } \\
\text { Nuclear speckles not disrupted }\end{array}$ & [91] \\
\hline SON & HeLa cells & siRNA KD of $S O N$ & $\begin{array}{l}\text { Localization of MALAT1 to } \\
\text { nuclear speckles }\end{array}$ & [91] \\
\hline
\end{tabular}


Table 2. Cont.

\begin{tabular}{|c|c|c|c|c|}
\hline $\begin{array}{l}\text { Nuclear Body } \\
\text { Component }\end{array}$ & $\begin{array}{l}\text { Model } \\
\text { System }\end{array}$ & $\begin{array}{l}\text { Experimental } \\
\text { Manipulation }\end{array}$ & Phenotype & References \\
\hline \multicolumn{5}{|l|}{ Nuclear Speckle } \\
\hline \multicolumn{5}{|l|}{ Proteins } \\
\hline SON & HeLa cells & siRNA KD of $S O N$ & $\begin{array}{l}\text { Localization of pre-mRNA } \\
\text { processing factors to nuclear } \\
\text { speckles } \\
\text { Localization of core EJC proteins } \\
\text { to nuclear speckles } \\
\text { Cell cycle arrest }\end{array}$ & [92] \\
\hline Aly/REF & HeLa cells & $\begin{array}{l}\text { siRNA KD of } \\
\text { ALYREF }\end{array}$ & mRNA export & [93] \\
\hline Aly/REF & HeLa cells & $\begin{array}{c}\text { siRNA KD of } \\
\text { ALYREF }\end{array}$ & $\begin{array}{l}\text { mRNA export } \\
\text { Poly(A)+ RNA in nuclear } \\
\text { speckles }\end{array}$ & [94] \\
\hline \multicolumn{5}{|l|}{ RNAs } \\
\hline$M A L A T 1$ & HeLa cells & ASO KD of MALAT1 & $\begin{array}{l}\text { Nuclear speckle integrity } \\
\text { Aberrant alternative splicing } \\
\text { SRSF1 and SRSF } 2 \\
\text { Altered ratio of dephosphorylated to } \\
\text { phosphorylated SRSF proteins }\end{array}$ & [91] \\
\hline Malat1 & Mouse & $\mathrm{KO}$ & $\begin{array}{l}\text { Localization of nuclear speckle } \\
\text { proteins unaffected } \\
\text { Viable and fertile }\end{array}$ & {$[95,96]$} \\
\hline U1 snRNA & HeLa cells & $\begin{array}{l}\text { ASO KD of } \\
U 1 \text { snRNA }\end{array}$ & $\begin{array}{l}\text { Splicing inhibition } \\
\text { Enlarged speckles } \\
\text { Number of nuclear speckles } \\
\text { Transcription }\end{array}$ & [97] \\
\hline U2 snRNA & HeLa cells & $\begin{array}{l}\text { ASO KD of } \\
U 2 \text { snRNA }\end{array}$ & $\begin{array}{l}\text { Splicing inhibition } \\
\text { Enlarged speckles } \\
\text { Number of nuclear speckles } \\
\text { Transcription }\end{array}$ & [97] \\
\hline \multicolumn{5}{|c|}{ Nuclear Stress Body } \\
\hline \multicolumn{5}{|l|}{ Proteins } \\
\hline HSF1 & $\begin{array}{l}\text { Cultured human } \\
\text { embryonic kidney } \\
\text { cells } \\
\end{array}$ & shRNA KD of $H S F 1$ & Satellite III transcription & [98] \\
\hline HSF1 & HeLa cells & shRNA KD of $H S F 1$ & $\begin{array}{l}\text { HSF2 protein } \\
\text { No nSBs upon heat shock }\end{array}$ & [98] \\
\hline HSF2 & $\begin{array}{l}\text { Cultured human } \\
\text { embryonic kidney } \\
\text { cells }\end{array}$ & siRNA KD of $H S F 2$ & $\begin{array}{l}\text { Satellite III transcription } \\
\text { No effect on HSF1 localization to } \\
\text { nSBs upon heat shock }\end{array}$ & [98] \\
\hline
\end{tabular}


Table 2. Cont.

\begin{tabular}{|c|c|c|c|c|}
\hline $\begin{array}{c}\text { Nuclear Body } \\
\text { Component }\end{array}$ & $\begin{array}{l}\text { Model } \\
\text { System }\end{array}$ & $\begin{array}{l}\text { Experimental } \\
\text { Manipulation }\end{array}$ & Phenotype & References \\
\hline \multicolumn{5}{|c|}{ Transcription Factory } \\
\hline \multicolumn{5}{|l|}{ Proteins } \\
\hline RNA Pol I & Human cells & $\begin{array}{c}\text { Actinomycin D } \\
\text { treatment }\end{array}$ & Coilin enriched in nucleolar caps & [86] \\
\hline RNA Pol II & Human cells & $\begin{array}{c}\alpha \text {-Amanitin or DRB } \\
\text { treatment }\end{array}$ & $\begin{array}{l}\text { Chromatin decondensation } \\
\text { Loss of nucleolar structure }\end{array}$ & {$[86]$} \\
\hline RNA Pol II & HeLa cells & $\alpha$-Amanitin treatment & BrUTP incorporation & {$[99,100]$} \\
\hline RNA Pol II & Canine kidney cells & $\begin{array}{c}\alpha-\text { Amanitin, DRB, } \\
\mathrm{H} 8, \text { or actinomycin D } \\
\text { treatment }\end{array}$ & $\begin{array}{l}\text { Redistribution of RNA Pol II to } \\
\text { enlarged nuclear speckles }\end{array}$ & [36] \\
\hline RNA Pol III & HeLa cells & $\alpha$-Amanitin treatment & BrUTP incorporation & {$[100]$} \\
\hline \multicolumn{5}{|l|}{ Cajal Body } \\
\hline \multicolumn{5}{|l|}{ Proteins } \\
\hline Coilin & Mouse & KO & $\begin{array}{l}\text { Viability } \\
\text { Residual CBs present } \\
\text { No SMN localization to CBs } \\
\text { No Sm protein localization to CBs }\end{array}$ & {$[101,102]$} \\
\hline Coilin & $\begin{array}{l}\text { African clawed } \\
\text { frog oocyte }\end{array}$ & Coilin removal by IP & $\begin{array}{l}\text { CBs present } \\
\text { No Sm protein localization to CBs }\end{array}$ & [103] \\
\hline Coilin & Fruit fly & $\begin{array}{l}\text { Amorphic alleles of } \\
\text { coil }\end{array}$ & $\begin{array}{l}\text { No CBs } \\
\text { No effect on HLBs } \\
\text { Viable and fertile } \\
\end{array}$ & {$[76]$} \\
\hline Coilin & Fruit fly & $\begin{array}{l}\text { Amorphic alleles of } \\
\text { coil }\end{array}$ & $\begin{array}{l}\text { No CBs } \\
\text { No scaRNA localization to CBs } \\
\text { snRNAs properly modified }\end{array}$ & [104] \\
\hline Dyskerin & $\begin{array}{c}\text { DKC } \\
\text { patient-derived } \\
\text { iPSCs } \\
\end{array}$ & None & $\begin{array}{l}\text { Telomerase assembly } \\
\text { Telomere synthesis }\end{array}$ & [105] \\
\hline TERT & $\begin{array}{c}\text { DKC } \\
\text { patient-derived } \\
\text { iPSCs } \\
\end{array}$ & None & $\begin{array}{l}\text { Telomerase levels } \\
\text { Telomere synthesis }\end{array}$ & {$[105]$} \\
\hline TCAB1 & $\begin{array}{l}\text { DKC patient- } \\
\text { derived iPSCs }\end{array}$ & None & $\begin{array}{l}\text { Telomerase activity unaffected } \\
\text { Telomerase localization to CBs } \\
\text { Telomere synthesis }\end{array}$ & [105] \\
\hline TCAB1 & HeLa cells & $\begin{array}{l}\text { shRNA KD of } \\
\text { WRAP53 }\end{array}$ & $\begin{array}{l}\text { TERC localization to CBs } \\
\text { TERC localization to telomeres } \\
\text { Telomere synthesis }\end{array}$ & [54] \\
\hline NOPP140 & $\begin{array}{l}\text { Cultured SMA } \\
\text { patient-derived } \\
\text { fibroblasts }\end{array}$ & None & $\begin{array}{l}\text { Localization of dyskerin and } \\
\text { GAR1 to CBs } \\
\text { Localization of NOPP140 } \\
\text { correlated with disease severity }\end{array}$ & [106] \\
\hline
\end{tabular}


Table 2. Cont.

\begin{tabular}{|c|c|c|c|c|}
\hline $\begin{array}{l}\text { Nuclear Body } \\
\text { Component }\end{array}$ & $\begin{array}{l}\text { Model } \\
\text { System }\end{array}$ & $\begin{array}{l}\text { Experimental } \\
\text { Manipulation }\end{array}$ & Phenotype & References \\
\hline \multicolumn{5}{|l|}{ Cajal Body } \\
\hline \multicolumn{5}{|l|}{ Proteins } \\
\hline SMN1 & $\begin{array}{l}\text { Cultured SMA } \\
\text { patient-derived } \\
\text { lymphoblasts and } \\
\text { fibroblasts }\end{array}$ & None & $\begin{array}{l}\text { Gems } \\
\text { SMN protein }\end{array}$ & {$[107,108]$} \\
\hline SMN1 & HeLa cells & siRNA KD of $S M N 1$ & $\begin{array}{l}\text { Defects in CB formation } \\
\text { snRNPs absent in coilin foci }\end{array}$ & [109] \\
\hline SMN1 & HeLa cells & siRNA KD of $S M N 1$ & $\begin{array}{l}\text { Gem-associated proteins } \\
\text { snRNP assembly } \\
\text { Gems absent }\end{array}$ & {$[110,111]$} \\
\hline SMN1 & Mouse & $\begin{array}{l}\text { Neuron-specific exon } \\
7 \text { deletion of Smn1 }\end{array}$ & $\begin{array}{l}\text { Coilin aggregates } \\
\text { Gems absent } \\
\text { SMA phenotype } \\
\end{array}$ & [112] \\
\hline SMN1 & Mouse & $\begin{array}{l}\text { SMA models varying } \\
\text { in disease severity }\end{array}$ & $\begin{array}{l}\text { SMN complex proteins } \\
\text { snRNP biogenesis } \\
\text { Correlation with disease severity }\end{array}$ & [113] \\
\hline SMN1 & Mouse & $\begin{array}{l}\text { Human SMN2 and } \\
\text { SMN } \Delta 7 \text { expression } \\
\text { in } S m n 1^{-/} \text {background }\end{array}$ & $\begin{array}{l}\text { SMN complex proteins } \\
\text { snRNP biogenesis } \\
\text { Tissue-specific snRNA alterations } \\
\text { Widespread splicing defects } \\
\text { SMA phenotype }\end{array}$ & [114] \\
\hline SMN1 & Fission yeast & $\begin{array}{l}\text { Temperature- } \\
\text { sensitive degron } \\
\text { allele of smn1 } \\
\end{array}$ & $\begin{array}{l}\text { Differential snRNP biogenesis } \\
\text { Splicing defects }\end{array}$ & [115] \\
\hline \multicolumn{5}{|c|}{ Gemini of Cajal Body } \\
\hline \multicolumn{5}{|l|}{ Proteins } \\
\hline SMN1 & $\begin{array}{l}\text { Cultured SMA } \\
\text { patient-derived } \\
\text { lymphoblasts and } \\
\text { fibroblasts } \\
\end{array}$ & None & $\begin{array}{l}\text { Gems } \\
\text { SMN protein }\end{array}$ & {$[107,108]$} \\
\hline SMN1 & HeLa cells & siRNA KD of $S M N 1$ & $\begin{array}{l}\text { Defects in CB formation } \\
\text { snRNPs absent in coilin foci }\end{array}$ & [109] \\
\hline SMN1 & HeLa cells & siRNA KD of $S M N 1$ & $\begin{array}{l}\text { Gem-associated proteins } \\
\text { snRNP assembly } \\
\text { Gems absent }\end{array}$ & {$[110,111]$} \\
\hline SMN1 & Mouse & $\begin{array}{l}\text { Neuron-specific exon } \\
7 \text { deletion of Smn1 }\end{array}$ & $\begin{array}{l}\text { Coilin aggregates } \\
\text { Gems absent } \\
\text { SMA phenotype }\end{array}$ & [112] \\
\hline SMN1 & Mouse & $\begin{array}{l}\text { SMA models varying } \\
\text { in disease severity }\end{array}$ & $\begin{array}{l}\text { SMN complex proteins } \\
\text { snRNP biogenesis } \\
\text { Correlation with disease severity }\end{array}$ & [113] \\
\hline
\end{tabular}


Table 2. Cont.

\begin{tabular}{|c|c|c|c|c|}
\hline $\begin{array}{c}\text { Nuclear Body } \\
\text { Component }\end{array}$ & $\begin{array}{l}\text { Model } \\
\text { System }\end{array}$ & $\begin{array}{l}\text { Experimental } \\
\text { Manipulation }\end{array}$ & Phenotype & References \\
\hline \multicolumn{5}{|c|}{ Gemini of Cajal Body } \\
\hline \multicolumn{5}{|l|}{ Proteins } \\
\hline SMN1 & Mouse & $\begin{array}{l}\text { Human SMN2 and } \\
\text { SMN } \Delta 7 \text { expression } \\
\text { in } S m n 1^{-/} \text {background }\end{array}$ & $\begin{array}{l}\text { SMN complex proteins } \\
\text { snRNP biogenesis } \\
\text { Tissue-specific snRNA alterations } \\
\text { Widespread splicing defects } \\
\text { SMA phenotype }\end{array}$ & [114] \\
\hline SMN1 & Fission yeast & $\begin{array}{c}\text { Temperature- } \\
\text { sensitive degron } \\
\text { allele of smn1 } \\
\end{array}$ & $\begin{array}{l}\text { Differential snRNP biogenesis } \\
\text { Splicing defects }\end{array}$ & {$[115]$} \\
\hline GEMIN2 & HeLa cells & $\begin{array}{l}\text { siRNA KD of } \\
\text { GEMIN2 } \\
\end{array}$ & $\begin{array}{l}\text { GEMIN3 protein } \\
\text { snRNP biogenesis }\end{array}$ & {$[110,111]$} \\
\hline GEMIN3 & HeLa cells & $\begin{array}{c}\text { siRNA KD of } \\
\text { GEMIN3 }\end{array}$ & $\begin{array}{l}\text { GEMIN4 protein } \\
\text { snRNP biogenesis }\end{array}$ & {$[110,111]$} \\
\hline GEMIN3 & Fruit fly & LOF alleles of Gem3 & $\begin{array}{l}\text { SMN protein } \\
\text { Motor defects } \\
\text { Larval lethal } \\
\end{array}$ & {$[116]$} \\
\hline GEMIN4 & HeLa cells & $\begin{array}{l}\text { siRNA KD of } \\
\text { GEMIN4 } \\
\end{array}$ & $\begin{array}{l}\text { GEMIN3 protein } \\
\text { snRNP biogenesis }\end{array}$ & {$[110,111]$} \\
\hline GEMIN5 & HeLa cells & $\begin{array}{l}\text { siRNA KD of } \\
\text { GEMIN5 } \\
\end{array}$ & $\begin{array}{l}\text { No effect on gems } \\
\text { No effect on snRNP biogenesis }\end{array}$ & {$[110,111]$} \\
\hline GEMIN6 & HeLa cells & $\begin{array}{l}\text { siRNA KD of } \\
\text { GEMIN6 } \\
\end{array}$ & $\begin{array}{l}\text { No effect on gems } \\
\text { snRNP biogenesis }\end{array}$ & {$[110,111]$} \\
\hline GEMIN7 & HeLa cells & $\begin{array}{l}\text { siRNA KD of } \\
\text { GEMIN7 }\end{array}$ & snRNP biogenesis & {$[111]$} \\
\hline ZPR1 & HeLa cells & ASO KD of $Z P R 1$ & $\begin{array}{l}\text { SMN localization to gems and } \\
\text { CBs }\end{array}$ & {$[68]$} \\
\hline ZPR1 & Mouse & KO & $\begin{array}{l}\text { Localization of SMN and coilin } \\
\text { to gems and CBs } \\
\text { Mislocalization of snRNPs } \\
\text { Embryonic lethal }\end{array}$ & [117] \\
\hline ZPR1 & Mouse & Heterozygous KO & $\begin{array}{l}\text { Mislocalization of SMN } \\
\text { Motor neuron degeneration } \\
\text { Motor defects }\end{array}$ & [118] \\
\hline ZPR1 & $\begin{array}{l}\text { Cultured mouse } \\
\text { motor neuron-like } \\
\text { cells }\end{array}$ & siRNA KD of Zprl & $\begin{array}{l}\text { Localization of SMN to gems } \\
\text { and CBs } \\
\text { Mislocalization of snRNPs } \\
\text { Axonal defects }\end{array}$ & [117] \\
\hline
\end{tabular}


Table 2. Cont.

\begin{tabular}{|c|c|c|c|c|}
\hline $\begin{array}{l}\text { Nuclear Body } \\
\text { Component }\end{array}$ & $\begin{array}{l}\text { Model } \\
\text { System }\end{array}$ & $\begin{array}{l}\text { Experimental } \\
\text { Manipulation }\end{array}$ & Phenotype & References \\
\hline \multicolumn{5}{|c|}{ Histone Locus Body } \\
\hline \multicolumn{5}{|l|}{ Proteins } \\
\hline NPAT & Mouse & $\begin{array}{l}\text { Retroviral insertion } \\
\text { of Npat }\end{array}$ & Embryonic lethal & [119] \\
\hline SLBP & $\begin{array}{c}\text { Human } \\
\text { osteosarcoma cells }\end{array}$ & siRNA KD of $S L B P$ & $\begin{array}{l}\text { Aberrant histone RNA processing } \\
\text { S phase block } \\
\text { Cell proliferation } \\
\text { Histone mRNA and protein }\end{array}$ & [120] \\
\hline SLBP & HeLa cells & shRNA KD of $S L B P$ & Aberrant histone RNA processing & [73] \\
\hline SLBP & Fruit fly & LOF alleles of $S l b p$ & $\begin{array}{l}\text { Aberrant histone pre-mRNA } \\
\text { processing } \\
\text { Female sterile } \\
\text { Lethal }\end{array}$ & [121] \\
\hline SLBP & Fruit fly & LOF allele of Slbp & No effect on HLBs & [122] \\
\hline LSm10 & Fruit fly & LOF alleles of $\operatorname{Lsm} 10$ & $\begin{array}{l}\text { Aberrant histone pre-mRNA } \\
\text { processing } \\
\text { No U7 snRNA localization to HLBs } \\
\text { Lethal }\end{array}$ & [123] \\
\hline LSm11 & Fruit fly & LOF alleles of $L s m 11$ & $\begin{array}{l}\text { Lsm } 10 \text { protein } \\
\text { Aberrant histone pre-mRNA } \\
\text { processing } \\
\text { No } U 7 \text { snRNA localization to HLBs } \\
\text { Lethal }\end{array}$ & [123] \\
\hline FLASH & HeLa cells & $\begin{array}{c}\text { shRNA KD of } \\
C A S P 8 A P 2\end{array}$ & $\begin{array}{l}\text { Histone mRNA } \\
\text { Histone protein } \\
\text { S phase block }\end{array}$ & [124] \\
\hline FLASH & $\begin{array}{l}\text { Human breast } \\
\text { cancer cells }\end{array}$ & $\begin{array}{l}\text { shRNA KD of } \\
C A S P 8 A P 2\end{array}$ & No HLBs & [124] \\
\hline FLASH & Mouse & $\mathrm{KO}$ & Embryonic lethal & {$[125]$} \\
\hline NELF E & HeLa cells & shRNA KD of $R D B P$ & $\begin{array}{l}\text { NELF complex proteins } \\
\text { Cell proliferation } \\
\text { Aberrant histone RNA processing }\end{array}$ & [73] \\
\hline HiNF-P & $\begin{array}{c}\text { Human } \\
\text { glioblastoma cells }\end{array}$ & $\begin{array}{c}\text { ASO and siRNA KD } \\
\text { of HINFP }\end{array}$ & $\begin{array}{l}\text { Histone } 4 \text { gene expression } \\
\text { RNA Pol II and NPAT histone } 4 \\
\text { promoter occupancy }\end{array}$ & [74] \\
\hline HiNF-P & Mouse & $\begin{array}{c}\text { Amorphic allele of } \\
\text { Hinfp }\end{array}$ & $\begin{array}{l}\text { Histone } 4 \text { gene expression } \\
\text { Embryonic lethal }\end{array}$ & [126] \\
\hline ZPR1 & HeLa cells & $\begin{array}{l}\text { siRNA and ASO KD } \\
\text { of ZPRI }\end{array}$ & $\begin{array}{l}\text { Mislocalization of SMN, NPAT, } \\
\text { coilin and Sm proteins } \\
\text { S phase block } \\
\text { Transcription }\end{array}$ & {$[75]$} \\
\hline
\end{tabular}


Table 2. Cont.

\begin{tabular}{|c|c|c|c|c|}
\hline $\begin{array}{c}\text { Nuclear Body } \\
\text { Component }\end{array}$ & $\begin{array}{l}\text { Model } \\
\text { System }\end{array}$ & $\begin{array}{l}\text { Experimental } \\
\text { Manipulation }\end{array}$ & Phenotype & References \\
\hline \multicolumn{5}{|c|}{ Histone Locus Body } \\
\hline \multicolumn{5}{|l|}{ Proteins } \\
\hline ZPR1 & Mouse & KO & Embryonic lethal & [117] \\
\hline Coilin & $\begin{array}{l}\text { Human breast } \\
\text { cancer cells }\end{array}$ & shRNA KD of COIL & No effect on HLBs & [124] \\
\hline Coilin & $\begin{array}{c}\text { Cultured mouse } \\
\text { embryonic } \\
\text { fibroblasts } \\
\end{array}$ & shRNA KD of Coil & No effect on HLBs & {$[124]$} \\
\hline Coilin & Fruit fly & $\begin{array}{l}\text { Amorphic alleles of } \\
\text { coil }\end{array}$ & $\begin{array}{l}\text { No CBs } \\
\text { No effect on HLBs } \\
\text { Viable and fertile } \\
\end{array}$ & {$[76]$} \\
\hline \multicolumn{5}{|l|}{ RNA } \\
\hline U7 RNA & Fruit fly & $\begin{array}{l}\text { Null alleles of } U 7 \\
\text { snRNA }\end{array}$ & $\begin{array}{l}\text { Aberrant histone pre-mRNA } \\
\text { processing } \\
\text { No effect on HLBs } \\
\text { No Lsm10 and Lsm11 localization } \\
\text { to HLBs } \\
\text { Viable, but sterile }\end{array}$ & {$[122,123,127]$} \\
\hline \multicolumn{5}{|l|}{ DNA } \\
\hline Histone locus & Fruit fly & $\begin{array}{c}\text { Histone locus } \\
\text { deletion mutant } \\
D f(2 L) D S 6 \\
\end{array}$ & Smaller proto-HLBs & {$[122,128]$} \\
\hline \multicolumn{5}{|l|}{ Paraspeckle } \\
\hline \multicolumn{5}{|l|}{ Proteins } \\
\hline NONO & HeLa cells & siRNA KD of $N O N O$ & Paraspeckles & [83] \\
\hline NONO & Mouse & $\begin{array}{l}\text { Chondrocyte lineage- } \\
\text { specific expression of } \\
\text { truncated murine } \\
\text { NONO }\end{array}$ & $\begin{array}{l}\text { Dwarfism } \\
\text { Chondrogenesis }\end{array}$ & [129] \\
\hline NONO & $\begin{array}{l}\text { Cultured mouse } \\
\text { chondrogenic cells }\end{array}$ & siRNA KD of Nono & $\begin{array}{l}\text { Sox9-dependent Col2al } \\
\text { promoter activity and expression }\end{array}$ & [129] \\
\hline NONO & $\begin{array}{c}\text { Cultured mouse } \\
\text { embryonic } \\
\text { fibroblasts } \\
\end{array}$ & siRNA KD of Nono & Circadian rhythm & [130] \\
\hline NONO & Fruit fly & $\begin{array}{c}\text { Hypomorphic allele } \\
\text { of nonA }\end{array}$ & Circadian rhythm & {$[130]$} \\
\hline PSP1 & HeLa cells & siRNA KD of $P S P C 1$ & No effect on paraspeckles & [83] \\
\hline SFPQ & HeLa cells & siRNA KD of $S F P Q$ & No paraspeckles & [83] \\
\hline
\end{tabular}


Table 2. Cont.

\begin{tabular}{|l|c|c|l|c|}
\hline $\begin{array}{c}\text { Nuclear Body } \\
\text { Component }\end{array}$ & $\begin{array}{c}\text { Model } \\
\text { System }\end{array}$ & $\begin{array}{c}\text { Experimental } \\
\text { Manipulation }\end{array}$ & \multicolumn{2}{|c|}{ Phenotype } \\
\hline Paraspeckle & \multicolumn{5}{|l|}{ References } \\
\hline RNAs & HeLa cells & $\begin{array}{c}\text { siRNA or ASO KD } \\
\text { of NEAT1 }\end{array}$ & No paraspeckles & {$[81-83,131]$} \\
\hline NEATl RNA & $\begin{array}{c}\text { Human } \\
\text { shRA KD of } \\
\text { NEATI RNA }\end{array}$ & $\begin{array}{l}\text { No paraspeckles } \\
\text { Normal circadian rhythm }\end{array}$ & {$[132]$} \\
\hline Neat1 RNA & Mouse & KO & $\begin{array}{l}\text { No paraspeckles } \\
\text { Viable and fertile }\end{array}$ & {$[133]$} \\
\hline Ctn RNA & $\begin{array}{c}\text { Cultured mouse } \\
\text { mammary tumor } \\
\text { and macrophage } \\
\text { cells }\end{array}$ & $\begin{array}{c}\text { ASO KD of } \\
\text { Ctn }\end{array}$ & $\begin{array}{l}\text { No effect on paraspeckles } \\
\text { Ctn RNA and Cat } 2 \text { mRNA }\end{array}$ & {$[79]$} \\
\hline
\end{tabular}

Abbreviations: ASO, antisense oligonucleotide; BrUTP, 5-bromouridine 5'-triphosphate; CB, Cajal body; DBA, Diamond-Blackfan anemia; DKC, dyskeratosis congenita; DRB; 5,6-dichloro-1- $\beta$-D-ribofuranosylbenzimidazole; EJC, exon junction complex; gem, Gemini of Cajal body; HLB, histone locus body; HSF, heat shock factor; IP, immunoprecipitation; iPSC, induced pluripotent stem cell; KD, knockdown; KO, knockout; LOF, loss of function; mRNA, messenger RNA; NELF, negative elongation factor; NPAT, nuclear protein ataxia telangiectasia locus; nSB, nuclear stress body; pre-mRNA, precursor messenger RNA; pre-rRNA, precursor ribosomal RNA; RNA Pol, RNA polymerase; rRNA, ribosomal RNA; scaRNA, small Cajal body-specific RNA; shRNA, short hairpin RNA; siRNA, small interfering RNA; SMA, spinal muscular atrophy; SMN, survival of motor neuron; snRNA, small nuclear RNA; snRNP, small nuclear ribonucleoprotein; SRSF, serine/arginine-rich splicing factor.

\subsubsection{Mechanisms of Gene Expression and the Nucleolus}

The nucleolus regulates gene expression by modulating protein production via ribosome biogenesis. Ribosome biogenesis is critical to cellular function, growth and response to stimuli. The multifunctional phosphoproteins, nucleophosmin and nucleolin, regulate ribosome biogenesis at several levels. Nucleophosmin specifically interacts with ribosomal DNA (rDNA) and regulates the transcription of rDNA as a histone chaperone [134]. Furthermore, it functions as the rate-limiting nuclear export chaperone for the precursor 40S (pre-40S) and precursor 60S (pre-60S) ribosomal subunits [14]. Nucleolin interacts with rDNA, maintains the open conformation of the rDNA genes, regulates the transcription of the rDNA genes and functions in rRNA processing $[15,135]$. The snoRNP complexes post-transcriptionally modify rRNA; these modifications affect the secondary structure that influences the stability, interactions and catalytic functionality of the rRNA. At least one study has demonstrated that a defect in the pseudouridylation of rRNAs leads to decreased ribosomal ligand binding and translational fidelity [85]. The biogenesis of ribosomes, therefore, requires the function of several proteins to transcribe rDNA, process pre-rRNA, assemble rRNA with ribosomal proteins and export the pre-40S and pre-60S ribosomal subunits.

In addition to the modulation of gene expression through ribosome biogenesis, the nucleolus modulates protein post-translational modifications, such as ubiquitination and SUMOylation. 
Ubiquitination of transcription termination factor 1 (TTF1) and p53 by ubiquitin ligase MDM2 regulates ribosome biogenesis and p53 regulation, respectively [136,137], and deubiquitination of the largest subunit of RNA Pol I by conserved yeast deubiquitinating enzyme, Ubp10, mediates RNA Pol I stability [138]. SUMOylation of NOP58 is critical for box C/D snoRNA binding and localization of newly transcribed snoRNAs to the nucleolus [139], and deSUMOylation of nucleophosmin by sentrin-specific protease 3 (SENP3) is needed for pre-rRNA processing [140].

Sequestration of proteins is another mechanism by which the nucleolus modulates expression of gene products. Proteins may be stabilized through sequestration of degradation factors to the nucleolus. For example, sequestration of ubiquitin ligases MDM2, and von Hippel-Lindau disease tumor suppressor (VHL) enhances the stability of their targets p53 and hypoxia-inducible factor 1 alpha (HIF1alpha), respectively [141,142]. Deactivation of a complex through the physical separation of its subunits has also been observed; tumor suppressor, p14ARF, inhibits the transcriptional activity of HIF1 through the sequestration of its alpha subunit to the nucleolus [143]. Finally, protein activity can be modulated by sequestration from the local environment in which it is active. For instance, the transcription repressor activity of DAXX is inhibited upon sequestration of DAXX to the nucleolus [144].

\subsubsection{Human Diseases Associated with the Nucleolus}

Several human disorders associate with mutations in genes encoding nucleolar proteins (Table 3). Mutations in genes encoding the two RNA Pol I subunits, POLR1C and POLR1D, and in the nucleolar protein Treacher Collins-Franceschetti syndrome 1 (TCOF1, also known as treacle) cause the craniofacial disorder, Treacher Collins syndrome (OMIM 248390, OMIM 613717 and OMIM 154500). Additionally, dysregulation of RNA Pol I transcription in nucleoli is frequently observed in cancer [145]. Mutations in genes encoding for the $40 \mathrm{~S}$ and $60 \mathrm{~S}$ ribosomal subunits lead to Diamond-Blackfan anemia (OMIM 105650, OMIM 610629, OMIM 612527, OMIM 612528, OMIM 612561, OMIM 612562, OMIM 612563, OMIM 613308, OMIM 613309 and OMIM 614900). Finally, mutations in $W R N$ and $B L M$, which encode nucleolar DNA helicases, cause Werner syndrome (OMIM 277700) and Bloom syndrome (OMIM 210900), respectively.

Table 3. Selected human diseases associated with mutations in genes encoding nuclear body components.

\begin{tabular}{|l|l|c|l|c|}
\hline Gene & Human Disease & $\begin{array}{c}\text { OMIM } \\
\text { No. }\end{array}$ & Phenotype & $\begin{array}{c}\text { Disease Gene } \\
\text { Identification References }\end{array}$ \\
\hline Nucleolus & \multicolumn{5}{|l|}{} \\
\hline TCOF1 & Treacher Collins syndrome 1 & 154500 & Craniofacial abnormalities & {$[146]$} \\
\hline POLR1D & Treacher Collins syndrome 2 & 613717 & Craniofacial abnormalities & {$[147]$} \\
\hline POLR1C & Treacher Collins syndrome 3 & 248390 & Craniofacial abnormalities & {$[147]$} \\
\hline RPS19 & Diamond-Blackfan anemia 1 & 105650 & Hypoplastic anemia & {$[148]$} \\
\hline RPS24 & Diamond-Blackfan anemia 3 & 610629 & Hypoplastic anemia & {$[149]$} \\
\hline RPS17 & Diamond-Blackfan anemia 4 & 612527 & Hypoplastic anemia & {$[150]$} \\
\hline RPL35A & Diamond-Blackfan anemia 5 & 612528 & Hypoplastic anemia & {$[151]$} \\
\hline RPL5 & Diamond-Blackfan anemia 6 & 612561 & Hypoplastic anemia & {$[152]$} \\
\hline RPL11 & Diamond-Blackfan anemia 7 & 612562 & Hypoplastic anemia & {$[152]$} \\
\hline
\end{tabular}


Table 3. Cont.

\begin{tabular}{|c|c|c|c|c|}
\hline Gene & Human Disease & $\begin{array}{l}\text { OMIM } \\
\text { No. }\end{array}$ & Phenotype & $\begin{array}{c}\text { Disease Gene } \\
\text { Identification References }\end{array}$ \\
\hline \multicolumn{5}{|l|}{ Nucleolus } \\
\hline RPS7 & Diamond-Blackfan anemia 8 & 612563 & Hypoplastic anemia & [152] \\
\hline RPS10 & Diamond-Blackfan anemia 9 & 613308 & Hypoplastic anemia & [153] \\
\hline$R P S 26$ & Diamond-Blackfan anemia 10 & 613309 & Hypoplastic anemia & [153] \\
\hline RPL26 & Diamond-Blackfan anemia 11 & 614900 & Hypoplastic anemia & [154] \\
\hline$W R N$ & Werner syndrome & 277700 & Premature aging syndrome & [155] \\
\hline$B L M$ & Bloom syndrome & 210900 & $\begin{array}{l}\text { Growth deficiency } \\
\text { Cancer predisposition }\end{array}$ & {$[156]$} \\
\hline \multicolumn{5}{|c|}{ Nuclear Speckle } \\
\hline PRPF3 & Retinitis pigmentosa 18 & 601414 & Retinal degeneration & [157] \\
\hline PRPF6 & Retinitis pigmentosa 60 & 613983 & $\begin{array}{l}\text { Retinal degeneration } \\
\text { pre-mRNA splicing }\end{array}$ & [158] \\
\hline PRPF8 & Retinitis pigmentosa 13 & 600059 & Retinal degeneration & [159] \\
\hline SNRNP200 & Retinitis pigmentosa 33 & 610359 & $\begin{array}{l}\text { Retinal degeneration } \\
\text { U U4/U6 snRNA } \\
\text { unwinding } \\
\end{array}$ & {$[160]$} \\
\hline EFTUD2 & $\begin{array}{l}\text { Mandibulofacial dysostosis, } \\
\text { Guion-Almeida type }\end{array}$ & 610536 & $\begin{array}{l}\text { Facial dysmorphism } \\
\text { Progressive microcephaly } \\
\text { Developmental delay } \\
\text { Speech delay }\end{array}$ & [161] \\
\hline$R B M 8 A$ & $\begin{array}{l}\text { Thrombocytopenia-absent radius } \\
\text { syndrome }\end{array}$ & 274000 & $\begin{array}{l}\text { Platelet reduction } \\
\text { Radial bone aplasia }\end{array}$ & [162] \\
\hline \multicolumn{5}{|c|}{ Transcription Factory } \\
\hline POLR1D & Treacher Collins syndrome 2 & 613717 & Craniofacial abnormalities & [147] \\
\hline POLRIC & Treacher Collins syndrome 3 & 248390 & Craniofacial abnormalities & [147] \\
\hline POLR3A & $\begin{array}{l}\text { Hypomyelinating } \\
\text { leukodystrophy } 7\end{array}$ & 607694 & $\begin{array}{l}\text { Hypomyelination } \\
\text { Motor dysfunction } \\
\pm \text { Abnormal dentition } \\
\pm \text { Hypogonadism }\end{array}$ & {$[163,164]$} \\
\hline POLR3B & $\begin{array}{l}\text { Hypomyelinating } \\
\text { leukodystrophy } 8\end{array}$ & 614381 & $\begin{array}{l}\text { Hypomyelination } \\
\text { Motor dysfunction } \\
\pm \text { Abnormal dentition } \\
\pm \text { Hypogonadism } \\
\end{array}$ & {$[164,165]$} \\
\hline MED12 & Lujan-Fryns syndrome & 309520 & $\begin{array}{l}\text { Marfanoid habitus } \\
\text { Intellectual disability }\end{array}$ & [166] \\
\hline MED12 & Opitz-Kaveggia syndrome & 305450 & $\begin{array}{l}\text { Facial dysmorphism } \\
\text { Hypotonia } \\
\text { Intellectual disability }\end{array}$ & [167] \\
\hline MED17 & $\begin{array}{l}\text { Postnatal progressive } \\
\text { microcephaly with seizures and } \\
\text { brain atrophy }\end{array}$ & 613668 & $\begin{array}{l}\text { Progressive microcephaly } \\
\text { Brain atrophy } \\
\text { Developmental retardation }\end{array}$ & [168] \\
\hline MED23 & $\begin{array}{l}\text { Mental retardation, } \\
\text { autosomal recessive } 18\end{array}$ & 614249 & Intellectual disability & [169] \\
\hline
\end{tabular}


Table 3. Cont.

\begin{tabular}{|c|c|c|c|c|}
\hline Gene & Human Disease & $\begin{array}{l}\text { OMIM } \\
\text { No. }\end{array}$ & Phenotype & $\begin{array}{c}\text { Disease Gene } \\
\text { Identification References }\end{array}$ \\
\hline \multicolumn{5}{|c|}{ Transcription Factory } \\
\hline MED25 & $\begin{array}{l}\text { Charcot-Marie-Tooth disease, } \\
\text { type } 2 \mathrm{~B} 2\end{array}$ & 605589 & $\begin{array}{l}\text { Distal muscle weakness } \\
\text { and atrophy } \\
\text { Sensory loss }\end{array}$ & {$[170]$} \\
\hline$E R C C 2$ & $\begin{array}{l}\text { Xeroderma pigmentosum, } \\
\text { group D }\end{array}$ & 278730 & $\begin{array}{l}\text { Sun sensitivity } \\
\text { Increased risk for cancer }\end{array}$ & {$[171]$} \\
\hline$E R C C 2$ & $\begin{array}{l}\text { Cerebrooculofacioskeletal } \\
\text { syndrome } 2\end{array}$ & 610756 & $\begin{array}{l}\text { Microcephaly } \\
\text { Ocular abnormalities } \\
\text { Multiple joint contractures } \\
\text { Dysmorphic features }\end{array}$ & {$[172]$} \\
\hline$E R C C 2$ & Trichothiodystrophy & 601675 & $\begin{array}{l}\text { Brittle hair and nails } \\
\text { Ichthyotic skin } \\
\text { Growth delay } \\
\text { Intellectual disability }\end{array}$ & {$[173]$} \\
\hline$E R C C 3$ & $\begin{array}{l}\text { Xeroderma pigmentosum, } \\
\text { group B }\end{array}$ & 610651 & $\begin{array}{l}\text { Sun sensitivity } \\
\text { Increased risk for cancer }\end{array}$ & {$[174]$} \\
\hline$E R C C 3$ & Trichothiodystrophy & 601675 & $\begin{array}{l}\text { Brittle hair and nails } \\
\text { Ichthyotic skin } \\
\text { Growth delay } \\
\text { Intellectual disability }\end{array}$ & {$[175]$} \\
\hline GTF2H5 & Trichothiodystrophy & 601675 & $\begin{array}{l}\text { Brittle hair and nails } \\
\text { Ichthyotic skin } \\
\text { Growth delay } \\
\text { Intellectual disability }\end{array}$ & {$[176]$} \\
\hline \multicolumn{5}{|c|}{ Cajal Body } \\
\hline SMN1 & $\begin{array}{l}\text { Spinal muscular atrophy, type I } \\
\text { Spinal muscular atrophy, type II } \\
\text { Spinal muscular atrophy, type III } \\
\text { Spinal muscular atrophy, type IV } \\
\end{array}$ & $\begin{array}{l}253300 \\
253550 \\
253400 \\
271150 \\
\end{array}$ & $\begin{array}{l}\text { Lower motor neuron } \\
\text { degeneration } \\
\text { SMN protein } \\
\text { Gems } \\
\end{array}$ & {$[177]$} \\
\hline$D K C 1$ & $\begin{array}{l}\text { Dyskeratosis congenita, X- } \\
\text { linked }\end{array}$ & 305000 & $\begin{array}{l}\text { Nail dystrophy } \\
\text { Lacy skin pigmentation } \\
\text { Oral leukoplakia } \\
\text { TERC RNA } \\
\text { Telomerase assembly } \\
\text { Telomerase activity }\end{array}$ & {$[178]$} \\
\hline$D K C 1$ & Hoyeraal-Hreidarsson syndrome & 300240 & $\begin{array}{l}\text { Growth delay } \\
\text { Immunodeficiency } \\
\text { Cerebellar hypoplasia } \\
\end{array}$ & [179] \\
\hline$N H P 2$ & $\begin{array}{l}\text { Dyskeratosis congenita, } \\
\text { autosomal recessive } 2\end{array}$ & 613987 & $\begin{array}{l}\text { Nail dystrophy } \\
\text { Lacy skin pigmentation } \\
\text { Oral leukoplakia } \\
\text { Telomerase assembly }\end{array}$ & {$[180]$} \\
\hline
\end{tabular}


Table 3. Cont.

\begin{tabular}{|c|c|c|c|c|}
\hline Gene & Human Disease & $\begin{array}{l}\text { OMIM } \\
\text { No. }\end{array}$ & Phenotype & $\begin{array}{c}\text { Disease Gene } \\
\text { Identification References }\end{array}$ \\
\hline \multicolumn{5}{|c|}{ Cajal Body } \\
\hline NOP10 & $\begin{array}{l}\text { Dyskeratosis congenita, } \\
\text { autosomal recessive } 1\end{array}$ & 224230 & $\begin{array}{l}\text { Nail dystrophy } \\
\text { Lacy skin pigmentation } \\
\text { Oral leukoplakia } \\
\text { Telomerase assembly }\end{array}$ & {$[181]$} \\
\hline TERT & $\begin{array}{l}\text { Dyskeratosis congenita, } \\
\text { autosomal dominant } 2 \\
\text { Dyskeratosis congenita, } \\
\text { autosomal recessive } 4\end{array}$ & 613989 & $\begin{array}{l}\text { Nail dystrophy } \\
\text { Lacy skin pigmentation } \\
\text { Oral leukoplakia } \\
\text { Telomerase activity }\end{array}$ & {$[182,183]$} \\
\hline WRAP53 & $\begin{array}{l}\text { Dyskeratosis congenita, } \\
\text { autosomal recessive } 3\end{array}$ & 613988 & $\begin{array}{l}\text { Nail dystrophy } \\
\text { Lacy skin pigmentation } \\
\text { Oral leukoplakia } \\
\text { Telomerase localization } \\
\text { to CBs }\end{array}$ & {$[184]$} \\
\hline TERC & $\begin{array}{l}\text { Dyskeratosis congenita, } \\
\text { autosomal dominant } 1\end{array}$ & 127550 & $\begin{array}{l}\text { Nail dystrophy } \\
\text { Lacy skin pigmentation } \\
\text { Oral leukoplakia }\end{array}$ & [185] \\
\hline \multicolumn{5}{|c|}{ Gemini of Cajal Body } \\
\hline SMN1 & $\begin{array}{l}\text { Spinal muscular atrophy, type I } \\
\text { Spinal muscular atrophy, type II } \\
\text { Spinal muscular atrophy, type III } \\
\text { Spinal muscular atrophy, type IV }\end{array}$ & $\begin{array}{l}253300 \\
253550 \\
253400 \\
271150\end{array}$ & $\begin{array}{l}\text { Lower motor neuron } \\
\text { degeneration } \\
\text { SMN protein } \\
\text { Gems }\end{array}$ & {$[177]$} \\
\hline
\end{tabular}

Abbreviations: CB, Cajal body; gem, Gemini of Cajal body; OMIM, Online Mendelian Inheritance in Man; pre-mRNA, precursor messenger RNA; SMN, survival of motor neuron; snRNA, small nuclear RNA.

\subsection{Nuclear Speckle}

\subsubsection{Discovery}

First described as grumos hialinas or transparent lumps by Santiago Ramón y Cajal in 1910 [186] and subsequently detected by electron microscopy and immunofluorescence [187,188], nuclear speckles or interchromatin granule clusters have a speckled distribution in the interchromatin regions of the nucleus. The similar distribution of spliceosomal snRNPs was a clue to the function of nuclear speckles in pre-mRNA splicing [189-191] and integration of transcription with pre-mRNA splicing [192].

\subsubsection{Key Components}

Most constituents in the nuclear speckle are components of the spliceosome and function in pre-mRNA splicing; these include the spliceosomal snRNAs and several associated protein factors that comprise the snRNPs [33,34] (Table 1). Other constituents include heteronuclear RNPs (hnRNPs), cleavage and polyadenylation factors, protein kinases, such as CDC-like kinase (CLK), members of the exon junction complex (EJC) and structural proteins [33,34]. Two abundant RNAs in nuclear speckles are 
the long non-coding RNA (ncRNA) metastasis-associated lung adenocarcinoma transcript 1 (MALAT1) and polyadenylated (poly(A)+) RNA [38,39].

\subsubsection{Functions of Key Components}

Members of the serine (S)/arginine (R)-rich splicing factor (SRSF) family, which are the predominant splicing factors found in the nuclear speckle [32], participate in constitutive and alternative splicing, as well as in transcription [193], nonsense-mediated mRNA decay (NMD), mRNA translation and genome stability [194]. They may also contribute to the integrity of the nuclear speckle, since RNA interference (RNAi)-mediated knockdown of SRSF1 or SRSF2 decreases localization of other pre-mRNA processing factors to nuclear speckles, enlarges nuclear speckles and decreases the transcription of some genes [89] (Table 2). Members of the spliceosomal snRNPs are involved in pre-mRNA splicing, while members of the cleavage and polyadenylation specificity factor (CPSF) complex facilitate pre-mRNA 3' end processing (Table 1).

Proteins, mago nashi homologue $(\mathrm{MAGOH})$, eukaryotic initiation factor 4A III (eIF4AIII), RNA-binding protein S1 (RNPS1), Y14 and Aly/REF, which are members of the EJC, function in RNA surveillance, NMD and, in conjunction with nuclear speckle protein, RAE1, the nuclear export of mRNA [195] (Table 1). RNAi-mediated knockdown of Aly/REF decreases nuclear mRNA export and causes increased poly(A)+ RNA accumulation in nuclear speckles [94] (Table 2).

The long ncRNA MALAT1, which is retained in the nucleus, binds and regulates SRSF proteins and, thereby, modulates alternative splicing [91]. Despite this, however, Malat1-null mice are viable and fertile, and the cells and tissues tested from these animals have appropriately localized nuclear speckle proteins [95]. In contrast, knockdown of MALAT1 in HeLa cells causes aberrant alternative splicing, decreased localization of pre-mRNA processing factors to nuclear speckles and a distorted ratio of dephosphorylated to phosphorylated pools of SRSF proteins [91]. Further studies are required to delineate this apparent functional difference.

\subsubsection{Mechanisms of Gene Expression and the Nuclear Speckle}

The nuclear speckle regulates gene expression by possibly regulating transcription directly and via post-transcriptional mechanisms. Observations supporting a direct effect on transcription include (1) the enrichment of the periphery of nuclear speckles for the elongating form of RNA Pol II $[36,196]$, (2) the facilitation of transcriptional elongation by the nuclear speckle protein, SRSF2 [193], and (3) the concurrent splicing and transcription of $80 \%$ of pre-mRNA [192]. Observations supporting a post-transcriptional effect on gene expression include (1) the modulation of constitutive and alternative splicing [94,192] and (2) the modulation of nuclear export, mRNA surveillance and post-translational modification. Exemplifying the latter, the nuclear speckle kinase, CLK, phosphorylates SRSF proteins to alter their intranuclear distribution [35], pre-mRNA splicing efficiency [197] and recruitment to transcription sites [198]. Lastly, nuclear speckles likely integrate transcription with mRNA export, since the nuclear speckle proteins, Aly/REF and U2AF65-associated protein $56 \mathrm{kDa}$ (UAP56), function in both transcription and mRNA export [199].

Nuclear speckles may also directly modulate gene expression through interaction with the RNA Pol II complex [194], even though transcription does not occur within nuclear speckles [200]. 


\subsubsection{Human Diseases Associated with the Nuclear Speckle}

Disorders associated with mutations in genes encoding nuclear speckle components include retinitis pigmentosa (OMIM 600138, OMIM 600059, OMIM 601414, OMIM 610359 and OMIM 613983), mandibulofacial dysostosis with microcephaly (OMIM 610536) and thrombocytopenia-absent radius syndrome (OMIM 274000) (Table 3). Several of these mutations likely affect spliceosome activity and pre-mRNA splicing $[158,160]$ (Table 3).

\subsection{Nuclear Stress Body}

\subsubsection{Discovery}

First identified as foci of heat shock factor 1 in heat-stressed cells [40,201,202], nuclear stress bodies transiently form in response to various cellular stresses, such as heat shock, ultraviolet light and chemical agents, such as heavy metals, the amino acid analog azetidine and proteasome inhibitors. Although nuclear stress bodies have only been detected in primate cells [203], analogous stress-inducible structures have been observed in the cells of Drosophila melanogaster and Caenorhabditis elegans [204,205] (Table 4).

\subsubsection{Key Components of the Nuclear Stress Body}

The nuclear stress body consists of both protein and non-protein components that modulate gene expression via transcription and RNA splicing. The protein components include the heat shock transcription factors, heat shock factor 1 (HSF1) and heat shock factor 2 (HSF2), scaffold attachment factor B (SAF-B), Src-associated in mitosis $68 \mathrm{kDa}$ protein (Sam68) and the SRSF family members, SRSF1, SRSF7 and SRSF9 [40-43,201,206] (Table 1). RNA Pol II is also present in nuclear stress bodies [44]. The one identified non-protein component is the long satellite III ncRNA [44] (Table 1).

\subsubsection{Functions of Key Components}

The heat shock transcription factors, HSF1 and HSF2, participate in the cellular response to stress. Present as inactive monomers in the cytoplasm, these transcription factors trimerize and translocate to the nucleus upon cellular stress [40]. They bind to heat shock elements (HSEs) present in the promoters of target genes and activate gene expression [207]. In addition to the genes encoding the heat shock proteins (HSPs), satellite III ncRNA, which is transcribed from the pericentric heterochromatic 9p12 locus, is also targeted [44,208]. In human cells, knockdown of HSF1 impeded heat induction of nuclear stress bodies, HSF2 binding to DNA and satellite III transcription, whereas knockdown of HSF2 had no effect on HSF1 localization to nuclear stress bodies and increased satellite III transcription [98] (Table 2). Thus, HSF2 binding to DNA is HSF1-dependent, and both HSF1 and HSF2 are required for the regulated expression of target genes.

SAF-B is an hnRNP that is involved in the transcriptional regulation of the gene encoding the heat shock protein, Hsp27 [209], as well as repression of estrogen receptor alpha-mediated transcription [210]. 
Table 4. Conservation of nuclear bodies across species.

\begin{tabular}{|c|c|c|c|c|c|c|c|c|}
\hline Nuclear Body & $\begin{array}{c}\text { Human } \\
\text { Homo sapiens }\end{array}$ & $\begin{array}{c}\text { Mouse } \\
\text { Mus } \\
\text { musculus }\end{array}$ & $\begin{array}{c}\text { African } \\
\text { clawed frog } \\
\text { Xenopus laevis }\end{array}$ & $\begin{array}{l}\text { Zebrafish } \\
\text { Danio rerio }\end{array}$ & $\begin{array}{c}\text { Fruit fly } \\
\text { Drosophila } \\
\text { melanogaster }\end{array}$ & $\begin{array}{c}\text { Nematode } \\
\text { Caenorhabditis } \\
\text { elegans }\end{array}$ & $\begin{array}{c}\text { Budding yeast } \\
\text { Saccharomyces } \\
\text { cerevisiae }\end{array}$ & References \\
\hline Nucleolus & + & + & + & + & + & + & $+^{1}$ & {$[211-215]$} \\
\hline Nuclear speckle & + & + & $t^{2}$ & ND & + & ND & - & [216-219] \\
\hline Nuclear stress body & + & - & ND & ND & $-{ }^{3}$ & $-{ }^{4}$ & ND & {$[203-205]$} \\
\hline Transcription factory & + & + & ND & ND & ND & ND & ND & {$[99,220]$} \\
\hline Cajal body & + & + & -5 & + & + & ND & $+^{6}$ & {$[71,216,221-224]$} \\
\hline Gemini of Cajal body & + & + & ND & ND & $-{ }^{7}$ & ND & ND & {$[60,225,226]$} \\
\hline Histone locus body & + & ND & $+^{8}$ & -9 & + & ND & ND & {$[71,77,223,227,228]$} \\
\hline Paraspeckle & + & + & ND & ND & ND & ND & ND & {$[78,79]$} \\
\hline
\end{tabular}

Determination of the presence or absence of a nuclear body is based on the detection of bona fide, conserved, endogenous nuclear body markers in cultured cells or tissue of the species of interest. Studies that require further experimental validation have been noted. Abbreviations: + , presence of the nuclear body in the species of interest; -, absence of the nuclear body in the species of interest; ND, not determined. ${ }^{1}$ The morphological, biochemical and electron microscopic studies demonstrating that the dense crescent in yeast is equivalent to the nucleolus were first performed in Saccharomyces carlsbergensis; ${ }^{2}$ also known as the B snurposome in Xenopus laevis; ${ }^{3}$ although nuclear stress bodies have not been observed in Drosophila melanogaster, the induction of hsr $\omega$ transcripts and the formation of omega speckles upon heat shock is similar to the satellite III transcripts and nuclear stress bodies in human cells, respectively; ${ }^{4}$ nuclear stress granule-like structures have been observed in Caenorhabditis elegans upon expression of physiological levels of a fluorescently tagged HSF1 fusion protein; ${ }^{5}$ Xenopus laevis have Cajal body-like pearls that contain coilin and scaRNAs; however, they do not contain splicing snRNAs and are specifically associated with RNA polymerase III loci, unlike Cajal bodies in other species; ${ }^{6}$ also known as the nucleolar body in Saccharomyces cerevisiae; ${ }^{7}$ Gemini of Cajal bodies have been observed in Drosophila melanogaster larvae upon constitutive overexpression of a fluorescently tagged Gemin3 fusion protein; ${ }^{8}$ also known as the $\mathrm{C}$ snurposome in Xenopus laevis; ${ }^{9}$ nuclear bodies enriched for histone locus body components, U7 snRNA and LSm11, and deficient for coilin have been observed in Danio rerio embryos upon injection of messenger RNA encoding fluorescently tagged zebrafish coilin or LSm11 and in vitro transcribed fluorescently labeled mouse $U 7$ snRNA. However, it is unknown whether these nuclear bodies also co-localize with the histone gene locus. 
SRSF1, SRSF7 and SRSF9 participate in both constitutive and alternative splicing of pre-mRNA [197,229]. Additionally, SRSF1 processes microRNA [230]. The SRSF proteins have overlapping and distinct functions, differential expression and differential sequestration to nuclear stress bodies [43,197,231,232]. The alternative splicing regulator, Sam68, also accumulates in nuclear stress bodies upon cellular stress and likely mediates alternative splicing of transcripts in the nuclear stress body [233]

The satellite III transcripts are ncRNAs specific to nuclear stress bodies [44,234]. After being transcribed from pericentric heterochromatin at the $9 \mathrm{q} 12$ locus upon cellular stress, they remain associated with this genetic locus and are integral to the nuclear stress body that forms at the 9q12 locus [44,234]. The satellite III transcripts are required for the localization of proteins, such as SRSF1 and SRSF9, to the nuclear stress body [234]. Furthermore, the overexpression of satellite III transcripts has been shown to initiate the formation of nuclear stress bodies [235].

\subsubsection{Mechanisms of Gene Expression and the Nuclear Stress Body}

Although nuclear stress bodies sequester factors that regulate expression of genes involved in the stress response, the role of nuclear stress bodies themselves in gene expression has not been delineated. Besides the sequestration of transcription and RNA processing factors, three observations suggest a role in the modulation of gene expression. First, RNA Pol II and acetylated histones localize to nuclear stress bodies following stress [44]. Second, the nuclear stress protein, HSF1, controls genome-wide histone deacetylation upon heat stress [236]. Third, the splicing factors associated with nuclear stress bodies have been implicated in alternative splicing [233].

\subsubsection{Human Diseases Associated with the Nuclear Stress Body}

No human diseases have been described for mutations in genes encoding for nuclear stress body proteins or RNAs.

\subsection{Transcription Factory}

\subsubsection{Discovery}

Transcription factories were first observed and analyzed through biochemical studies and fluorescence and electron microscopy of the RNA polymerases and their nascent transcripts in HeLa cells $[45,99]$. These studies revealed that the RNA polymerases, and their nascent transcripts, are not diffusely scattered throughout the nucleus, but rather, are concentrated in a few thousand sites where transcription and RNA processing occur [45,99]. Although studies have provided evidence for stationary RNA polymerases and the existence of transcription factories [237], the recognition of transcription factories as a canonical nuclear body remains controversial. However, given their relevance to the regulation of gene expression, we review transcription factories. 


\subsubsection{Key Components of the Transcription Factory}

The three RNA polymerases are the defining components for their respective transcription factories. Other associated proteins include general transcription factors, the mediator complex, gene-specific regulatory factors, chromatin remodeling proteins, helicases, nucleic acid-binding proteins, RNPs and structural proteins [46] (Table 1). Transcription factories are, however, more than the simple co-localization of proteins, since they remain intact upon nucleolytic removal of chromatin and detergent extraction and in the absence of transcription [99,238,239].

\subsubsection{Gene Regulatory Functions of Key Components}

The RNA polymerases and the general transcription factors comprise the machinery that allow for the transcription of genes. Gene-specific regulatory factors, such as transcriptional activators and repressors, control the expression of specific genes through interaction with the gene of interest. Chromatin remodeling proteins, in turn, modify the DNA accessibility to those transcription factors.

\subsubsection{Mechanisms of Gene Expression and the Transcription Factory}

Transcription factories regulate gene expression by mediating transcription, concentrating the RNA polymerases and factors required for efficient transcription [240], coupling transcription with RNA processing [241] and modulating genomic structure [86].

\subsubsection{Human Diseases Associated with the Transcription Factory}

Several disorders have been described for mutations in genes encoding transcription factory components (Table 3). Treacher Collins syndrome is associated with mutations of POLR1C and POLR1D (OMIM 248390 and OMIM 613717), and hypomyelinating leukodystrophy is associated with mutations of POLR3A and POLR3B (OMIM 607694 and OMIM 614381). No disorders have been associated with mutations of genes encoding RNA Pol II subunits. Mutations in genes encoding the mediator complex and general transcription factors cause congenital malformations, intellectual disability and features of defective DNA repair. Mediator complex mutations have been associated with Lujan-Fryns (OMIM 309520) and Opitz-Kaveggia (OMIM 305450) syndromes, postnatal progressive microcephaly with seizures and brain atrophy (OMIM 613668), mental retardation autosomal recessive 18 (OMIM 614249) and Charcot-Marie-Tooth disease type 2B2 (OMIM 605589). Mutations of the general transcription factor II H complex cause xeroderma pigmentosum group D (OMIM 278730) and group B (OMIM 610651), cerebrooculofacioskeletal syndrome 2 (OMIM 610756) and trichothiodystrophy (OMIM 601675).

\subsection{Cajal Body}

\subsubsection{Discovery}

Cajal bodies, also known as coiled bodies, are named after their discoverer, Santiago Ramón y Cajal [221], and are one of the first non-nucleolar nuclear bodies observed. Since its first sighting in the vertebrate neuron, Cajal bodies have been identified in tissues of diverse organisms, 
including vertebrates, invertebrates and plants [242]. Subsequent to the discovery of the Cajal body marker, coilin, understanding of the Cajal body and its role in regulating gene expression has accelerated [47,48,242-244].

\subsubsection{Key Components}

The Cajal body is a site for the modification of small nuclear RNAs (snRNAs) and snoRNAs, as well as for the assembly and trafficking of RNPs. In addition to coilin, the Cajal body is enriched in spliceosomal small nuclear RNPs (snRNPs), snoRNPs, the telomerase RNP and in the factors that assemble and mature RNPs, as well as the survival of the motor neurons (SMN) complex [50,57,242,245] (Table 1). The multiprotein Integrator complex, which processes the 3' end of snRNAs [246] and maintains Cajal body integrity [247], may also be a member of the Cajal body [247].

\subsubsection{Functions of Key Components}

Coilin, an abundant Cajal body protein of unknown function, interacts with several Cajal body components [248-250] and likely contributes to telomerase RNA biogenesis and snRNA processing [249,251]. Coilin deficiency is detrimental to Cajal body formation, localization of Cajal body proteins and viability of some model organisms (Table 2). Mediators of spliceosomal snRNP biogenesis also reside in the Cajal body; these include the small Cajal body-specific RNPs (scaRNPs), which direct the 2'-O-methylation and pseudouridylation of the snRNAs [56], and the SMN complex, which facilitates the nuclear import and localization of snRNAs and Sm proteins, as well as their assembly into spliceosomal snRNPs [61] (Table 1). Maturation of spliceosomal snRNPs in the Cajal body occurs prior to deposition of snRNPs in the nuclear speckle [252-254]. Similar to the snRNPs, many snoRNPs also assemble and mature in the Cajal body prior to their transport to the nucleolus [50,255]. Members of the telomerase RNP complex found in the Cajal body include the proteins, dyskerin, GAR1, NHP2, NOP10, telomerase reverse transcriptase (TERT), telomerase Cajal body protein 1 (TCAB1), and the telomerase RNA component (TERC) RNA [51-54] (Table 1). Deficiency of these components leads to reduced assembly, activity and/or localization of the telomerase RNP in the Cajal body and also to decreased telomere synthesis and loss of self-renewal [54,105,184,256] (Table 2).

\subsubsection{Mechanisms of Gene Expression and the Cajal Body}

snRNP biogenesis is one mechanism by which the Cajal body regulates gene expression. The Cajal body mediates snRNP biogenesis at many levels, including snRNA post-transcriptional modification, snRNA transcription and snRNP assembly. The scaRNPs of the Cajal body mediate the post-transcriptional modifications of 2'-O-methylation and pseudouridylation of snRNA [56]. The functional significance of the 2'-O-methylation and pseudouridylation of snRNA and snoRNAs is unclear; however, they likely affect the secondary structure of the RNAs and, thereby, their stability, RNA interactions, protein interactions and catalytic function [257,258]. Implicating Cajal bodies in snRNA gene expression, Cajal bodies co-localize with snRNA genes and transcripts [259-261]. Suggesting that the Cajal body is also involved in the processing of the spliceosomal snRNAs, coilin 
has been shown to have RNase activity with the $U 2$ snRNA primary transcript in vitro, and knockdown of coilin abrogates this activity [251]. Finally, the Cajal body participates in the assembly of snRNPs [253,262] and, thereby, indirectly contributes to precursor messenger RNA (pre-mRNA) splicing.

The Cajal body also facilitates the biogenesis and localization of another RNP, the telomerase complex. The telomerase complex is required for telomere synthesis. Evidence suggesting a role for the Cajal body in telomere maintenance includes the Cajal body-dependent assembly and localization of the telomerase complex to the telomeres during the S phase [54,105,263-266], the failure of pluripotent stem cells derived from dyskeratosis congenita patients with TCAB1 mutations to lengthen telomeres [105] and the potential processing of telomerase RNA by coilin [249].

\subsubsection{Human Diseases Associated with the Cajal Body}

Although Cajal body dysfunction has not been definitively implicated in human disease, mutations of several Cajal body components have been (Table 3). Functional deficiency of SMN1 is the molecular cause of spinal muscular atrophy (SMA) (OMIM 253300, OMIM 253550, OMIM 253400 and OMIM 271150) [107,177], a degenerative disorder of spinal cord motor neurons [267,268]. Mutations in genes encoding for telomerase complex members lead to the premature aging disorder, dyskeratosis congenita (OMIM 305000, OMIM 613987, OMIM 224230, OMIM 613989, 613988 and OMIM 127550).

\subsection{Gemini of Cajal Body}

\subsubsection{Discovery}

In a study of the subcellular localization of the SMN1 protein, Liu and colleagues observed a novel nuclear structure similar in size, number, response to metabolic conditions and cell cycle behavior to Cajal bodies [60]. However, because it lacked the coilin protein characteristic of Cajal bodies, it was named the Gemini of Cajal body (also known as gems) [60].

\subsubsection{Key Components of the Gemini of Cajal Body}

The identified components of gems include the SMN complex and ZPR1 (Table 1). The SMN complex consists of the SMN1 protein (also known as GEMIN1) and the gem-associated proteins 2-8 (GEMIN2-8).

\subsubsection{Functions of Key Components}

The SMN complex is required for spliceosomal snRNP biogenesis [61], as well as for transcription [269,270] and translation [271]. The gem-associated proteins, GEMIN2-8, also found in the Cajal body, are integral to the SMN complex and interact with other members of the SMN complex and/or the Sm proteins. GEMIN5 defines the specificity of the complex through the recognition of snRNAs [272]. Based on RNAi-mediated knockdown studies, the other GEMIN proteins participate in spliceosomal snRNP assembly and recruitment of other SMN complex members [110,111] (Table 2). 
ZPR1, a highly conserved protein [273,274], is critical for viability in fission and budding yeast and in mice $[68,117,273]$. It interacts with and is required for the localization of SMN $[68,117,273]$. The interaction between ZPR1 and SMN is disrupted in SMA patient tissues, and mice heterozygous for Zprl have motor defects, progressive motor neuron degeneration and mislocalization of the SMN protein [68,118] (Table 2).

\subsubsection{Mechanisms of Gene Expression and the Gemini of Cajal Body}

The precise function of gems is unknown; however, gems may be the nuclear domain responsible for further maturation, storage or recycling of snRNPs. Gems associate with Cajal bodies, and translocation of SMN between the two is mediated, at least in part, by post-translational modifications of coilin [275]. Methylation of the coilin arginine (R)- and glycine (G)-rich (RG) box motif increases its affinity for SMN, thereby, localizing SMN complexes to Cajal bodies; conversely, hypomethylation of the coilin RG box motif decreases its affinity for SMN, releasing SMN complexes to gems [275]. This dynamic molecular switch may represent an alternative pathway for snRNP biogenesis in gems and have downstream effects on pre-mRNA splicing. Further studies delineating additional gem components, their functions and their relation to Cajal bodies are necessary to address these issues.

\subsubsection{Human Diseases Associated with the Gemini of Cajal Body}

Aside from spinal muscular atrophy, which was discussed above in the section on Cajal bodies, no human diseases have been specifically attributed to gems. The reduction of both SMN protein and the number of gems correlates with the clinical severity of SMA patients [107,108] (Table 3). Within model organisms, SMN deficiency also reduces the numbers of gems and alters spliceosomal snRNP biogenesis, pre-mRNA splicing and tissue-specific snRNA composition [110-115,276] (Table 2).

\subsection{Histone Locus Body}

\subsubsection{Discovery}

Searching for a vertebrate Cajal body equivalent in Drosophila melanogaster, Liu and colleagues found a nuclear body containing canonical Cajal body components that consistently co-localized with the histone gene locus [71]. Subsequent studies also identified these in Xenopus laevis and human nuclei, suggesting a conserved distinct nuclear compartment (Table 4). They therefore named this compartment the histone locus body [77,227,228].

\subsubsection{Key Components of the Histone Locus Body}

The histone locus body components facilitate replication-dependent histone gene expression (Table 1). Components dedicated to this function are the nuclear protein, ataxia-telangiectasia locus (NPAT) protein, the stem-loop binding protein (SLBP), the U7 spliceosomal snRNP-specific components, like Sm proteins, LSm10 and LSm11, and the U7 spliceosomal snRNA, as well as FLICE-associated huge protein (FLASH) [69-71]. Components not dedicated solely to replication-dependent histone gene 
expression include members of the negative elongation factor (NELF) complex, histone nuclear factor $\mathrm{P}$ (HiNF-P), zinc finger protein 1 (ZPR1) and coilin [70,73-76].

\subsubsection{Functions of Key Components}

During the $\mathrm{S}$ phase of the cell cycle, the replication-dependent histone genes are transcribed into RNAs that have a 3' untranslated region (UTR) with a highly conserved RNA hairpin element in lieu of a poly(A) tail. The histone locus body components contribute to the transcription, RNA processing, export, translation and degradation of the replication-dependent histone genes by linking their expression to the cell cycle. Cyclin E/Cdk2, which regulates the G1/S transition, phosphorylates the histone body component, NPAT, following its localization within the histone locus body by a ZPR1-dependent process $[69,75]$. Phosphorylated NPAT, in turn, activates replication-dependent histone gene expression by recruiting transcriptional activators to the histone gene promoters $[69,74,124]$. In cultured cells, dysregulation of NPAT or ZPR1 decreases histone gene expression, alters histone locus body protein localization, decreases the fidelity of histone RNA processing and impedes cell cycle progression; deficiency of either protein causes embryonic lethality in mice [117,119] (Table 2).

Cell cycle regulation of SLBP expression also contributes to the cell cycle-dependent expression of the replication-dependent histone genes; SLBP is increased in expression shortly prior to the S phase, highly expressed during the S phase and degraded at the end of the S phase $[69,277]$. Processing the $3^{\prime}$ ends of histone pre-mRNAs within the histone locus body requires SLBP, the U7 snRNP, the NELF complex and the histone pre-mRNA cleavage complex (HCC), which is comprised of FLASH, LSm11, symplekin, cleavage stimulation factor 64 (CSTF64) and all subunits of the CPSF complex [277]. SLBP binds the conserved RNA hairpin element at the 3' UTR and stabilizes the interaction of histone pre-mRNA with the U7 snRNP; SLBP also participates in the nuclear export, translation and degradation of histone mRNA [120,278,279]. After binding the histone downstream element (HDE) in the 3' UTR, the U7 snRNP and SLBP recruit the HCC, and the CPSF73 endonuclease cleaves the 3' end of the histone pre-mRNA. Deficiency of SLBP, the U7 snRNP or the NELF complex causes aberrant histone RNA 3 ' end processing, but does not affect the formation of histone locus bodies (Table 2).

Coilin, the classical marker of Cajal bodies, is also found in histone locus bodies [76]. Its function within histone locus bodies is currently undefined. RNAi-mediated knockdown and null alleles of coilin orthologues in mammalian cells and Drosophila, respectively, have no effect on the formation and function of histone locus bodies [76,124].

The invariant co-localization of histone locus bodies with the histone locus is a defining feature of this nuclear body. The histone locus itself, therefore, may be required for its structural integrity, and in fact, smaller histone locus bodies have been observed in Drosophila embryos deficient for the histone locus [122] (Table 2).

\subsubsection{Mechanisms of Gene Expression and the Histone Locus Body}

The histone locus body regulates expression of replication-dependent histone genes by concentrating the required protein complexes and RNA components at the histone gene locus during the appropriate phase of the cell cycle. This is accomplished, at least in part, through the cell cycle 
regulation of NPAT and SLBP [277]. Consequently, replication-dependent histone gene expression is coordinated with DNA synthesis.

\subsubsection{Human Diseases Associated with the Histone Locus Body}

No human diseases have been described for mutations in genes encoding for proteins or RNAs that comprise histone locus bodies.

\subsection{Paraspeckle}

\subsubsection{Discovery}

Paraspeckles are a recently discovered nuclear body found through a proteomic study of purified human nucleoli [12]. This analysis identified 271 nucleolar proteins, 80 of which were encoded by novel or uncharacterized human genes [12]. Further characterization of non-POU (Pit1/Oct1/UNC-86) domain containing octamer-binding (NONO), paraspeckle protein 1 (PSP1) and paraspeckle protein 2 (PSP2) detected a nuclear compartment located close to, but distinct from, nuclear speckles [78].

\subsubsection{Key Components of the Paraspeckle}

Established paraspeckle component proteins include the aforementioned NONO, PSP1 and PSP2, as well as splicing factor proline/glutamine-rich (SFPQ) [280] and mammalian cleavage factor I 68 (CFIm68) [80]. Additionally, a recent study identified 35 additional paraspeckle proteins, including RNA-binding proteins, additional members of the CFIm complex and several hnRNPs that bind RNA Pol II transcripts [281]. Paraspeckles also contain the long ncRNA nuclear-enriched abundant transcript 1 (NEAT1) [81-83] and nuclear-retained RNA CAT2 transcribed nuclear (Ctn) [79] (Table 1).

\subsubsection{Functions of Key Components}

Paraspeckle proteins participate in several biological processes. PSP1, NONO and SFPQ are members of the Drosophila behavior/human splicing (DBHS) family of RNA-binding proteins that possess two tandem RNA recognition motifs (RRMs). The DBHS family proteins are involved in nuclear processes, such as transcription, pre-mRNA processing and DNA repair [129,282-290]. RNAi-mediated knockdown of either $N O N O$ or $S F P Q$ leads to a loss of paraspeckles [83]. Animal models targeting DBHS homologues have diverse defects, including those of circadian rhythm, chondrogenesis and neural development [129,130,291] (Table 2).

PSP2 mediates transcription and splicing in a promoter-preferential manner [292]. CFIm68, a subunit of the multimeric CFIm complex, facilitates the recognition of pre-mRNA and the recruitment of factors for pre-mRNA 3'-end processing [293], as well as for nuclear export of mRNA [294].

The NEAT1 RNA is a mammal-specific ncRNA that is developmentally regulated. It is widely expressed in adult mouse tissues, but not earlier in development [133]. Studies of NEAT1 knockdown in cultured human cells and of a knockout Neatl mouse show that these RNAs are essential for paraspeckle formation [81-83,133] (Table 2); however, the Neat1 RNA is not needed for mouse viability, health or fertility [133] (Table 2). 
The mouse-specific Slc7a2 gene encodes two isoforms: the nuclear retained Ctn RNA and the protein coding Cat 2 mRNA [79]. The nuclear retention of Ctn RNA is mediated by the post-transcriptional modification of 3' UTR adenosine to inosine (also known as A-to-I editing) and subsequent binding of the modified RNAs to the paraspeckle components, NONO and SFPQ, as well as matrin 3 [79,295]. In contrast to NEAT1 RNA, depletion of Ctn RNA by antisense oligonucleotide (ASO) knockdown has no effect on paraspeckle formation [79] (Table 2).

\subsubsection{Mechanisms of Gene Expression and the Paraspeckle}

The precise biological role of paraspeckles is unknown; however, analysis of the function of the individual components suggests that paraspeckles contribute to transcriptional regulation and RNA processing (Tables 1 and 2). Since several paraspeckle components are involved in transcription and RNA processing, the paraspeckle might contribute to the coupling of these events, such that the cell can streamline consecutive enzymatic reactions [129,282,283,286].

A function particular to paraspeckles is nuclear RNA retention [79,295]. Exemplifying this function is $C t n$ RNA [79]. While nuclear Ctn RNA has the same coding exons as its protein-coding cytoplasmic counterpart, Cat 2 mRNA, Cat 2 mRNA is transcribed from an alternative promoter and utilizes a distal poly(A) site, resulting in a longer 3' UTR [79]. Following stress, Ctn RNA is cleaved at its 3' UTR, exported from the nucleus and translated into the Cat 2 protein [79]. Cat 2 is an amino acid transporter required for the uptake of arginine. Arginine is required for nitric oxide synthesis by the L-arginine-nitric oxide pathway, which is induced by stresses, such as infection and wound healing [296]. Nuclear RNA retention, therefore, provides an accessible pool of ready-to-use transcripts for rapid responses to stimuli. Although only a single mouse-specific RNA is known to be regulated by nuclear RNA retention [79], it is likely that this mechanism also exists in humans, since many human poly(A)+ RNAs are retained in the nucleus [297], and numerous A-to-I edited human RNAs have been identified [298-300].

\subsubsection{Human Diseases Associated with the Paraspeckle}

No human diseases have been described for mutations in genes encoding for paraspeckle proteins or RNAs.

\section{Discussion}

As proposed by Rabl in 1885 [301], interphase chromosomes have a territorial organization and subsequent studies have shown that the DNA from chromosomes is not randomly intertwined, but rather, occupies non-overlapping territories of irregular shape [302-306]. Genes are generally distributed along the periphery of chromosome territories and loop out into interchromosomal domains upon the induction of gene expression [307-317]. Nuclear bodies, such as Cajal bodies and nuclear speckles, and specific nascent RNA accumulations lie in the interchromosomal domains and are excluded from the chromosome territories [318-322]. Given these observations and the finding that the positioning of interphase chromosomes is frequently inherited from mother to daughter nuclei in mammals, the spatial relationship of DNA to nuclear bodies may represent a higher order mechanism 
for regulating gene expression [323-327]. Consistent with such a hypothesis, chromosomal translocations cause large-scale changes in gene expression attributable to the change in the chromosome territory [328]. Aside from differences in interaction with the nuclear matrix, one contributor to this change in gene expression could be the change in the spatial relationship with the nuclear compartments that concentrate and sequester factors required for gene expression or chromatin homeostasis.

Besides potentially regulating gene expression based on concentration or sequestration of factors, nuclear bodies provide a structure for cells to couple and integrate sequential processes in order to increase the efficiency and tuning of gene expression. Although our understanding of this integration is primitive, traces of this integration can be observed in the way in which nuclear bodies share factors and interact with other nuclear bodies and nuclear components in time and space. Many factors are not exclusive to one subnuclear domain and have functions in several domains, e.g., coilin and the SMN complex. This sharing of factors not only allows the cell to maximize the function for any given protein, but also potentially provides a mechanism by which different nuclear bodies can communicate with one another. For instance, the transfer of SMN between the Cajal body and the Gemini of Cajal body might be a mechanism of communication and of modulating their respective functions. Finally, the histone locus body and its role in the transcription of the replication-dependent histone genes and the seamless coordination with the cell cycle exemplify the interaction of a nuclear body with temporal nuclear functions.

Several observations also suggest that this integration extends beyond the modulation of gene expression to that of a fundamental role in global nuclear homeostasis. Many recent studies have uncovered intertwining of the processes of DNA transcription, replication, repair and recombination. Although partially attributable to the common substrate DNA and some proteins functioning in multiple processes, nuclear bodies frequently act as nexi contributing to each or many of these processes [9,10,43,44,69,99,129,196,233,329-335].

As might be predicted for structures mediating responses to stimuli, nuclear bodies are highly dynamic [336,337]. They rapidly assemble or disassemble, as well as change location upon exposure of a cell to various stimuli. Examples of such dynamic responses include the formation of nucleolar caps upon transcription inhibition [338], the formation of nuclear stress bodies in response to cellular stress [40,201], the altered distribution and enlargement of nuclear speckles upon transcription inhibition or heat shock [191,339] and the rapid reassembly of several nuclear bodies following mitosis [337]. Further examples include the increased association between Cajal bodies and Gemini of Cajal bodies, the appearance of paraspeckles and the marked changes in nucleolar positioning, number and association with chromatin territories upon cellular differentiation [131,340,341].

Reinforcing the vital nature of nuclear bodies, they are conserved across species that have been well studied (Table 4). However, very few studies have looked at conservation of the position of nuclear bodies relative to genes across species. One example is the relationship between nucleoli and nucleolar organizer regions (NORs) in nuclei of pachytene spermatocytes from seven mammalian species [342]. NORs consist of tandemly repeated ribosomal genes around which nucleoli form [343,344]. The localization of the nucleoli was largely dependent upon the position of the NOR relative to the chromosome: terminal NORs invariably gave rise to peripheral nucleoli, while intercalated NORs gave rise to central nucleoli [342]. The number of nucleoli was largely dependent on the number of 
nucleolar bivalents: a single nucleolar bivalent gave rise to a single nucleolus, while multiple nucleolar bivalents seeded a variable number of nucleoli [342]. Another comprehensive study of the localization of ribosomal genes in 189 species of animals and plants with diverse karyotypes showed that $90.5 \%$ of NORs were located on a short arm and 85.2\% near the telomere [345,346]. Based on these initial studies, one might hypothesize that nucleoli are non-randomly distributed nuclear bodies with species-specific variation in nuclear architecture. Selection for these interactions would be predicted to have a stabilizing effect on the structure of the genome and the three-dimensional structure of the nucleus. Another nuclear body where position relative to genes might be conserved is the histone locus body. The core replication-dependent histone genes show high conservation across species [347], and it has been demonstrated that histone $\mathrm{H} 2 \mathrm{~B}$ pre-mRNA is sufficient to nucleate histone locus bodies de novo [235]. In agreement with this finding, it has recently been shown that a sequence located between the Drosophila melanogaster histone $\mathrm{H} 3$ and $\mathrm{H} 4$ genes, as well as the transcription of the histone $\mathrm{H} 3$ and $\mathrm{H} 4$ genes facilitate histone locus body formation [128]. Since selection for this interaction would be necessary for the survival of the cell, other species are likely to have a similar mechanism of histone locus body nucleation.

Further work on these intriguing aspects of nuclear bodies will no doubt provide more knowledge regarding the function and regulation of nuclear bodies, as well as their contribution to the regulation of gene expression.

\section{Conclusion}

Nuclear bodies utilize a vast array of gene regulatory mechanisms for efficient and controlled gene expression (Figure 1). Further work to uncover the biological functions, interactions and dynamics of nuclear bodies will give us greater insight into the organizational architecture and three-dimensional landscape of the nucleus and the spatial regulation of gene expression within the nucleus. Although nuclear bodies have profound effects on gene regulation and gene expression, they have been generally underappreciated with respect to their function in health and disease. This emphasizes the need to understand disease in the spatial context of the nucleus.

The study of nuclear bodies and the mechanisms by which they regulate gene expression is an exciting, but complex and challenging area of cell biology. There are likely more nuclear bodies, as well as components and functions of existing nuclear bodies to be discovered and elucidated.

\section{Acknowledgements}

We would like to thank Hok Khim Fam, Kimberly Beirnes, Karen Jiawen Wang and Alireza Baradaran-Heravi and Cristina Dias for critical review of this article. This work was supported in part by grants from the SickKids Foundation-Canadian Institutes of Health Research: Institute of Human Development, Child and Youth Health (C.F.B.), the Michael Smith Foundation for Health Research (CI-SCH-O1899(07-1) to C.F.B.), the National Institute of Diabetes, Digestive and Kidney Diseases, National Institutes of Health (R03 DK062174 and R21DK065725 to C.F.B.), the Association Autour D'Emeric et D'Anthony (C.F.B.) and The Little Giants Foundation (C.F.B.). M.M. was supported by a Four Year Doctoral Fellowship from the University of British Columbia. C.F.B. is a scholar of the Michael Smith Foundation for Health Research and a Clinical Investigator of the Child \& Family Research Institute. 


\section{Conflict of Interest}

The authors declare no conflict of interest.

\section{References and Notes}

1. Venters, B.J.; Pugh, B.F. How eukaryotic genes are transcribed. Crit. Rev. Biochem. Mol. Biol. 2009, 44, 117-141.

2. Hocine, S.; Singer, R.H.; Grunwald, D. RNA processing and export. Cold Spring Harb. Perspect. Biol. 2010, 2, a000752.

3. Gebauer, F.; Hentze, M.W. Molecular mechanisms of translational control. Nat. Rev. Mol. Cell Biol. 2004, 5, 827-835.

4. Carmo-Fonseca, M.; Berciano, M.T.; Lafarga, M. Orphan nuclear bodies. Cold Spring Harb. Perspect. Biol. 2010, 2, a000703.

5. Lallemand-Breitenbach, V.; de The, H. PML nuclear bodies. Cold Spring Harb. Perspect. Biol. 2010, 2, a000661.

6. Wagner, R. Einige bemerkungen und fragen über das keimbläschen (vesicular germinativa). Müller's Arch. Anat. Physiol. Wissenschaftliche Med. 1835, 373-377.

7. Valentin, G. Repertorium für anatomie und physiologie; Verlag von Veit und Comp: Berlin, Germany, 1836; Volume 1, pp. 1-293.

8. Brown, D.D.; Gurdon, J.B. Absence of ribosomal RNA synthesis in the anucleolate mutant of Xenopus laevis. Proc. Natl. Acad. Sci. USA 1964, 51, 139-146.

9. Boisvert, F.M.; van Koningsbruggen, S.; Navascues, J.; Lamond, A.I. The multifunctional nucleolus. Nat. Rev. Mol. Cell Biol. 2007, 8, 574-585.

10. Boulon, S.; Westman, B.J.; Hutten, S.; Boisvert, F.M.; Lamond, A.I. The nucleolus under stress. Mol. Cell 2010, 40, 216-227.

11. Gerbi, S.A.; Borovjagin, A.V.; Lange, T.S. The nucleolus: A site of ribonucleoprotein maturation. Curr. Opin. Cell Biol. 2003, 15, 318-325.

12. Andersen, J.S.; Lyon, C.E.; Fox, A.H.; Leung, A.K.; Lam, Y.W.; Steen, H.; Mann, M.; Lamond, A.I. Directed proteomic analysis of the human nucleolus. Curr. Biol. 2002, 12, 1-11.

13. Scherl, A.; Coute, Y.; Deon, C.; Calle, A.; Kindbeiter, K.; Sanchez, J.C.; Greco, A.; Hochstrasser, D.; Diaz, J.J. Functional proteomic analysis of human nucleolus. Mol. Biol. Cell 2002, 13, 4100-4109.

14. Maggi, L.B., Jr.; Kuchenruether, M.; Dadey, D.Y.; Schwope, R.M.; Grisendi, S.; Townsend, R.R.; Pandolfi, P.P.; Weber, J.D. Nucleophosmin serves as a rate-limiting nuclear export chaperone for the mammalian ribosome. Mol. Cell. Biol. 2008, 28, 7050-7065.

15. Ginisty, H.; Amalric, F.; Bouvet, P. Nucleolin functions in the first step of ribosomal RNA processing. EMBO J. 1998, 17, 1476-1486.

16. Rickards, B.; Flint, S.J.; Cole, M.D.; LeRoy, G. Nucleolin is required for RNA polymerase I transcription in vivo. Mol. Cell. Biol. 2007, 27, 937-948.

17. Kiss, T. Small nucleolar RNA-guided post-transcriptional modification of cellular RNAs. EMBO J. 2001, 20, 3617-3622. 
18. Isaac, C.; Yang, Y.; Meier, U.T. Nopp140 functions as a molecular link between the nucleolus and the coiled bodies. J. Cell Biol. 1998, 142, 319-329.

19. Spector, D.L.; Ochs, R.L.; Busch, H. Silver staining, immunofluorescence, and immunoelectron microscopic localization of nucleolar phosphoproteins B23 and C23. Chromosoma 1984, 90, 139-148.

20. Ochs, R.L.; Lischwe, M.A.; Spohn, W.H.; Busch, H. Fibrillarin: A new protein of the nucleolus identified by autoimmune sera. Biol. Cell 1985, 54, 123-133.

21. Leung, A.K.; Lamond, A.I. In vivo analysis of NHPX reveals a novel nucleolar localization pathway involving a transient accumulation in splicing speckles. J. Cell Biol. 2002, 157, 615-629.

22. Gautier, T.; Berges, T.; Tollervey, D.; Hurt, E. Nucleolar KKE/D repeat proteins Nop56p and Nop58p interact with Nop1p and are required for ribosome biogenesis. Mol. Cell. Biol. 1997, 17, 7088-7098.

23. Heiss, N.S.; Girod, A.; Salowsky, R.; Wiemann, S.; Pepperkok, R.; Poustka, A. Dyskerin localizes to the nucleolus and its mislocalization is unlikely to play a role in the pathogenesis of dyskeratosis congenita. Hum. Mol. Genet. 1999, 8, 2515-2524.

24. Girard, J.P.; Lehtonen, H.; Caizergues-Ferrer, M.; Amalric, F.; Tollervey, D.; Lapeyre, B. GAR1 is an essential small nucleolar RNP protein required for pre-rRNA processing in yeast. EMBO J. 1992, 11, 673-682.

25. Henras, A.; Henry, Y.; Bousquet-Antonelli, C.; Noaillac-Depeyre, J.; Gelugne, J.P.; CaizerguesFerrer, M. Nhp2p and Nop10p are essential for the function of H/ACA snoRNPs. EMBO J. 1998, 17, 7078-7090.

26. Meier, U.T.; Blobel, G. Nopp140 shuttles on tracks between nucleolus and cytoplasm. Cell 1992, 70, 127-138.

27. Scheer, U.; Rose, K.M. Localization of RNA polymerase I in interphase cells and mitotic chromosomes by light and electron microscopic immunocytochemistry. Proc. Natl. Acad. Sci. USA 1984, 81, 1431-1435.

28. Tyc, K.; Steitz, J.A. U3, U8 and U13 comprise a new class of mammalian snRNPs localized in the cell nucleolus. EMBOJ. 1989, 8, 3113-3119.

29. Lange, T.S.; Borovjagin, A.; Maxwell, E.S.; Gerbi, S.A. Conserved boxes C and D are essential nucleolar localization elements of U14 and U8 snoRNAs. EMBO J. 1998, 17, 3176-3187.

30. Selvamurugan, N.; Joost, O.H.; Haas, E.S.; Brown, J.W.; Galvin, N.J.; Eliceiri, G.L. Intracellular localization and unique conserved sequences of three small nucleolar RNAs. Nucleic Acids Res. 1997, 25, 1591-1596.

31. Caceres, J.F.; Misteli, T.; Screaton, G.R.; Spector, D.L.; Krainer, A.R. Role of the modular domains of SR proteins in subnuclear localization and alternative splicing specificity. $J$. Cell Biol. 1997, 138, 225-238.

32. Fu, X.D.; Maniatis, T. Factor required for mammalian spliceosome assembly is localized to discrete regions in the nucleus. Nature 1990, 343, 437-441.

33. Mintz, P.J.; Patterson, S.D.; Neuwald, A.F.; Spahr, C.S.; Spector, D.L. Purification and biochemical characterization of interchromatin granule clusters. EMBO J. 1999, 18, 4308-4320.

34. Saitoh, N.; Spahr, C.S.; Patterson, S.D.; Bubulya, P.; Neuwald, A.F.; Spector, D.L. Proteomic analysis of interchromatin granule clusters. Mol. Biol. Cell 2004, 15, 3876-3890. 
35. Colwill, K.; Pawson, T.; Andrews, B.; Prasad, J.; Manley, J.L.; Bell, J.C.; Duncan, P.I. The $\mathrm{Clk} / \mathrm{Sty}$ protein kinase phosphorylates SR splicing factors and regulates their intranuclear distribution. EMBO J. 1996, 15, 265-275.

36. Bregman, D.B.; Du, L.; van der Zee, S.; Warren, S.L. Transcription-dependent redistribution of the large subunit of RNA polymerase II to discrete nuclear domains. J. Cell Biol. 1995, 129, 287-298.

37. Huang, S.; Spector, D.L. U1 and U2 small nuclear RNAs are present in nuclear speckles. Proc. Natl. Acad. Sci. USA 1992, 89, 305-308.

38. Hutchinson, J.N.; Ensminger, A.W.; Clemson, C.M.; Lynch, C.R.; Lawrence, J.B.; Chess, A. A screen for nuclear transcripts identifies two linked noncoding RNAs associated with SC35 splicing domains. BMC Genomics 2007, 8, 39.

39. Carter, K.C.; Taneja, K.L.; Lawrence, J.B. Discrete nuclear domains of poly(A) RNA and their relationship to the functional organization of the nucleus. J. Cell Biol. 1991, 115, 1191-1202.

40. Sarge, K.D.; Murphy, S.P.; Morimoto, R.I. Activation of heat shock gene transcription by heat shock factor 1 involves oligomerization, acquisition of DNA-binding activity, and nuclear localization and can occur in the absence of stress. Mol. Cell. Biol. 1993, 13, 1392-1407.

41. Alastalo, T.P.; Hellesuo, M.; Sandqvist, A.; Hietakangas, V.; Kallio, M.; Sistonen, L. Formation of nuclear stress granules involves HSF2 and coincides with the nucleolar localization of Hsp70. J. Cell Sci. 2003, 116, 3557-3570.

42. Weighardt, F.; Cobianchi, F.; Cartegni, L.; Chiodi, I.; Villa, A.; Riva, S.; Biamonti, G. A novel hnRNP protein (HAP/SAF-B) enters a subset of hnRNP complexes and relocates in nuclear granules in response to heat shock. J. Cell Sci. 1999, 112, 1465-1476.

43. Denegri, M.; Chiodi, I.; Corioni, M.; Cobianchi, F.; Riva, S.; Biamonti, G. Stress-induced nuclear bodies are sites of accumulation of pre-mRNA processing factors. Mol. Biol. Cell 2001, $12,3502-3514$.

44. Jolly, C.; Metz, A.; Govin, J.; Vigneron, M.; Turner, B.M.; Khochbin, S.; Vourc'h, C. Stressinduced transcription of satellite III repeats. J. Cell Biol. 2004, 164, 25-33.

45. Jackson, D.A.; Iborra, F.J.; Manders, E.M.; Cook, P.R. Numbers and organization of RNA polymerases, nascent transcripts, and transcription units in HeLa nuclei. Mol. Biol. Cell 1998, 9 , 1523-1536.

46. Melnik, S.; Deng, B.; Papantonis, A.; Baboo, S.; Carr, I.M.; Cook, P.R. The proteomes of transcription factories containing RNA polymerases I, II or III. Nat. Methods 2011, 8, 963-968.

47. Raska, I.; Andrade, L.E.; Ochs, R.L.; Chan, E.K.; Chang, C.M.; Roos, G.; Tan, E.M. Immunological and ultrastructural studies of the nuclear coiled body with autoimmune antibodies. Exp. Cell Res. 1991, 195, 27-37.

48. Andrade, L.E.; Chan, E.K.; Raska, I.; Peebles, C.L.; Roos, G.; Tan, E.M. Human autoantibody to a novel protein of the nuclear coiled body: Immunological characterization and cDNA cloning of p80-coilin. J. Exp. Med. 1991, 173, 1407-1419.

49. Raska, I.; Ochs, R.L.; Andrade, L.E.; Chan, E.K.; Burlingame, R.; Peebles, C.; Gruol, D.; Tan, E.M. Association between the nucleolus and the coiled body. J. Struct. Biol. 1990, 104, 120-127. 
50. Verheggen, C.; Lafontaine, D.L.; Samarsky, D.; Mouaikel, J.; Blanchard, J.M.; Bordonne, R.; Bertrand, E. Mammalian and yeast U3 snoRNPs are matured in specific and related nuclear compartments. EMBO J. 2002, 21, 2736-2745.

51. Meier, U.T.; Blobel, G. NAP57, a mammalian nucleolar protein with a putative homolog in yeast and bacteria. J. Cell Biol. 1994, 127, 1505-1514.

52. Pogacic, V.; Dragon, F.; Filipowicz, W. Human H/ACA small nucleolar RNPs and telomerase share evolutionarily conserved proteins NHP2 and NOP10. Mol. Cell. Biol. 2000, 20, 9028-9040.

53. Zhu, Y.; Tomlinson, R.L.; Lukowiak, A.A.; Terns, R.M.; Terns, M.P. Telomerase RNA accumulates in Cajal bodies in human cancer cells. Mol. Biol. Cell 2004, 15, 81-90.

54. Venteicher, A.S.; Abreu, E.B.; Meng, Z.; McCann, K.E.; Terns, R.M.; Veenstra, T.D.; Terns, M.P.; Artandi, S.E. A human telomerase holoenzyme protein required for Cajal body localization and telomere synthesis. Science 2009, 323, 644-648.

55. Carvalho, T.; Almeida, F.; Calapez, A.; Lafarga, M.; Berciano, M.T.; Carmo-Fonseca, M. The spinal muscular atrophy disease gene product, SMN: A link between snRNP biogenesis and the Cajal (coiled) body. J. Cell Biol. 1999, 147, 715-728.

56. Darzacq, X.; Jady, B.E.; Verheggen, C.; Kiss, A.M.; Bertrand, E.; Kiss, T. Cajal body-specific small nuclear RNAs: A novel class of 2'-O-methylation and pseudouridylation guide RNAs. EMBO J. 2002, 21, 2746-2756.

57. Carmo-Fonseca, M.; Pepperkok, R.; Carvalho, M.T.; Lamond, A.I. Transcription-dependent colocalization of the U1, U2, U4/U6, and U5 snRNPs in coiled bodies. J. Cell Biol. 1992, $117,1-14$.

58. Matera, A.G.; Ward, D.C. Nucleoplasmic organization of small nuclear ribonucleoproteins in cultured human cells. J. Cell Biol. 1993, 121, 715-727.

59. Narayanan, A.; Speckmann, W.; Terns, R.; Terns, M.P. Role of the box C/D motif in localization of small nucleolar RNAs to coiled bodies and nucleoli. Mol. Biol. Cell 1999, 10, 2131-2147.

60. Liu, Q.; Dreyfuss, G. A novel nuclear structure containing the survival of motor neurons protein. EMBO J. 1996, 15, 3555-3565.

61. Liu, Q.; Fischer, U.; Wang, F.; Dreyfuss, G. The spinal muscular atrophy disease gene product, SMN, and its associated protein SIP1 are in a complex with spliceosomal snRNP proteins. Cell 1997, 90, 1013-1021.

62. Charroux, B.; Pellizzoni, L.; Perkinson, R.A.; Shevchenko, A.; Mann, M.; Dreyfuss, G. Gemin3: A novel DEAD box protein that interacts with SMN, the spinal muscular atrophy gene product, and is a component of gems. J. Cell Biol. 1999, 147, 1181-1194.

63. Charroux, B.; Pellizzoni, L.; Perkinson, R.A.; Yong, J.; Shevchenko, A.; Mann, M.; Dreyfuss, G. Gemin4: A novel component of the SMN complex that is found in both gems and nucleoli. $J$. Cell Biol. 2000, 148, 1177-1186.

64. Gubitz, A.K.; Mourelatos, Z.; Abel, L.; Rappsilber, J.; Mann, M.; Dreyfuss, G. Gemin5, a novel WD repeat protein component of the SMN complex that binds Sm proteins. J. Biol. Chem. 2002, 277, 5631-5636.

65. Pellizzoni, L.; Baccon, J.; Rappsilber, J.; Mann, M.; Dreyfuss, G. Purification of native survival of motor neurons complexes and identification of Gemin6 as a novel component. J. Biol. Chem. 2002, 277, 7540-7545. 
66. Baccon, J.; Pellizzoni, L.; Rappsilber, J.; Mann, M.; Dreyfuss, G. Identification and characterization of Gemin7, a novel component of the survival of motor neuron complex. J. Biol. Chem. 2002, 277, 31957-31962.

67. Carissimi, C.; Saieva, L.; Baccon, J.; Chiarella, P.; Maiolica, A.; Sawyer, A.; Rappsilber, J.; Pellizzoni, L. Gemin8 is a novel component of the survival motor neuron complex and functions in small nuclear ribonucleoprotein assembly. J. Biol. Chem. 2006, 281, 8126-8134.

68. Gangwani, L.; Mikrut, M.; Theroux, S.; Sharma, M.; Davis, R.J. Spinal muscular atrophy disrupts the interaction of ZPR1 with the SMN protein. Nat. Cell Biol. 2001, 3, 376-383.

69. Ma, T.; Van Tine, B.A.; Wei, Y.; Garrett, M.D.; Nelson, D.; Adams, P.D.; Wang, J.; Qin, J.; Chow, L.T.; Harper, J.W. Cell cycle-regulated phosphorylation of p220(NPAT) by cyclin E/Cdk2 in Cajal bodies promotes histone gene transcription. Genes Dev. 2000, 14, 2298-2313.

70. Ghule, P.N.; Dominski, Z.; Yang, X.C.; Marzluff, W.F.; Becker, K.A.; Harper, J.W.; Lian, J.B.; Stein, J.L.; van Wijnen, A.J.; Stein, G.S. Staged assembly of histone gene expression machinery at subnuclear foci in the abbreviated cell cycle of human embryonic stem cells. Proc. Natl. Acad. Sci. USA 2008, 105, 16964-16969.

71. Liu, J.L.; Murphy, C.; Buszczak, M.; Clatterbuck, S.; Goodman, R.; Gall, J.G. The Drosophila melanogaster Cajal body. J. Cell Biol. 2006, 172, 875-884.

72. Barcaroli, D.; Dinsdale, D.; Neale, M.H.; Bongiorno-Borbone, L.; Ranalli, M.; Munarriz, E.; Sayan, A.E.; McWilliam, J.M.; Smith, T.M.; Fava, E.; et al. FLASH is an essential component of Cajal bodies. Proc. Natl. Acad. Sci. USA 2006, 103, 14802-14807.

73. Narita, T.; Yung, T.M.; Yamamoto, J.; Tsuboi, Y.; Tanabe, H.; Tanaka, K.; Yamaguchi, Y.; Handa, H. NELF interacts with CBC and participates in $3^{\prime}$ end processing of replicationdependent histone mRNAs. Mol. Cell 2007, 26, 349-365.

74. Miele, A.; Braastad, C.D.; Holmes, W.F.; Mitra, P.; Medina, R.; Xie, R.; Zaidi, S.K.; Ye, X.; Wei, Y.; Harper, J.W.; et al. HiNF-P directly links the cyclin E/CDK2/p220NPAT pathway to histone $\mathrm{H} 4$ gene regulation at the G1/S phase cell cycle transition. Mol. Cell. Biol. 2005, 25, 6140-6153.

75. Gangwani, L. Deficiency of the zinc finger protein ZPR1 causes defects in transcription and cell cycle progression. J. Biol. Chem. 2006, 281, 40330-40340.

76. Liu, J.L.; Wu, Z.; Nizami, Z.; Deryusheva, S.; Rajendra, T.K.; Beumer, K.J.; Gao, H.; Matera, A.G.; Carroll, D.; Gall, J.G. Coilin is essential for Cajal body organization in Drosophila melanogaster. Mol. Biol. Cell 2009, 20, 1661-1670.

77. Frey, M.R.; Matera, A.G. Coiled bodies contain U7 small nuclear RNA and associate with specific DNA sequences in interphase human cells. Proc. Natl. Acad. Sci. USA 1995, 92, 5915-5919.

78. Fox, A.H.; Lam, Y.W.; Leung, A.K.; Lyon, C.E.; Andersen, J.; Mann, M.; Lamond, A.I. Paraspeckles: A novel nuclear domain. Curr. Biol. 2002, 12, 13-25.

79. Prasanth, K.V.; Prasanth, S.G.; Xuan, Z.; Hearn, S.; Freier, S.M.; Bennett, C.F.; Zhang, M.Q.; Spector, D.L. Regulating gene expression through RNA nuclear retention. Cell 2005, 123, 249-263.

80. Dettwiler, S.; Aringhieri, C.; Cardinale, S.; Keller, W.; Barabino, S.M. Distinct sequence motifs within the $68-\mathrm{kDa}$ subunit of cleavage factor Im mediate RNA binding, protein-protein interactions, and subcellular localization. J. Biol. Chem. 2004, 279, 35788-35797. 
81. Clemson, C.M.; Hutchinson, J.N.; Sara, S.A.; Ensminger, A.W.; Fox, A.H.; Chess, A.; Lawrence, J.B. An architectural role for a nuclear noncoding RNA: NEAT1 RNA is essential for the structure of paraspeckles. Mol. Cell 2009, 33, 717-726.

82. Sunwoo, H.; Dinger, M.E.; Wilusz, J.E.; Amaral, P.P.; Mattick, J.S.; Spector, D.L. MEN epsilon/beta nuclear-retained non-coding RNAs are up-regulated upon muscle differentiation and are essential components of paraspeckles. Genome Res. 2009, 19, 347-359.

83. Sasaki, Y.T.; Ideue, T.; Sano, M.; Mituyama, T.; Hirose, T. MENepsilon/beta noncoding RNAs are essential for structural integrity of nuclear paraspeckles. Proc. Natl. Acad. Sci. USA 2009, $106,2525-2530$.

84. Tollervey, D.; Lehtonen, H.; Carmo-Fonseca, M.; Hurt, E.C. The small nucleolar RNP protein NOP1 (fibrillarin) is required for pre-rRNA processing in yeast. EMBO J. 1991, 10, 573-583.

85. Jack, K.; Bellodi, C.; Landry, D.M.; Niederer, R.O.; Meskauskas, A.; Musalgaonkar, S.; Kopmar, N.; Krasnykh, O.; Dean, A.M.; Thompson, S.R.; et al. rRNA pseudouridylation defects affect ribosomal ligand binding and translational fidelity from yeast to human cells. Mol. Cell 2011, 44, 660-666.

86. Haaf, T.; Ward, D.C. Inhibition of RNA polymerase II transcription causes chromatin decondensation, loss of nucleolar structure, and dispersion of chromosomal domains. Exp. Cell Res. 1996, 224, 163-173.

87. Flygare, J.; Aspesi, A.; Bailey, J.C.; Miyake, K.; Caffrey, J.M.; Karlsson, S.; Ellis, S.R. Human RPS19, the gene mutated in Diamond-Blackfan anemia, encodes a ribosomal protein required for the maturation of 40S ribosomal subunits. Blood 2007, 109, 980-986.

88. Hughes, J.M.; Ares, M., Jr. Depletion of U3 small nucleolar RNA inhibits cleavage in the 5' external transcribed spacer of yeast pre-ribosomal RNA and impairs formation of $18 \mathrm{~S}$ ribosomal RNA. EMBO J. 1991, 10, 4231-4239.

89. Tripathi, V.; Song, D.Y.; Zong, X.; Shevtsov, S.P.; Hearn, S.; Fu, X.D.; Dundr, M.; Prasanth, K.V. SRSF1 regulates the assembly of pre-mRNA processing factors in nuclear speckles. Mol. Biol. Cell 2012, 23, 3694-3706.

90. Sacco-Bubulya, P.; Spector, D.L. Disassembly of interchromatin granule clusters alters the coordination of transcription and pre-mRNA splicing. J. Cell Biol. 2002, 156, 425-436.

91. Tripathi, V.; Ellis, J.D.; Shen, Z.; Song, D.Y.; Pan, Q.; Watt, A.T.; Freier, S.M.; Bennett, C.F.; Sharma, A.; Bubulya, P.A.; et al. The nuclear-retained noncoding RNA MALAT1 regulates alternative splicing by modulating SR splicing factor phosphorylation. Mol. Cell 2010, 39, 925-938.

92. Sharma, A.; Takata, H.; Shibahara, K.; Bubulya, A.; Bubulya, P.A. Son is essential for nuclear speckle organization and cell cycle progression. Mol. Biol. Cell 2010, 21, 650-663.

93. Okada, M.; Jang, S.W.; Ye, K. Akt phosphorylation and nuclear phosphoinositide association mediate mRNA export and cell proliferation activities by ALY. Proc. Natl. Acad. Sci. USA 2008, 105, 8649-8654.

94. Dias, A.P.; Dufu, K.; Lei, H.; Reed, R. A role for TREX components in the release of spliced mRNA from nuclear speckle domains. Nat. Commun. 2010, 1, 97.

95. Nakagawa, S.; Ip, J.Y.; Shioi, G.; Tripathi, V.; Zong, X.; Hirose, T.; Prasanth, K.V. Malat1 is not an essential component of nuclear speckles in mice. RNA 2012, 18, 1487-1499. 
96. Eissmann, M.; Gutschner, T.; Hammerle, M.; Gunther, S.; Caudron-Herger, M.; Gross, M.; Schirmacher, P.; Rippe, K.; Braun, T.; Zornig, M.; et al. Loss of the abundant nuclear non-coding RNA MALAT1 is compatible with life and development. RNA Biol. 2012, 9, 1076-1087.

97. O'Keefe, R.T.; Mayeda, A.; Sadowski, C.L.; Krainer, A.R.; Spector, D.L. Disruption of pre-mRNA splicing in vivo results in reorganization of splicing factors. J. Cell Biol. 1994, 124, 249-260.

98. Sandqvist, A.; Bjork, J.K.; Akerfelt, M.; Chitikova, Z.; Grichine, A.; Vourc'h, C.; Jolly, C.; Salminen, T.A.; Nymalm, Y.; Sistonen, L. Heterotrimerization of heat-shock factors 1 and 2 provides a transcriptional switch in response to distinct stimuli. Mol. Biol. Cell 2009, 20, 1340-1347.

99. Jackson, D.A.; Hassan, A.B.; Errington, R.J.; Cook, P.R. Visualization of focal sites of transcription within human nuclei. EMBO J. 1993, 12, 1059-1065.

100. Pombo, A.; Jackson, D.A.; Hollinshead, M.; Wang, Z.; Roeder, R.G.; Cook, P.R. Regional specialization in human nuclei: Visualization of discrete sites of transcription by RNA polymerase III. EMBO J. 1999, 18, 2241-2253.

101. Tucker, K.E.; Berciano, M.T.; Jacobs, E.Y.; LePage, D.F.; Shpargel, K.B.; Rossire, J.J.; Chan, E.K.; Lafarga, M.; Conlon, R.A.; Matera, A.G. Residual Cajal bodies in coilin knockout mice fail to recruit Sm snRNPs and SMN, the spinal muscular atrophy gene product. J. Cell Biol. 2001, 154, 293-307.

102. Walker, M.P.; Tian, L.; Matera, A.G. Reduced viability, fertility and fecundity in mice lacking the cajal body marker protein, coilin. PLoS One 2009, 4, e6171.

103. Bauer, D.W.; Gall, J.G. Coiled bodies without coilin. Mol. Biol. Cell 1997, 8, 73-82.

104. Deryusheva, S.; Gall, J.G. Small Cajal body-specific RNAs of Drosophila function in the absence of Cajal bodies. Mol. Biol. Cell 2009, 20, 5250-5259.

105. Batista, L.F.; Pech, M.F.; Zhong, F.L.; Nguyen, H.N.; Xie, K.T.; Zaug, A.J.; Crary, S.M.; Choi, J.; Sebastiano, V.; Cherry, A.; et al. Telomere shortening and loss of self-renewal in dyskeratosis congenita induced pluripotent stem cells. Nature 2011, 474, 399-402.

106. Renvoise, B.; Colasse, S.; Burlet, P.; Viollet, L.; Meier, U.T.; Lefebvre, S. The loss of the snoRNP chaperone Nopp140 from Cajal bodies of patient fibroblasts correlates with the severity of spinal muscular atrophy. Hum. Mol. Genet. 2009, 18, 1181-1189.

107. Lefebvre, S.; Burlet, P.; Liu, Q.; Bertrandy, S.; Clermont, O.; Munnich, A.; Dreyfuss, G.; Melki, J. Correlation between severity and SMN protein level in spinal muscular atrophy. Nat. Genet. 1997, 16, 265-269.

108. Coovert, D.D.; Le, T.T.; McAndrew, P.E.; Strasswimmer, J.; Crawford, T.O.; Mendell, J.R.; Coulson, S.E.; Androphy, E.J.; Prior, T.W.; Burghes, A.H. The survival motor neuron protein in spinal muscular atrophy. Hum. Mol. Genet. 1997, 6, 1205-1214.

109. Girard, C.; Neel, H.; Bertrand, E.; Bordonne, R. Depletion of SMN by RNA interference in HeLa cells induces defects in Cajal body formation. Nucleic Acids Res. 2006, 34, 2925-2932.

110. Feng, W.; Gubitz, A.K.; Wan, L.; Battle, D.J.; Dostie, J.; Golembe, T.J.; Dreyfuss, G. Gemins modulate the expression and activity of the SMN complex. Hum. Mol. Genet. 2005, 14, 1605-1611.

111. Shpargel, K.B.; Matera, A.G. Gemin proteins are required for efficient assembly of Sm-class ribonucleoproteins. Proc. Natl. Acad. Sci. USA 2005, 102, 17372-17377. 
112. Frugier, T.; Tiziano, F.D.; Cifuentes-Diaz, C.; Miniou, P.; Roblot, N.; Dierich, A.; Le Meur, M.; Melki, J. Nuclear targeting defect of SMN lacking the C-terminus in a mouse model of spinal muscular atrophy. Hum. Mol. Genet. 2000, 9, 849-858.

113. Gabanella, F.; Butchbach, M.E.; Saieva, L.; Carissimi, C.; Burghes, A.H.; Pellizzoni, L. Ribonucleoprotein assembly defects correlate with spinal muscular atrophy severity and preferentially affect a subset of spliceosomal snRNPs. PLoS One 2007, 2, e921.

114. Zhang, Z.; Lotti, F.; Dittmar, K.; Younis, I.; Wan, L.; Kasim, M.; Dreyfuss, G. SMN deficiency causes tissue-specific perturbations in the repertoire of snRNAs and widespread defects in splicing. Cell 2008, 133, 585-600.

115. Campion, Y.; Neel, H.; Gostan, T.; Soret, J.; Bordonne, R. Specific splicing defects in S. pombe carrying a degron allele of the Survival of Motor Neuron gene. EMBO J. 2010, 29, 1817-1829.

116. Shpargel, K.B.; Praveen, K.; Rajendra, T.K.; Matera, A.G. Gemin3 is an essential gene required for larval motor function and pupation in Drosophila. Mol. Biol. Cell 2009, 20, 90-101.

117. Gangwani, L.; Flavell, R.A.; Davis, R.J. ZPR1 is essential for survival and is required for localization of the survival motor neurons (SMN) protein to Cajal bodies. Mol. Cell. Biol. 2005, $25,2744-2756$.

118. Doran, B.; Gherbesi, N.; Hendricks, G.; Flavell, R.A.; Davis, R.J.; Gangwani, L. Deficiency of the zinc finger protein ZPR1 causes neurodegeneration. Proc. Natl. Acad. Sci. USA 2006, 103, 7471-7475.

119. Di Fruscio, M.; Weiher, H.; Vanderhyden, B.C.; Imai, T.; Shiomi, T.; Hori, T.A.; Jaenisch, R.; Gray, D.A. Proviral inactivation of the Npat gene of Mpv 20 mice results in early embryonic arrest. Mol. Cell. Biol. 1997, 17, 4080-4086.

120. Sullivan, K.D.; Mullen, T.E.; Marzluff, W.F.; Wagner, E.J. Knockdown of SLBP results in nuclear retention of histone mRNA. RNA 2009, 15, 459-472.

121. Sullivan, E.; Santiago, C.; Parker, E.D.; Dominski, Z.; Yang, X.; Lanzotti, D.J.; Ingledue, T.C.; Marzluff, W.F.; Duronio, R.J. Drosophila stem loop binding protein coordinates accumulation of mature histone mRNA with cell cycle progression. Genes Dev. 2001, 15, 173-187.

122. White, A.E.; Leslie, M.E.; Calvi, B.R.; Marzluff, W.F.; Duronio, R.J. Developmental and cell cycle regulation of the Drosophila histone locus body. Mol. Biol. Cell 2007, 18, 2491-2502.

123. Godfrey, A.C.; White, A.E.; Tatomer, D.C.; Marzluff, W.F.; Duronio, R.J. The Drosophila U7 snRNP proteins Lsm10 and Lsm11 are required for histone pre-mRNA processing and play an essential role in development. RNA 2009, 15, 1661-1672.

124. Barcaroli, D.; Bongiorno-Borbone, L.; Terrinoni, A.; Hofmann, T.G.; Rossi, M.; Knight, R.A.; Matera, A.G.; Melino, G.; De Laurenzi, V. FLASH is required for histone transcription and Sphase progression. Proc. Natl. Acad. Sci. USA 2006, 103, 14808-14812.

125. De Cola, A.; Bongiorno-Borbone, L.; Bianchi, E.; Barcaroli, D.; Carletti, E.; Knight, R.A.; Di Ilio, C.; Melino, G.; Sette, C.; De Laurenzi, V. FLASH is essential during early embryogenesis and cooperates with p73 to regulate histone gene transcription. Oncogene 2012, 31, 573-582.

126. Xie, R.; Medina, R.; Zhang, Y.; Hussain, S.; Colby, J.; Ghule, P.; Sundararajan, S.; Keeler, M.; Liu, L.J.; van der Deen, M.; et al. The histone gene activator HINFP is a nonredundant cyclin E/CDK2 effector during early embryonic cell cycles. Proc. Natl. Acad. Sci. USA 2009, 106, 12359-12364. 
127. Godfrey, A.C.; Kupsco, J.M.; Burch, B.D.; Zimmerman, R.M.; Dominski, Z.; Marzluff, W.F.; Duronio, R.J. U7 snRNA mutations in Drosophila block histone pre-mRNA processing and disrupt oogenesis. RNA 2006, 12, 396-409.

128. Salzler, H.R.; Tatomer, D.C.; Malek, P.Y.; McDaniel, S.L.; Orlando, A.N.; Marzluff, W.F.; Duronio, R.J. A Sequence in the Drosophila H3-H4 Promoter Triggers Histone Locus Body Assembly and Biosynthesis of Replication-Coupled Histone mRNAs. Dev. Cell 2013, 24, 623-634.

129. Hata, K.; Nishimura, R.; Muramatsu, S.; Matsuda, A.; Matsubara, T.; Amano, K.; Ikeda, F.; Harley, V.R.; Yoneda, T. Paraspeckle protein p54nrb links Sox9-mediated transcription with RNA processing during chondrogenesis in mice. J. Clin. Invest. 2008, 118, 3098-3108.

130. Brown, S.A.; Ripperger, J.; Kadener, S.; Fleury-Olela, F.; Vilbois, F.; Rosbash, M.; Schibler, U. PERIOD1-associated proteins modulate the negative limb of the mammalian circadian oscillator. Science 2005, 308, 693-696.

131. Chen, L.L.; Carmichael, G.G. Altered nuclear retention of mRNAs containing inverted repeats in human embryonic stem cells: Functional role of a nuclear noncoding RNA. Mol. Cell 2009, 35, $467-478$.

132. Kowalska, E.; Ripperger, J.A.; Muheim, C.; Maier, B.; Kurihara, Y.; Fox, A.H.; Kramer, A.; Brown, S.A. Distinct roles of DBHS family members in the circadian transcriptional feedback loop. Mol. Cell. Biol. 2012, 32, 4585-4594.

133. Nakagawa, S.; Naganuma, T.; Shioi, G.; Hirose, T. Paraspeckles are subpopulation-specific nuclear bodies that are not essential in mice. J. Cell Biol. 2011, 193, 31-39.

134. Murano, K.; Okuwaki, M.; Hisaoka, M.; Nagata, K. Transcription regulation of the rRNA gene by a multifunctional nucleolar protein, B23/nucleophosmin, through its histone chaperone activity. Mol. Cell. Biol. 2008, 28, 3114-3126.

135. Cong, R.; Das, S.; Ugrinova, I.; Kumar, S.; Mongelard, F.; Wong, J.; Bouvet, P. Interaction of nucleolin with ribosomal RNA genes and its role in RNA polymerase I transcription. Nucleic Acids Res. 2012, 40, 9441-9454.

136. Lessard, F.; Stefanovsky, V.; Tremblay, M.G.; Moss, T. The cellular abundance of the essential transcription termination factor TTF-I regulates ribosome biogenesis and is determined by MDM2 ubiquitinylation. Nucleic Acids Res. 2012, 40, 5357-5367.

137. Boyd, M.T.; Vlatkovic, N.; Rubbi, C.P. The nucleolus directly regulates p53 export and degradation. J. Cell Biol. 2011, 194, 689-703.

138. Richardson, L.A.; Reed, B.J.; Charette, J.M.; Freed, E.F.; Fredrickson, E.K.; Locke, M.N.; Baserga, S.J.; Gardner, R.G. A conserved deubiquitinating enzyme controls cell growth by regulating RNA polymerase I stability. Cell Rep. 2012, 2, 372-385.

139. Westman, B.J.; Verheggen, C.; Hutten, S.; Lam, Y.W.; Bertrand, E.; Lamond, A.I. A proteomic screen for nucleolar SUMO targets shows SUMOylation modulates the function of Nop5/Nop58. Mol. Cell 2010, 39, 618-631.

140. Haindl, M.; Harasim, T.; Eick, D.; Muller, S. The nucleolar SUMO-specific protease SENP3 reverses SUMO modification of nucleophosmin and is required for rRNA processing. EMBO Rep. 2008, 9, 273-279.

141. Bernardi, R.; Scaglioni, P.P.; Bergmann, S.; Horn, H.F.; Vousden, K.H.; Pandolfi, P.P. PML regulates p53 stability by sequestering Mdm2 to the nucleolus. Nat. Cell Biol. 2004, 6, 665-672. 
142. Mekhail, K.; Gunaratnam, L.; Bonicalzi, M.E.; Lee, S. HIF activation by pH-dependent nucleolar sequestration of VHL. Nat. Cell Biol. 2004, 6, 642-647.

143. Fatyol, K.; Szalay, A.A. The p14ARF tumor suppressor protein facilitates nucleolar sequestration of hypoxia-inducible factor-1alpha (HIF-1alpha ) and inhibits HIF-1-mediated transcription. J. Biol. Chem. 2001, 276, 28421-28429.

144. Lin, D.Y.; Shih, H.M. Essential role of the $58-\mathrm{kDa}$ microspherule protein in the modulation of Daxx-dependent transcriptional repression as revealed by nucleolar sequestration. J. Biol. Chem. 2002, 277, 25446-25456.

145. Bywater, M.J.; Pearson, R.B.; McArthur, G.A.; Hannan, R.D. Dysregulation of the basal RNA polymerase transcription apparatus in cancer. Nat. Rev. Cancer 2013, 13, 299-314.

146. The Treacher Collins Syndrome Collaborative Group. Positional cloning of a gene involved in the pathogenesis of Treacher Collins syndrome. Nat. Genet. 1996, 12, 130-136.

147. Dauwerse, J.G.; Dixon, J.; Seland, S.; Ruivenkamp, C.A.; van Haeringen, A.; Hoefsloot, L.H.; Peters, D.J.; Boers, A.C.; Daumer-Haas, C.; Maiwald, R.; et al. Mutations in genes encoding subunits of RNA polymerases I and III cause Treacher Collins syndrome. Nat. Genet. 2011, $43,20-22$.

148. Draptchinskaia, N.; Gustavsson, P.; Andersson, B.; Pettersson, M.; Willig, T.N.; Dianzani, I.; Ball, S.; Tchernia, G.; Klar, J.; Matsson, H.; et al. The gene encoding ribosomal protein S19 is mutated in Diamond-Blackfan anaemia. Nat. Genet. 1999, 21, 169-175.

149. Gazda, H.T.; Grabowska, A.; Merida-Long, L.B.; Latawiec, E.; Schneider, H.E.; Lipton, J.M.; Vlachos, A.; Atsidaftos, E.; Ball, S.E.; Orfali, K.A.; et al. Ribosomal protein S24 gene is mutated in Diamond-Blackfan anemia. Am. J. Hum. Genet. 2006, 79, 1110-1118.

150. Cmejla, R.; Cmejlova, J.; Handrkova, H.; Petrak, J.; Pospisilova, D. Ribosomal protein S17 gene (RPS17) is mutated in Diamond-Blackfan anemia. Hum. Mutat. 2007, 28, 1178-1182.

151. Farrar, J.E.; Nater, M.; Caywood, E.; McDevitt, M.A.; Kowalski, J.; Takemoto, C.M.; Talbot, C.C., Jr.; Meltzer, P.; Esposito, D.; Beggs, A.H.; et al. Abnormalities of the large ribosomal subunit protein, Rpl35a, in Diamond-Blackfan anemia. Blood 2008, 112, 1582-1592.

152. Gazda, H.T.; Sheen, M.R.; Vlachos, A.; Choesmel, V.; O'Donohue, M.F.; Schneider, H.; Darras, N.; Hasman, C.; Sieff, C.A.; Newburger, P.E.; et al. Ribosomal protein L5 and L11 mutations are associated with cleft palate and abnormal thumbs in Diamond-Blackfan anemia patients. Am. J. Hum. Genet. 2008, 83, 769-780.

153. Doherty, L.; Sheen, M.R.; Vlachos, A.; Choesmel, V.; O'Donohue, M.F.; Clinton, C.; Schneider, H.E.; Sieff, C.A.; Newburger, P.E.; Ball, S.E.; et al. Ribosomal protein genes RPS10 and RPS26 are commonly mutated in Diamond-Blackfan anemia. Am. J. Hum. Genet. 2010, 86, 222-228.

154. Gazda, H.T.; Preti, M.; Sheen, M.R.; O'Donohue, M.F.; Vlachos, A.; Davies, S.M.; Kattamis, A.; Doherty, L.; Landowski, M.; Buros, C.; et al. Frameshift mutation in p53 regulator RPL26 is associated with multiple physical abnormalities and a specific pre-ribosomal RNA processing defect in diamond-blackfan anemia. Hum. Mutat. 2012, 33, 1037-1044.

155. Yu, C.E.; Oshima, J.; Fu, Y.H.; Wijsman, E.M.; Hisama, F.; Alisch, R.; Matthews, S.; Nakura, J.; Miki, T.; Ouais, S.; et al. Positional cloning of the Werner's syndrome gene. Science 1996, $272,258-262$. 
156. Ellis, N.A.; Groden, J.; Ye, T.Z.; Straughen, J.; Lennon, D.J.; Ciocci, S.; Proytcheva, M.; German, J. The Bloom's syndrome gene product is homologous to RecQ helicases. Cell 1995, $83,655-666$.

157. Chakarova, C.F.; Hims, M.M.; Bolz, H.; Abu-Safieh, L.; Patel, R.J.; Papaioannou, M.G.; Inglehearn, C.F.; Keen, T.J.; Willis, C.; Moore, A.T.; et al. Mutations in HPRP3, a third member of pre-mRNA splicing factor genes, implicated in autosomal dominant retinitis pigmentosa. Hum. Mol. Genet. 2002, 11, 87-92.

158. Tanackovic, G.; Ransijn, A.; Ayuso, C.; Harper, S.; Berson, E.L.; Rivolta, C. A missense mutation in PRPF6 causes impairment of pre-mRNA splicing and autosomal-dominant retinitis pigmentosa. Am. J. Hum. Genet. 2011, 88, 643-649.

159. McKie, A.B.; McHale, J.C.; Keen, T.J.; Tarttelin, E.E.; Goliath, R.; van Lith-Verhoeven, J.J.; Greenberg, J.; Ramesar, R.S.; Hoyng, C.B.; Cremers, F.P.; et al. Mutations in the pre-mRNA splicing factor gene PRPC8 in autosomal dominant retinitis pigmentosa (RP13). Hum. Mol. Genet. 2001, 10, 1555-1562.

160. Zhao, C.; Bellur, D.L.; Lu, S.; Zhao, F.; Grassi, M.A.; Bowne, S.J.; Sullivan, L.S.; Daiger, S.P.; Chen, L.J.; Pang, C.P.; et al. Autosomal-dominant retinitis pigmentosa caused by a mutation in SNRNP200, a gene required for unwinding of U4/U6 snRNAs. Am. J. Hum. Genet. 2009, $85,617-627$.

161. Lines, M.A.; Huang, L.; Schwartzentruber, J.; Douglas, S.L.; Lynch, D.C.; Beaulieu, C.; GuionAlmeida, M.L.; Zechi-Ceide, R.M.; Gener, B.; Gillessen-Kaesbach, G.; et al. Haploinsufficiency of a spliceosomal GTPase encoded by EFTUD2 causes mandibulofacial dysostosis with microcephaly. Am. J. Hum. Genet. 2012, 90, 369-377.

162. Albers, C.A.; Paul, D.S.; Schulze, H.; Freson, K.; Stephens, J.C.; Smethurst, P.A.; Jolley, J.D.; Cvejic, A.; Kostadima, M.; Bertone, P.; et al. Compound inheritance of a low-frequency regulatory SNP and a rare null mutation in exon-junction complex subunit RBM8A causes TAR syndrome. Nat. Genet. 2012, 44, 435-439, S431-S432.

163. Bernard, G.; Chouery, E.; Putorti, M.L.; Tetreault, M.; Takanohashi, A.; Carosso, G.; Clement, I.; Boespflug-Tanguy, O.; Rodriguez, D.; Delague, V.; et al. Mutations of POLR3A encoding a catalytic subunit of RNA polymerase Pol III cause a recessive hypomyelinating leukodystrophy. Am. J. Hum. Genet. 2011, 89, 415-423.

164. Saitsu, H.; Osaka, H.; Sasaki, M.; Takanashi, J.; Hamada, K.; Yamashita, A.; Shibayama, H.; Shiina, M.; Kondo, Y.; Nishiyama, K.; et al. Mutations in POLR3A and POLR3B encoding RNA Polymerase III subunits cause an autosomal-recessive hypomyelinating leukoencephalopathy. Am. J. Hum. Genet. 2011, 89, 644-651.

165. Tetreault, M.; Choquet, K.; Orcesi, S.; Tonduti, D.; Balottin, U.; Teichmann, M.; Fribourg, S.; Schiffmann, R.; Brais, B.; Vanderver, A.; et al. Recessive mutations in POLR3B, encoding the second largest subunit of Pol III, cause a rare hypomyelinating leukodystrophy. Am. J. Hum. Genet. 2011, 89, 652-655.

166. Schwartz, C.E.; Tarpey, P.S.; Lubs, H.A.; Verloes, A.; May, M.M.; Risheg, H.; Friez, M.J.; Futreal, P.A.; Edkins, S.; Teague, J.; et al. The original Lujan syndrome family has a novel missense mutation (p.N1007S) in the MED12 gene. J. Med. Genet. 2007, 44, 472-477. 
167. Risheg, H.; Graham, J.M., Jr.; Clark, R.D.; Rogers, R.C.; Opitz, J.M.; Moeschler, J.B.; Peiffer, A.P.; May, M.; Joseph, S.M.; Jones, J.R.; et al. A recurrent mutation in MED12 leading to R961W causes Opitz-Kaveggia syndrome. Nat. Genet. 2007, 39, 451-453.

168. Kaufmann, R.; Straussberg, R.; Mandel, H.; Fattal-Valevski, A.; Ben-Zeev, B.; Naamati, A.; Shaag, A.; Zenvirt, S.; Konen, O.; Mimouni-Bloch, A.; et al. Infantile cerebral and cerebellar atrophy is associated with a mutation in the MED17 subunit of the transcription preinitiation mediator complex. Am. J. Hum. Genet. 2010, 87, 667-670.

169. Hashimoto, S.; Boissel, S.; Zarhrate, M.; Rio, M.; Munnich, A.; Egly, J.M.; Colleaux, L. MED23 mutation links intellectual disability to dysregulation of immediate early gene expression. Science 2011, 333, 1161-1163.

170. Leal, A.; Huehne, K.; Bauer, F.; Sticht, H.; Berger, P.; Suter, U.; Morera, B.; Del Valle, G.; Lupski, J.R.; Ekici, A.; et al. Identification of the variant Ala335Val of MED25 as responsible for CMT2B2: molecular data, functional studies of the $\mathrm{SH} 3$ recognition motif and correlation between wild-type MED25 and PMP22 RNA levels in CMT1A animal models. Neurogenetics 2009.

171. Arrand, J.E.; Bone, N.M.; Johnson, R.T. Molecular cloning and characterization of a mammalian excision repair gene that partially restores UV resistance to xeroderma pigmentosum complementation group D cells. Proc. Natl. Acad. Sci. USA 1989, 86, 6997-7001.

172. Graham, J.M., Jr.; Anyane-Yeboa, K.; Raams, A.; Appeldoorn, E.; Kleijer, W.J.; Garritsen, V.H.; Busch, D.; Edersheim, T.G.; Jaspers, N.G. Cerebro-oculo-facio-skeletal syndrome with a nucleotide excision-repair defect and a mutated XPD gene, with prenatal diagnosis in a triplet pregnancy. Am. J. Hum. Genet. 2001, 69, 291-300.

173. Broughton, B.C.; Steingrimsdottir, H.; Weber, C.A.; Lehmann, A.R. Mutations in the xeroderma pigmentosum group D DNA repair/transcription gene in patients with trichothiodystrophy. Nat. Genet. 1994, 7, 189-194.

174. Weeda, G.; van Ham, R.C.; Vermeulen, W.; Bootsma, D.; van der Eb, A.J.; Hoeijmakers, J.H. A presumed DNA helicase encoded by ERCC-3 is involved in the human repair disorders xeroderma pigmentosum and Cockayne's syndrome. Cell 1990, 62, 777-791.

175. Weeda, G.; Eveno, E.; Donker, I.; Vermeulen, W.; Chevallier-Lagente, O.; Taieb, A.; Stary, A.; Hoeijmakers, J.H.; Mezzina, M.; Sarasin, A. A mutation in the XPB/ERCC3 DNA repair transcription gene, associated with trichothiodystrophy. Am. J. Hum. Genet. 1997, 60, 320-329.

176. Giglia-Mari, G.; Coin, F.; Ranish, J.A.; Hoogstraten, D.; Theil, A.; Wijgers, N.; Jaspers, N.G.; Raams, A.; Argentini, M.; van der Spek, P.J.; et al. A new, tenth subunit of TFIIH is responsible for the DNA repair syndrome trichothiodystrophy group A. Nat. Genet. 2004, 36, 714-719.

177. Lefebvre, S.; Burglen, L.; Reboullet, S.; Clermont, O.; Burlet, P.; Viollet, L.; Benichou, B.; Cruaud, C.; Millasseau, P.; Zeviani, M.; et al. Identification and characterization of a spinal muscular atrophy-determining gene. Cell 1995, 80, 155-165.

178. Heiss, N.S.; Knight, S.W.; Vulliamy, T.J.; Klauck, S.M.; Wiemann, S.; Mason, P.J.; Poustka, A.; Dokal, I. X-linked dyskeratosis congenita is caused by mutations in a highly conserved gene with putative nucleolar functions. Nat. Genet. 1998, 19, 32-38. 
179. Knight, S.W.; Heiss, N.S.; Vulliamy, T.J.; Aalfs, C.M.; McMahon, C.; Richmond, P.; Jones, A.; Hennekam, R.C.; Poustka, A.; Mason, P.J.; et al. Unexplained aplastic anaemia, immunodeficiency, and cerebellar hypoplasia (Hoyeraal-Hreidarsson syndrome) due to mutations in the dyskeratosis congenita gene, DKC1. Br. J. Haematol. 1999, 107, 335-339.

180. Vulliamy, T.; Beswick, R.; Kirwan, M.; Marrone, A.; Digweed, M.; Walne, A.; Dokal, I. Mutations in the telomerase component NHP2 cause the premature ageing syndrome dyskeratosis congenita. Proc. Natl. Acad. Sci. USA 2008, 105, 8073-8078.

181. Walne, A.J.; Vulliamy, T.; Marrone, A.; Beswick, R.; Kirwan, M.; Masunari, Y.; Al-Qurashi, F.H.; Aljurf, M.; Dokal, I. Genetic heterogeneity in autosomal recessive dyskeratosis congenita with one subtype due to mutations in the telomerase-associated protein NOP10. Hum. Mol. Genet. 2007, 16, 1619-1629.

182. Armanios, M.; Chen, J.L.; Chang, Y.P.; Brodsky, R.A.; Hawkins, A.; Griffin, C.A.; Eshleman, J.R.; Cohen, A.R.; Chakravarti, A.; Hamosh, A.; et al. Haploinsufficiency of telomerase reverse transcriptase leads to anticipation in autosomal dominant dyskeratosis congenita. Proc. Natl. Acad. Sci. USA 2005, 102, 15960-15964.

183. Marrone, A.; Walne, A.; Tamary, H.; Masunari, Y.; Kirwan, M.; Beswick, R.; Vulliamy, T.; Dokal, I. Telomerase reverse-transcriptase homozygous mutations in autosomal recessive dyskeratosis congenita and Hoyeraal-Hreidarsson syndrome. Blood 2007, 110, 4198-4205.

184. Zhong, F.; Savage, S.A.; Shkreli, M.; Giri, N.; Jessop, L.; Myers, T.; Chen, R.; Alter, B.P.; Artandi, S.E. Disruption of telomerase trafficking by TCAB1 mutation causes dyskeratosis congenita. Genes Dev. 2011, 25, 11-16.

185. Vulliamy, T.; Marrone, A.; Goldman, F.; Dearlove, A.; Bessler, M.; Mason, P.J.; Dokal, I. The RNA component of telomerase is mutated in autosomal dominant dyskeratosis congenita. Nature 2001, 413, 432-435.

186. Cajal, S.R. El núcleo de las células piramidales del cerebro humano y de algunos mamíferos. Trab. Lab. Inv. Biol. Univ. Madr. 1910, 8, 27-62.

187. Beck, J.S. Variations in the morphological patterns of "autoimmune" nuclear fluorescence. Lancet 1961, 1, 1203-1205.

188. Swift, H. Studies on nuclear fine structure. Brookhaven Symp. Biol. 1959, 12, 134-152.

189. Perraud, M.; Gioud, M.; Monier, J.C. Intranuclear structures recognized by autoantibodies against ribonucleoproteins: Study on monkey kidney cells in culture using immunofluorescent techniques and immunoelectron microscopy. Ann. Immunol. (Paris) 1979, 130, 635-647.

190. Lerner, E.A.; Lerner, M.R.; Janeway, C.A., Jr.; Steitz, J.A. Monoclonal antibodies to nucleic acid-containing cellular constituents: Probes for molecular biology and autoimmune disease. Proc. Natl. Acad. Sci. USA 1981, 78, 2737-2741.

191. Spector, D.L.; Schrier, W.H.; Busch, H. Immunoelectron microscopic localization of snRNPs. Biol. Cell 1983, 49, 1-10.

192. Girard, C.; Will, C.L.; Peng, J.; Makarov, E.M.; Kastner, B.; Lemm, I.; Urlaub, H.; Hartmuth, K.; Luhrmann, R. Post-transcriptional spliceosomes are retained in nuclear speckles until splicing completion. Nat. Commun. 2012, 3, 994.

193. Lin, S.; Coutinho-Mansfield, G.; Wang, D.; Pandit, S.; Fu, X.D. The splicing factor SC35 has an active role in transcriptional elongation. Nat. Struct. Mol. Biol. 2008, 15, 819-826. 
194. Zhong, X.Y.; Wang, P.; Han, J.; Rosenfeld, M.G.; Fu, X.D. SR proteins in vertical integration of gene expression from transcription to RNA processing to translation. Mol. Cell 2009, 35, 1-10.

195. Chang, Y.F.; Imam, J.S.; Wilkinson, M.F. The nonsense-mediated decay RNA surveillance pathway. Annu. Rev. Biochem. 2007, 76, 51-74.

196. Wei, X.; Somanathan, S.; Samarabandu, J.; Berezney, R. Three-dimensional visualization of transcription sites and their association with splicing factor-rich nuclear speckles. J. Cell Biol. 1999, 146, 543-558.

197. Long, J.C.; Caceres, J.F. The SR protein family of splicing factors: Master regulators of gene expression. Biochem. J. 2009, 417, 15-27.

198. Misteli, T.; Caceres, J.F.; Clement, J.Q.; Krainer, A.R.; Wilkinson, M.F.; Spector, D.L. Serine phosphorylation of SR proteins is required for their recruitment to sites of transcription in vivo. J. Cell Biol. 1998, 143, 297-307.

199. Strasser, K.; Masuda, S.; Mason, P.; Pfannstiel, J.; Oppizzi, M.; Rodriguez-Navarro, S.; Rondon, A.G.; Aguilera, A.; Struhl, K.; Reed, R.; et al. TREX is a conserved complex coupling transcription with messenger RNA export. Nature 2002, 417, 304-308.

200. Cmarko, D.; Verschure, P.J.; Martin, T.E.; Dahmus, M.E.; Krause, S.; Fu, X.D.; van Driel, R.; Fakan, S. Ultrastructural analysis of transcription and splicing in the cell nucleus after bromoUTP microinjection. Mol. Biol. Cell 1999, 10, 211-223.

201. Jolly, C.; Usson, Y.; Morimoto, R.I. Rapid and reversible relocalization of heat shock factor 1 within seconds to nuclear stress granules. Proc. Natl. Acad. Sci. USA 1999, 96, 6769-6774.

202. Cotto, J.; Fox, S.; Morimoto, R. HSF1 granules: A novel stress-induced nuclear compartment of human cells. J. Cell Sci. 1997, 110, 2925-2934.

203. Denegri, M.; Moralli, D.; Rocchi, M.; Biggiogera, M.; Raimondi, E.; Cobianchi, F.; De Carli, L.; Riva, S.; Biamonti, G. Human chromosomes 9, 12, and 15 contain the nucleation sites of stressinduced nuclear bodies. Mol. Biol. Cell 2002, 13, 2069-2079.

204. Morton, E.A.; Lamitina, T. Caenorhabditis elegans HSF-1 is an essential nuclear protein that forms stress granule-like structures following heat shock. Aging Cell 2012.

205. Prasanth, K.V.; Rajendra, T.K.; Lal, A.K.; Lakhotia, S.C. Omega speckles - a novel class of nuclear speckles containing hnRNPs associated with noncoding hsr-omega RNA in Drosophila. J. Cell Sci. 2000, 113, 3485-3497.

206. Mahl, P.; Lutz, Y.; Puvion, E.; Fuchs, J.P. Rapid effect of heat shock on two heterogeneous nuclear ribonucleoprotein-associated antigens in HeLa cells. J. Cell Biol. 1989, 109, 1921-1935.

207. Xiao, H.; Lis, J.T. Germline transformation used to define key features of heat-shock response elements. Science 1988, 239, 1139-1142.

208. Jolly, C.; Konecny, L.; Grady, D.L.; Kutskova, Y.A.; Cotto, J.J.; Morimoto, R.I.; Vourc'h, C. In vivo binding of active heat shock transcription factor 1 to human chromosome 9 heterochromatin during stress. J. Cell Biol. 2002, 156, 775-781.

209. Oesterreich, S.; Lee, A.V.; Sullivan, T.M.; Samuel, S.K.; Davie, J.R.; Fuqua, S.A. Novel nuclear matrix protein HET binds to and influences activity of the HSP27 promoter in human breast cancer cells. J. Cell. Biochem. 1997, 67, 275-286. 
210. Townson, S.M.; Kang, K.; Lee, A.V.; Oesterreich, S. Structure-function analysis of the estrogen receptor alpha corepressor scaffold attachment factor-B1: identification of a potent transcriptional repression domain. J. Biol. Chem. 2004, 279, 26074-26081.

211. Montgomery, T.H. Comparative cytological studies, with especial regard to the morphology of the nucleolus. J. Morphol. 1898, 15, 265-582.

212. Islinger, M.; Willimski, D.; Volk1, A.; Braunbeck, T. Effects of 17a-ethinylestradiol on the expression of three estrogen-responsive genes and cellular ultrastructure of liver and testes in male zebrafish. Aquat. Toxicol. 2003, 62, 85-103.

213. Knibiehler, B.; Mirre, C.; Rosset, R. Nucleolar organizer structure and activity in a nucleolus without fibrillar centres: The nucleolus in an established Drosophila cell line. J. Cell Sci. 1982, $57,351-364$.

214. Lee, L.W.; Lee, C.C.; Huang, C.R.; Lo, S.J. The nucleolus of Caenorhabditis elegans. J. Biomed. Biotechnol. 2012, 2012, 601274.

215. Smitt, W.W.; Vlak, J.M.; Molenaar, I.; Rozijn, T.H. Nucleolar function of the dense crescent in the yeast nucleus. A biochemical and ultrastructural study. Exp. Cell Res. 1973, 80, 313-321.

216. Monneron, A.; Bernhard, W. Fine structural organization of the interphase nucleus in some mammalian cells. J. Ultrastruct. Res. 1969, 27, 266-288.

217. Wu, Z.A.; Murphy, C.; Callan, H.G.; Gall, J.G. Small nuclear ribonucleoproteins and heterogeneous nuclear ribonucleoproteins in the amphibian germinal vesicle: loops, spheres, and snurposomes. J. Cell Biol. 1991, 113, 465-483.

218. Segalat, L.; Lepesant, J.A. Spatial distribution of the Sm antigen in Drosophila early embryos. Biol. Cell 1992, 75, 181-185.

219. Potashkin, J.A.; Derby, R.J.; Spector, D.L. Differential distribution of factors involved in pre-mRNA processing in the yeast cell nucleus. Mol. Cell. Biol. 1990, 10, 3524-3534.

220. Schoenfelder, S.; Sexton, T.; Chakalova, L.; Cope, N.F.; Horton, A.; Andrews, S.; Kurukuti, S.; Mitchell, J.A.; Umlauf, D.; Dimitrova, D.S.; et al. Preferential associations between co-regulated genes reveal a transcriptional interactome in erythroid cells. Nat. Genet. 2010, 42, 53-61.

221. Cajal, S.R. Un sencillo método de coloración seletiva del retículo protoplasmático y sus efectos en los diversos órganos nerviosos de vertebrados e invertebrados. Trab. Lab. Inv. Biol. Univ. Madr. 1903, 2, 129-221.

222. Nizami, Z.F.; Gall, J.G. Pearls are novel Cajal body-like structures in the Xenopus germinal vesicle that are dependent on RNA pol III transcription. Chromosome Res. 2012, 20, 953-969.

223. Strzelecka, M.; Oates, A.C.; Neugebauer, K.M. Dynamic control of Cajal body number during zebrafish embryogenesis. Nucleus 2010, 1, 96-108.

224. Verheggen, C.; Mouaikel, J.; Thiry, M.; Blanchard, J.M.; Tollervey, D.; Bordonne, R.; Lafontaine, D.L.; Bertrand, E. Box C/D small nucleolar RNA trafficking involves small nucleolar RNP proteins, nucleolar factors and a novel nuclear domain. EMBO J. 2001, 20, 5480-5490.

225. Francis, J.W.; Sandrock, A.W.; Bhide, P.G.; Vonsattel, J.P.; Brown, R.H., Jr. Heterogeneity of subcellular localization and electrophoretic mobility of survival motor neuron (SMN) protein in mammalian neural cells and tissues. Proc. Natl. Acad. Sci. USA 1998, 95, 6492-6497.

226. Cauchi, R.J. Gem formation upon constitutive Gemin3 overexpression in Drosophila. Cell Biol. Int. 2011, 35, 1233-1238. 
227. Wu, C.H.; Gall, J.G. U7 small nuclear RNA in C snurposomes of the Xenopus germinal vesicle. Proc. Natl. Acad. Sci. USA 1993, 90, 6257-6259.

228. Bongiorno-Borbone, L.; De Cola, A.; Vernole, P.; Finos, L.; Barcaroli, D.; Knight, R.A.; Melino, G.; De Laurenzi, V. FLASH and NPAT positive but not Coilin positive Cajal Bodies correlate with cell ploidy. Cell Cycle 2008, 7, 2357-2367.

229. Ge, H.; Manley, J.L. A protein factor, ASF, controls cell-specific alternative splicing of SV40 early pre-mRNA in vitro. Cell 1990, 62, 25-34.

230. Wu, H.; Sun, S.; Tu, K.; Gao, Y.; Xie, B.; Krainer, A.R.; Zhu, J. A splicing-independent function of SF2/ASF in microRNA processing. Mol. Cell 2010, 38, 67-77.

231. Jolly, C.; Vourc'h, C.; Robert-Nicoud, M.; Morimoto, R.I. Intron-independent association of splicing factors with active genes. J. Cell Biol. 1999, 145, 1133-1143.

232. Fu, X.D. Specific commitment of different pre-mRNAs to splicing by single SR proteins. Nature 1993, 365, 82-85.

233. Busa, R.; Geremia, R.; Sette, C. Genotoxic stress causes the accumulation of the splicing regulator Sam68 in nuclear foci of transcriptionally active chromatin. Nucleic Acids Res. 2010, 38, 3005-3018.

234. Metz, A.; Soret, J.; Vourc'h, C.; Tazi, J.; Jolly, C. A key role for stress-induced satellite III transcripts in the relocalization of splicing factors into nuclear stress granules. J. Cell Sci. 2004, $117,4551-4558$.

235. Shevtsov, S.P.; Dundr, M. Nucleation of nuclear bodies by RNA. Nat. Cell Biol. 2011, 13, 167-173.

236. Fritah, S.; Col, E.; Boyault, C.; Govin, J.; Sadoul, K.; Chiocca, S.; Christians, E.; Khochbin, S.; Jolly, C.; Vourc'h, C. Heat-shock factor 1 controls genome-wide acetylation in heat-shocked cells. Mol. Biol. Cell 2009, 20, 4976-4984.

237. Papantonis, A.; Larkin, J.D.; Wada, Y.; Ohta, Y.; Ihara, S.; Kodama, T.; Cook, P.R. Active RNA polymerases: Mobile or immobile molecular machines? PLoS Biol. 2010, 8, e1000419.

238. Dickinson, P.; Cook, P.R.; Jackson, D.A. Active RNA polymerase I is fixed within the nucleus of HeLa cells. EMBO J. 1990, 9, 2207-2214.

239. Mitchell, J.A.; Fraser, P. Transcription factories are nuclear subcompartments that remain in the absence of transcription. Genes Dev. 2008, 22, 20-25.

240. Cook, P.R. Predicting three-dimensional genome structure from transcriptional activity. Nat. Genet. 2002, 32, 347-352.

241. McCracken, S.; Fong, N.; Yankulov, K.; Ballantyne, S.; Pan, G.; Greenblatt, J.; Patterson, S.D.; Wickens, M.; Bentley, D.L. The C-terminal domain of RNA polymerase II couples mRNA processing to transcription. Nature 1997, 385, 357-361.

242. Gall, J.G. The centennial of the Cajal body. Nat. Rev. Mol. Cell Biol. 2003, 4, 975-980.

243. Dundr, M. Nuclear bodies: Multifunctional companions of the genome. Curr. Opin. Cell Biol. 2012, 24, 415-422.

244. Machyna, M.; Heyn, P.; Neugebauer, K.M. Cajal bodies: Where form meets function. Wiley Interdiscip Rev RNA 2013, 4, 17-34.

245. Jady, B.E.; Bertrand, E.; Kiss, T. Human telomerase RNA and box H/ACA scaRNAs share a common Cajal body-specific localization signal. J. Cell Biol. 2004, 164, 647-652. 
246. Baillat, D.; Hakimi, M.A.; Naar, A.M.; Shilatifard, A.; Cooch, N.; Shiekhattar, R. Integrator, a multiprotein mediator of small nuclear RNA processing, associates with the C-terminal repeat of RNA polymerase II. Cell 2005, 123, 265-276.

247. Takata, H.; Nishijima, H.; Maeshima, K.; Shibahara, K. The integrator complex is required for integrity of Cajal bodies. J. Cell Sci. 2012, 125, 166-175.

248. Xu, H.; Pillai, R.S.; Azzouz, T.N.; Shpargel, K.B.; Kambach, C.; Hebert, M.D.; Schumperli, D.; Matera, A.G. The C-terminal domain of coilin interacts with Sm proteins and U snRNPs. Chromosoma 2005, 114, 155-166.

249. Broome, H.J.; Hebert, M.D. Coilin displays differential affinity for specific RNAs in vivo and is linked to telomerase RNA biogenesis. J. Mol. Biol. 2013.

250. Hebert, M.D.; Szymczyk, P.W.; Shpargel, K.B.; Matera, A.G. Coilin forms the bridge between Cajal bodies and SMN, the spinal muscular atrophy protein. Genes Dev. 2001, 15, 2720-2729.

251. Broome, H.J.; Hebert, M.D. In vitro RNase and nucleic acid binding activities implicate coilin in U snRNA processing. PLoS One 2012, 7, e36300.

252. Sleeman, J.E.; Lamond, A.I. Newly assembled snRNPs associate with coiled bodies before speckles, suggesting a nuclear snRNP maturation pathway. Curr. Biol. 1999, 9, 1065-1074.

253. Stanek, D.; Neugebauer, K.M. Detection of snRNP assembly intermediates in Cajal bodies by fluorescence resonance energy transfer. J. Cell Biol. 2004, 166, 1015-1025.

254. Nesic, D.; Tanackovic, G.; Kramer, A. A role for Cajal bodies in the final steps of U2 snRNP biogenesis. J. Cell Sci. 2004, 117, 4423-4433.

255. Kiss, T.; Fayet, E.; Jady, B.E.; Richard, P.; Weber, M. Biogenesis and intranuclear trafficking of human box C/D and H/ACA RNPs. Cold Spring Harb. Symp. Quant. Biol. 2006, 71, 407-417.

256. Mahmoudi, S.; Henriksson, S.; Weibrecht, I.; Smith, S.; Soderberg, O.; Stromblad, S.; Wiman, K.G.; Farnebo, M. WRAP53 is essential for Cajal body formation and for targeting the survival of motor neuron complex to Cajal bodies. PLoS Biol. 2010, 8, e1000521.

257. Davis, D.R. Stabilization of RNA stacking by pseudouridine. Nucleic Acids Res. 1995, 23, 5020-5026.

258. Wu, G.; Xiao, M.; Yang, C.; Yu, Y.T. U2 snRNA is inducibly pseudouridylated at novel sites by Pus7p and snR81 RNP. EMBO J. 2011, 30, 79-89.

259. Frey, M.R.; Bailey, A.D.; Weiner, A.M.; Matera, A.G. Association of snRNA genes with coiled bodies is mediated by nascent snRNA transcripts. Curr. Biol. 1999, 9, 126-135.

260. Smith, K.P.; Carter, K.C.; Johnson, C.V.; Lawrence, J.B. U2 and U1 snRNA gene loci associate with coiled bodies. J. Cell. Biochem. 1995, 59, 473-485.

261. Smith, K.P.; Lawrence, J.B. Interactions of U2 gene loci and their nuclear transcripts with Cajal (coiled) bodies: Evidence for PreU2 within Cajal bodies. Mol. Biol. Cell 2000, 11, 2987-2998.

262. Sleeman, J.E.; Lamond, A.I. Newly assembled snRNPs associate with coiled bodies before speckles, suggesting a nuclear snRNP maturation pathway. Curr. Biol. 1999, 9, 1065-1074.

263. Cristofari, G.; Adolf, E.; Reichenbach, P.; Sikora, K.; Terns, R.M.; Terns, M.P.; Lingner, J. Human telomerase RNA accumulation in Cajal bodies facilitates telomerase recruitment to telomeres and telomere elongation. Mol. Cell 2007, 27, 882-889. 
264. Tomlinson, R.L.; Abreu, E.B.; Ziegler, T.; Ly, H.; Counter, C.M.; Terns, R.M.; Terns, M.P. Telomerase reverse transcriptase is required for the localization of telomerase RNA to Cajal bodies and telomeres in human cancer cells. Mol. Biol. Cell 2008, 19, 3793-3800.

265. Tomlinson, R.L.; Ziegler, T.D.; Supakorndej, T.; Terns, R.M.; Terns, M.P. Cell cycle-regulated trafficking of human telomerase to telomeres. Mol. Biol. Cell 2006, 17, 955-965.

266. Jady, B.E.; Richard, P.; Bertrand, E.; Kiss, T. Cell cycle-dependent recruitment of telomerase RNA and Cajal bodies to human telomeres. Mol. Biol. Cell 2006, 17, 944-954.

267. Werdnig, G. Zwei frühinfantile hereditäre fälle von progressiver muskelatrophie unter dem bilde der dystrophie, aber auf neurotischer grundlage. Arch. Psychiatr. Nervenkr. 1891, 22, 437-481.

268. Hoffmann, J. Weitere beiträge zur lehre von der progressiven neurotischen muskeldystrophie. Dtsch. Z. Nervenheilkd. 1891, 1, 95-120.

269. Strasswimmer, J.; Lorson, C.L.; Breiding, D.E.; Chen, J.J.; Le, T.; Burghes, A.H.; Androphy, E.J. Identification of survival motor neuron as a transcriptional activator-binding protein. Hum. Mol. Genet. 1999, 8, 1219-1226.

270. Pellizzoni, L.; Charroux, B.; Rappsilber, J.; Mann, M.; Dreyfuss, G. A functional interaction between the survival motor neuron complex and RNA polymerase II. J. Cell Biol. 2001, 152, 75-85.

271. Sanchez, G.; Dury, A.Y.; Murray, L.M.; Biondi, O.; Tadesse, H.; El Fatimy, R.; Kothary, R.; Charbonnier, F.; Khandjian, E.W.; Cote, J. A novel function for the survival motoneuron protein as a translational regulator. Hum. Mol. Genet. 2012.

272. Battle, D.J.; Lau, C.K.; Wan, L.; Deng, H.; Lotti, F.; Dreyfuss, G. The Gemin5 protein of the SMN complex identifies snRNAs. Mol. Cell 2006, 23, 273-279.

273. Galcheva-Gargova, Z.; Gangwani, L.; Konstantinov, K.N.; Mikrut, M.; Theroux, S.J.; Enoch, T.; Davis, R.J. The cytoplasmic zinc finger protein ZPR1 accumulates in the nucleolus of proliferating cells. Mol. Biol. Cell 1998, 9, 2963-2971.

274. Galcheva-Gargova, Z.; Konstantinov, K.N.; Wu, I.H.; Klier, F.G.; Barrett, T.; Davis, R.J. Binding of zinc finger protein ZPR1 to the epidermal growth factor receptor. Science 1996, 272, 1797-1802.

275. Hebert, M.D.; Shpargel, K.B.; Ospina, J.K.; Tucker, K.E.; Matera, A.G. Coilin methylation regulates nuclear body formation. Dev. Cell 2002, 3, 329-337.

276. Shafey, D.; Cote, P.D.; Kothary, R. Hypomorphic Smn knockdown C2C12 myoblasts reveal intrinsic defects in myoblast fusion and myotube morphology. Exp. Cell Res. 2005, 311, 49-61.

277. Yang, X.C.; Sabath, I.; Debski, J.; Kaus-Drobek, M.; Dadlez, M.; Marzluff, W.F.; Dominski, Z. A complex containing the CPSF73 endonuclease and other polyadenylation factors associates with U7 snRNP and is recruited to histone pre-mRNA for 3'-end processing. Mol. Cell. Biol. 2013, 33, 28-37.

278. Sanchez, R.; Marzluff, W.F. The stem-loop binding protein is required for efficient translation of histone mRNA in vivo and in vitro. Mol. Cell. Biol. 2002, 22, 7093-7104.

279. Krishnan, N.; Lam, T.T.; Fritz, A.; Rempinski, D.; O'Loughlin, K.; Minderman, H.; Berezney, R.; Marzluff, W.F.; Thapar, R. The prolyl isomerase Pin1 targets stem-loop binding protein (SLBP) to dissociate the SLBP-histone mRNA complex linking histone mRNA decay with SLBP ubiquitination. Mol. Cell. Biol. 2012, 32, 4306-4322. 
280. Fox, A.H.; Bond, C.S.; Lamond, A.I. p54nrb forms a heterodimer with PSP1 that localizes to paraspeckles in an RNA-dependent manner. Mol. Biol. Cell 2005, 16, 5304-5315.

281. Naganuma, T.; Nakagawa, S.; Tanigawa, A.; Sasaki, Y.F.; Goshima, N.; Hirose, T. Alternative 3 '-end processing of long noncoding RNA initiates construction of nuclear paraspeckles. EMBO J. 2012, 31, 4020-4034.

282. Rosonina, E.; Ip, J.Y.; Calarco, J.A.; Bakowski, M.A.; Emili, A.; McCracken, S.; Tucker, P.; Ingles, C.J.; Blencowe, B.J. Role for PSF in mediating transcriptional activator-dependent stimulation of pre-mRNA processing in vivo. Mol. Cell. Biol. 2005, 25, 6734-6746.

283. Kaneko, S.; Rozenblatt-Rosen, O.; Meyerson, M.; Manley, J.L. The multifunctional protein $\mathrm{p} 54 \mathrm{nrb} / \mathrm{PSF}$ recruits the exonuclease XRN2 to facilitate pre-mRNA 3' processing and transcription termination. Genes Dev. 2007, 21, 1779-1789.

284. Patton, J.G.; Porro, E.B.; Galceran, J.; Tempst, P.; Nadal-Ginard, B. Cloning and characterization of PSF, a novel pre-mRNA splicing factor. Genes Dev. 1993, 7, 393-406.

285. Peng, R.; Dye, B.T.; Perez, I.; Barnard, D.C.; Thompson, A.B.; Patton, J.G. PSF and p54nrb bind a conserved stem in U5 snRNA. RNA 2002, 8, 1334-1347.

286. Kameoka, S.; Duque, P.; Konarska, M.M. p54(nrb) associates with the 5' splice site within large transcription/splicing complexes. EMBO J. 2004, 23, 1782-1791.

287. Bladen, C.L.; Udayakumar, D.; Takeda, Y.; Dynan, W.S. Identification of the polypyrimidine tract binding protein-associated splicing factor p54(nrb) complex as a candidate DNA doublestrand break rejoining factor. J. Biol. Chem. 2005, 280, 5205-5210.

288. Li, S.; Kuhne, W.W.; Kulharya, A.; Hudson, F.Z.; Ha, K.; Cao, Z.; Dynan, W.S. Involvement of p54(nrb), a PSF partner protein, in DNA double-strand break repair and radioresistance. Nucleic Acids Res. 2009, 37, 6746-6753.

289. Salton, M.; Lerenthal, Y.; Wang, S.Y.; Chen, D.J.; Shiloh, Y. Involvement of Matrin 3 and SFPQ/NONO in the DNA damage response. Cell Cycle 2010, 9, 1568-1576.

290. Ha, K.; Takeda, Y.; Dynan, W.S. Sequences in PSF/SFPQ mediate radioresistance and recruitment of PSF/SFPQ-containing complexes to DNA damage sites in human cells. DNA Repair (Amst) 2011, 10, 252-259.

291. Lowery, L.A.; Rubin, J.; Sive, H. Whitesnake/sfpq is required for cell survival and neuronal development in the zebrafish. Dev. Dyn. 2007, 236, 1347-1357.

292. Auboeuf, D.; Dowhan, D.H.; Li, X.; Larkin, K.; Ko, L.; Berget, S.M.; O'Malley, B.W. CoAA, a nuclear receptor coactivator protein at the interface of transcriptional coactivation and RNA splicing. Mol. Cell. Biol. 2004, 24, 442-453.

293. Ruegsegger, U.; Beyer, K.; Keller, W. Purification and characterization of human cleavage factor Im involved in the $3^{\prime}$ end processing of messenger RNA precursors. J. Biol. Chem. 1996, 271, 6107-6113.

294. Ruepp, M.D.; Aringhieri, C.; Vivarelli, S.; Cardinale, S.; Paro, S.; Schumperli, D.; Barabino, S.M. Mammalian pre-mRNA 3' end processing factor CF I m 68 functions in mRNA export. Mol. Biol. Cell 2009, 20, 5211-5223.

295. Zhang, Z.; Carmichael, G.G. The fate of dsRNA in the nucleus: A p54(nrb)-containing complex mediates the nuclear retention of promiscuously A-to-I edited RNAs. Cell 2001, 106, 465-475. 
296. Moncada, S.; Higgs, A. The L-arginine-nitric oxide pathway. N. Engl. J. Med. 1993, 329, 2002-2012.

297. Herman, R.C.; Williams, J.G.; Penman, S. Message and non-message sequences adjacent to poly(A) in steady state heterogeneous nuclear RNA of HeLa cells. Cell 1976, 7, 429-437.

298. Athanasiadis, A.; Rich, A.; Maas, S. Widespread A-to-I RNA editing of Alu-containing mRNAs in the human transcriptome. PLoS Biol. 2004, 2, e391.

299. Kim, D.D.; Kim, T.T.; Walsh, T.; Kobayashi, Y.; Matise, T.C.; Buyske, S.; Gabriel, A. Widespread RNA editing of embedded alu elements in the human transcriptome. Genome Res. 2004, 14, 1719-1725.

300. Levanon, E.Y.; Eisenberg, E.; Yelin, R.; Nemzer, S.; Hallegger, M.; Shemesh, R.; Fligelman, Z.Y.; Shoshan, A.; Pollock, S.R.; Sztybel, D.; et al. Systematic identification of abundant A-to-I editing sites in the human transcriptome. Nat. Biotechnol. 2004, 22, 1001-1005.

301. Rabl, C. Über Zelltheilung. Morphol. Jahrbuch 1885, 10, 214-330.

302. Bischoff, A.; Albers, J.; Kharboush, I.; Stelzer, E.; Cremer, T.; Cremer, C. Differences of size and shape of active and inactive $\mathrm{X}$-chromosome domains in human amniotic fluid cell nuclei. Microsc. Res. Tech. 1993, 25, 68-77.

303. Cremer, T.; Cremer, C. Chromosome territories, nuclear architecture and gene regulation in mammalian cells. Nat. Rev. Genet. 2001, 2, 292-301.

304. Cremer, T.; Lichter, P.; Borden, J.; Ward, D.C.; Manuelidis, L. Detection of chromosome aberrations in metaphase and interphase tumor cells by in situ hybridization using chromosomespecific library probes. Hum. Genet. 1988, 80, 235-246.

305. Lichter, P.; Cremer, T.; Borden, J.; Manuelidis, L.; Ward, D.C. Delineation of individual human chromosomes in metaphase and interphase cells by in situ suppression hybridization using recombinant DNA libraries. Hum. Genet. 1988, 80, 224-234.

306. Pinkel, D.; Landegent, J.; Collins, C.; Fuscoe, J.; Segraves, R.; Lucas, J.; Gray, J. Fluorescence in situ hybridization with human chromosome-specific libraries: detection of trisomy 21 and translocations of chromosome 4. Proc. Natl. Acad. Sci. USA 1988, 85, 9138-9142.

307. Chambeyron, S.; Bickmore, W.A. Chromatin decondensation and nuclear reorganization of the HoxB locus upon induction of transcription. Genes Dev. 2004, 18, 1119-1130.

308. Chambeyron, S.; Da Silva, N.R.; Lawson, K.A.; Bickmore, W.A. Nuclear re-organisation of the Hoxb complex during mouse embryonic development. Development 2005, 132, 2215-2223.

309. Dietzel, S.; Schiebel, K.; Little, G.; Edelmann, P.; Rappold, G.A.; Eils, R.; Cremer, C.; Cremer, T. The 3D positioning of ANT2 and ANT3 genes within female X chromosome territories correlates with gene activity. Exp. Cell Res. 1999, 252, 363-375.

310. Ferrai, C.; Xie, S.Q.; Luraghi, P.; Munari, D.; Ramirez, F.; Branco, M.R.; Pombo, A.; Crippa, M.P. Poised transcription factories prime silent uPA gene prior to activation. PLoS Biol. 2010, 8, e1000270.

311. Kurz, A.; Lampel, S.; Nickolenko, J.E.; Bradl, J.; Benner, A.; Zirbel, R.M.; Cremer, T.; Lichter, P. Active and inactive genes localize preferentially in the periphery of chromosome territories. $J$. Cell Biol. 1996, 135, 1195-1205. 
312. Mahy, N.L.; Perry, P.E.; Bickmore, W.A. Gene density and transcription influence the localization of chromatin outside of chromosome territories detectable by FISH. J. Cell Biol. 2002, 159, 753-763.

313. Mahy, N.L.; Perry, P.E.; Gilchrist, S.; Baldock, R.A.; Bickmore, W.A. Spatial organization of active and inactive genes and noncoding DNA within chromosome territories. J. Cell Biol. 2002, 157, 579-589.

314. Morey, C.; Da Silva, N.R.; Perry, P.; Bickmore, W.A. Nuclear reorganisation and chromatin decondensation are conserved, but distinct, mechanisms linked to Hox gene activation. Development 2007, 134, 909-919.

315. Scheuermann, M.O.; Tajbakhsh, J.; Kurz, A.; Saracoglu, K.; Eils, R.; Lichter, P. Topology of genes and nontranscribed sequences in human interphase nuclei. Exp. Cell Res. 2004, 301, 266-279.

316. Volpi, E.V.; Chevret, E.; Jones, T.; Vatcheva, R.; Williamson, J.; Beck, S.; Campbell, R.D.; Goldsworthy, M.; Powis, S.H.; Ragoussis, J.; et al. Large-scale chromatin organization of the major histocompatibility complex and other regions of human chromosome 6 and its response to interferon in interphase nuclei. J. Cell Sci. 2000, 113, 1565-1576.

317. Williams, R.R.; Broad, S.; Sheer, D.; Ragoussis, J. Subchromosomal positioning of the epidermal differentiation complex (EDC) in keratinocyte and lymphoblast interphase nuclei. Exp. Cell Res. 2002, 272, 163-175.

318. Bridger, J.M.; Herrmann, H.; Munkel, C.; Lichter, P. Identification of an interchromosomal compartment by polymerization of nuclear-targeted vimentin. J. Cell Sci. 1998, 111, 1241-1253.

319. Clemson, C.M.; Lawrence, J.B. Multifunctional compartments in the nucleus: Insights from DNA and RNA localization. J. Cell. Biochem. 1996, 62, 181-190.

320. Lampel, S.; Bridger, J.M.; Zirbel, R.M.; Mathieu, U.R.; Lichter, P. Nuclear RNA accumulations contain released transcripts and exhibit specific distributions with respect to Sm antigen foci. DNA Cell Biol. 1997, 16, 1133-1142.

321. Xing, Y.; Johnson, C.V.; Moen, P.T., Jr.; McNeil, J.A.; Lawrence, J. Nonrandom gene organization: Structural arrangements of specific pre-mRNA transcription and splicing with SC35 domains. J. Cell Biol. 1995, 131, 1635-1647.

322. Zirbel, R.M.; Mathieu, U.R.; Kurz, A.; Cremer, T.; Lichter, P. Evidence for a nuclear compartment of transcription and splicing located at chromosome domain boundaries. Chromosome Res. 1993, 1, 93-106.

323. Bickmore, W.A.; Chubb, J.R. Dispatch. Chromosome position: Now, where was I? Curr. Biol. 2003, 13, R357-R359.

324. Gerlich, D.; Beaudouin, J.; Kalbfuss, B.; Daigle, N.; Eils, R.; Ellenberg, J. Global chromosome positions are transmitted through mitosis in mammalian cells. Cell 2003, 112, 751-764.

325. Parada, L.A.; Roix, J.J.; Misteli, T. An uncertainty principle in chromosome positioning. Trends Cell Biol. 2003, 13, 393-396.

326. Walter, J.; Schermelleh, L.; Cremer, M.; Tashiro, S.; Cremer, T. Chromosome order in HeLa cells changes during mitosis and early G1, but is stably maintained during subsequent interphase stages. J. Cell Biol. 2003, 160, 685-697.

327. Williams, R.R.; Fisher, A.G. Chromosomes, positions please! Nat. Cell Biol. 2003, 5, 388-390. 
328. Harewood, L.; Schutz, F.; Boyle, S.; Perry, P.; Delorenzi, M.; Bickmore, W.A.; Reymond, A. The effect of translocation-induced nuclear reorganization on gene expression. Genome Res. 2010, 20, 554-564.

329. Campalans, A.; Amouroux, R.; Bravard, A.; Epe, B.; Radicella, J.P. UVA irradiation induces relocalisation of the DNA repair protein hOGG1 to nuclear speckles. J. Cell Sci. 2007, 120, 23-32.

330. Ishitani, K.; Yoshida, T.; Kitagawa, H.; Ohta, H.; Nozawa, S.; Kato, S. p54nrb acts as a transcriptional coactivator for activation function 1 of the human androgen receptor. Biochem. Biophys. Res. Commun. 2003, 306, 660-665.

331. Kuwahara, S.; Ikei, A.; Taguchi, Y.; Tabuchi, Y.; Fujimoto, N.; Obinata, M.; Uesugi, S.; Kurihara, Y. PSPC1, NONO, and SFPQ are expressed in mouse Sertoli cells and may function as coregulators of androgen receptor-mediated transcription. Biol. Reprod. 2006, 75, 352-359.

332. Mayer, C.; Bierhoff, H.; Grummt, I. The nucleolus as a stress sensor: JNK2 inactivates the transcription factor TIF-IA and down-regulates rRNA synthesis. Genes Dev. 2005, 19, 933-941.

333. Velma, V.; Carrero, Z.I.; Cosman, A.M.; Hebert, M.D. Coilin interacts with Ku proteins and inhibits in vitro non-homologous DNA end joining. FEBS Lett. 2010, 584, 4735-4739.

334. Xu, M.; Cook, P.R. The role of specialized transcription factories in chromosome pairing. Biochim. Biophys. Acta 2008, 1783, 2155-2160.

335. Zhao, J.; Kennedy, B.K.; Lawrence, B.D.; Barbie, D.A.; Matera, A.G.; Fletcher, J.A.; Harlow, E. NPAT links cyclin E-Cdk2 to the regulation of replication-dependent histone gene transcription. Genes Dev. 2000, 14, 2283-2297.

336. Mao, Y.S.; Zhang, B.; Spector, D.L. Biogenesis and function of nuclear bodies. Trends Genet. 2011, 27, 295-306.

337. Dundr, M.; Misteli, T. Biogenesis of nuclear bodies. Cold Spring Harb. Perspect. Biol. 2010, 2 , a000711.

338. Shav-Tal, Y.; Blechman, J.; Darzacq, X.; Montagna, C.; Dye, B.T.; Patton, J.G.; Singer, R.H.; Zipori, D. Dynamic sorting of nuclear components into distinct nucleolar caps during transcriptional inhibition. Mol. Biol. Cell 2005, 16, 2395-2413.

339. Spector, D.L.; Fu, X.D.; Maniatis, T. Associations between distinct pre-mRNA splicing components and the cell nucleus. EMBO J. 1991, 10, 3467-3481.

340. Young, P.J.; Le, T.T.; Dunckley, M.; Nguyen, T.M.; Burghes, A.H.; Morris, G.E. Nuclear gems and Cajal (coiled) bodies in fetal tissues: nucleolar distribution of the spinal muscular atrophy protein, SMN. Exp. Cell Res. 2001, 265, 252-261.

341. Gdula, M.R.; Poterlowicz, K.; Mardaryev, A.N.; Sharov, A.A.; Peng, Y.; Fessing, M.Y.; Botchkarev, V.A. Remodeling of Three-Dimensional Organization of the Nucleus during Terminal Keratinocyte Differentiation in the Epidermis. J. Invest. Dermatol. 2013.

342. Berrios, S.; Fernandez-Donoso, R.; Pincheira, J.; Page, J.; Manterola, M.; Cerda, M.C. Number and nuclear localisation of nucleoli in mammalian spermatocytes. Genetica 2004, 121, 219-228.

343. McClintock, B. The relation of a particular chromosomal element to the development of the nucleoli in Zea mays. Z. Zellforsch. 1934, 21, 294-328.

344. Pardue, M.L.; Hsu, T.C. Locations of $18 \mathrm{~S}$ and $28 \mathrm{~S}$ ribosomal genes on the chromosomes of the Indian muntjac. J. Cell Biol. 1975, 64, 251-254. 
345. Lima-de-Faria, A. The relation between chromomeres, replicons, operons, transcription units, genes, viruses and palindromes. Hereditas 1975, 81, 249-284.

346. Lima-de-Faria, A. Classification of genes, rearrangements and chromosomes according to the chromosome field. Hereditas 1980, 93, 1-46.

347. Thatcher, T.H.; Gorovsky, M.A. Phylogenetic analysis of the core histones H2A, H2B, H3, and H4. Nucleic Acids Res. 1994, 22, 174-179.

(C) 2013 by the authors; licensee MDPI, Basel, Switzerland. This article is an open access article distributed under the terms and conditions of the Creative Commons Attribution license (http://creativecommons.org/licenses/by/3.0/). 